\title{
THE FLOOD TOWER NETWORK A Warning System for St. Lawrence Riparians
}

By Rachel Rodd

\begin{abstract}
A thesis submitted to the Faculty of Graduate and Postdoctoral Affairs in partial fulfillment of the requirements for the degree of
\end{abstract}

Master

in

Architecture

Carleton University

Ottawa, Ontario

(C)2019

Rachel Rodd 


\section{ABSTRACT}

This thesis questions whether our dependence on the extensive river infrastructure of dams and spillways and leading edge communication technologies are sufficient means of community protection against flooding in an era of climate change and unpredictable floodplain development. Can architecture serve communities to promote a greater understanding of local rivers and raise an awareness for flooding while revealing the invisible - and often underestimated - forces of water around us?

A network of Flood Towers are proposed along the St. Lawrence and Ottawa Rivers. Subverting the legacy of prevailing water control infrastructure, these Towers stand as physical reminders of inundated villages of the past and serve as warnings to lost villages of the future. A House Moving network is proposed in partnership with the Towers to enable communities to rapidly withdraw their homes from the unstable landscapes. 


\section{ACKNOWLEDGEMENTS}

To my thesis advisor Sheryl for your continued guidance, encouraging words and library of knowledge.

To my current colleagues who not only generously provided me the flexibility to continue working throughout my graduate studies, but who shared their ideas, their passions and their optimisms in regards to my topic of study.

To everyone who have shown patience, support and guidance and who have shared moments of laughter and brightness throughout my years of architectural studies.

Thank you. 


\section{TABLE OF CONTENTS}

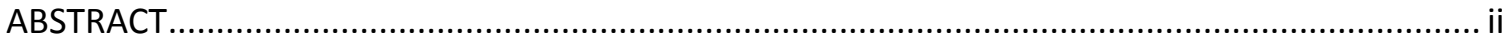

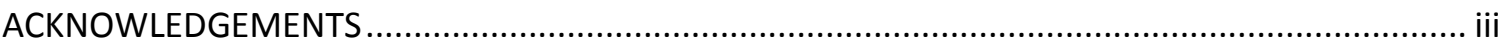

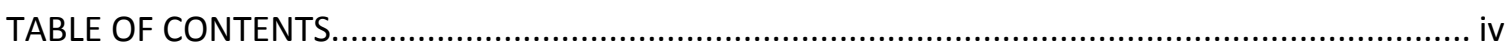

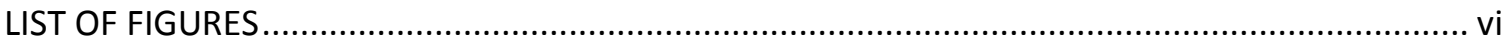

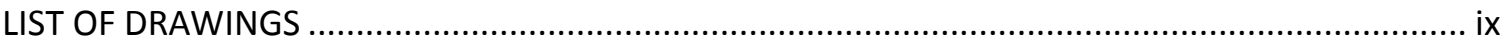

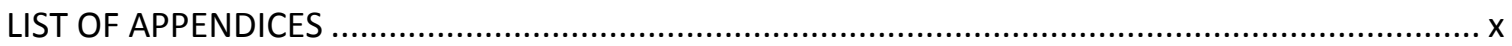

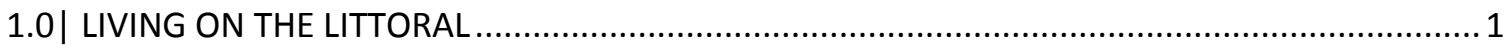

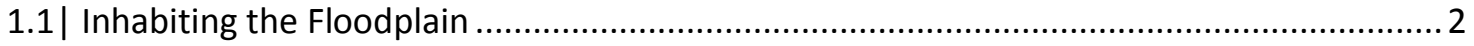

2.0

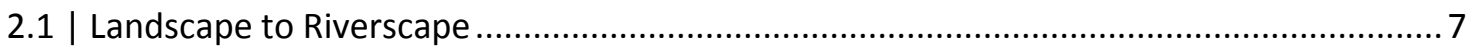

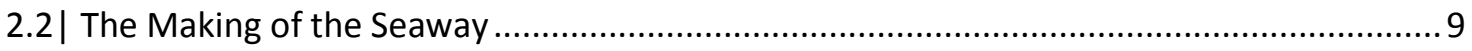

2.3 Inundation Day: The Story of the Lost Villages ........................................................... 12

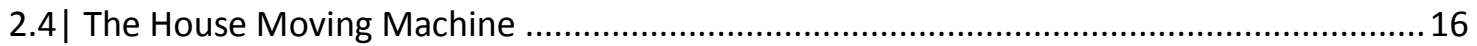

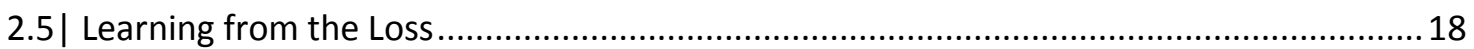

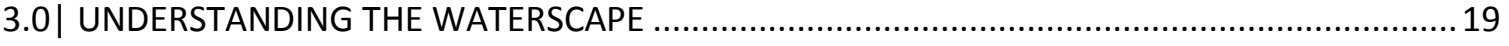

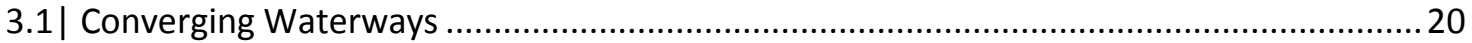

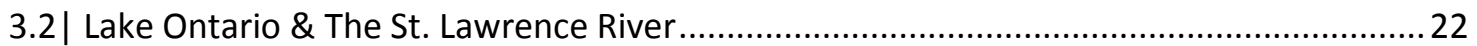

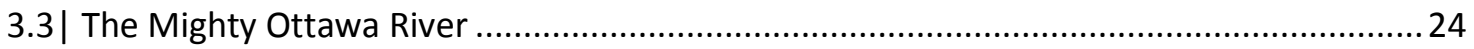

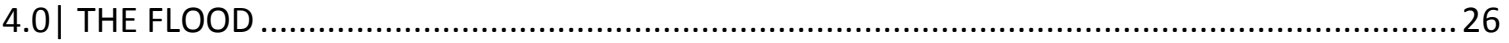

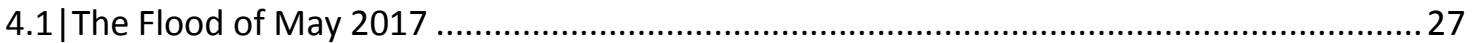

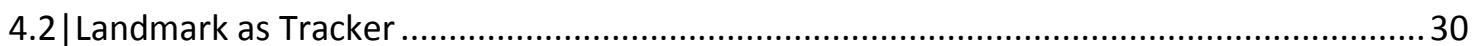

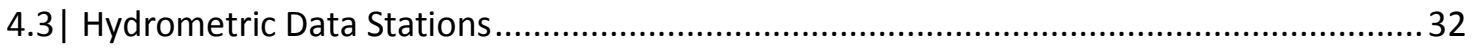

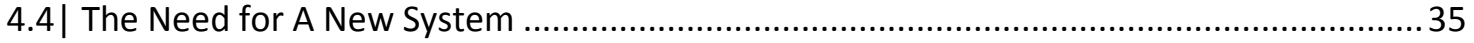

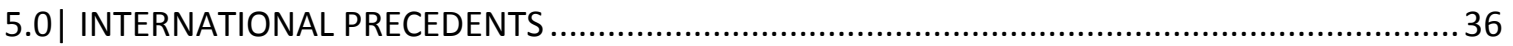

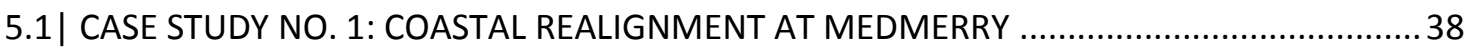

5.2 |CASE STUDY NO. 2: ROOM FOR THE WAAL RIVER ...................................................... 40

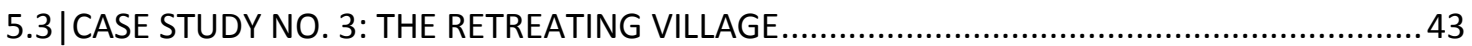

5.4 |CASE STUDY NO. 4: WHANGAPOUA - THE SLED HOUSE..................................................... 46 


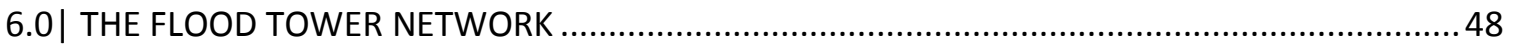

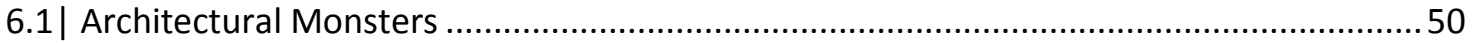

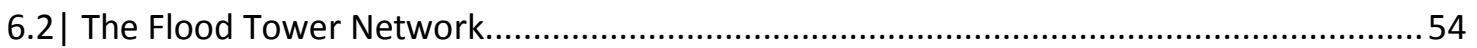

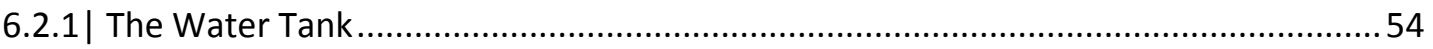

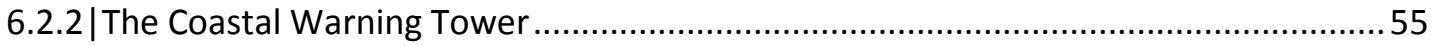

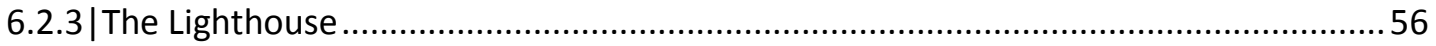

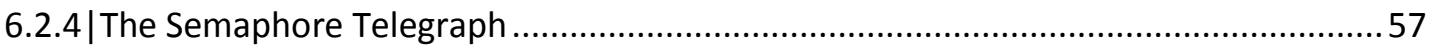

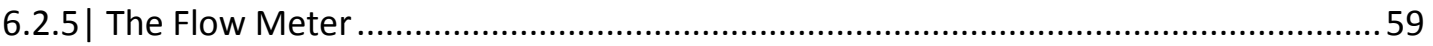

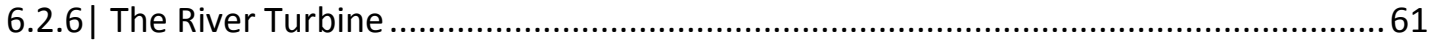

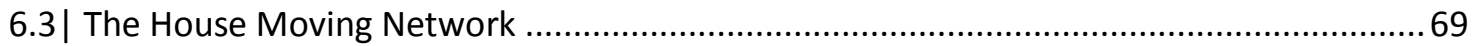

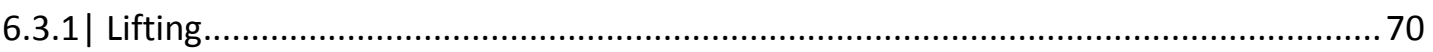

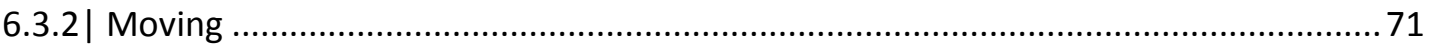

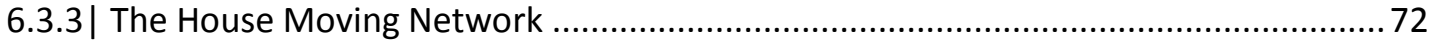

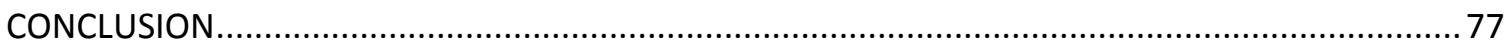

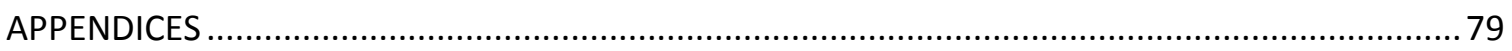

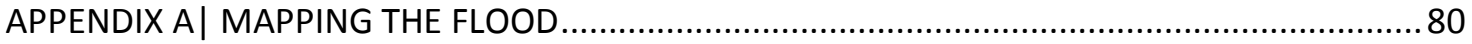

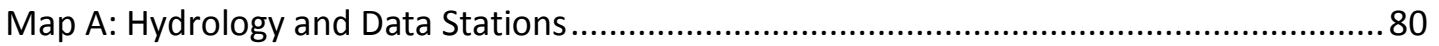

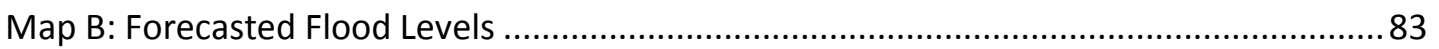

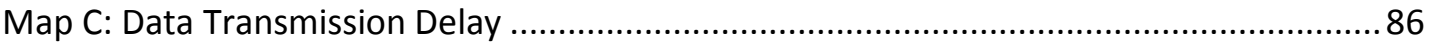

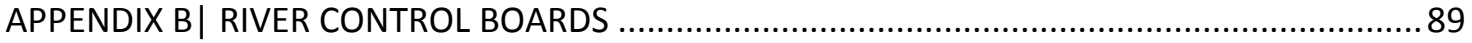

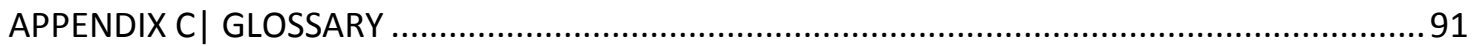

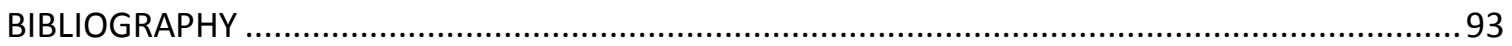




\section{LIST OF FIGURES}

Figure 1 | Section Through a Floodplain.

Source: accessed November 12, 2018 ,

https://www.maine.gov/dacf/flood/docs/handbook07/07-Chapter\%2002-Floodplain\%20Data.pdf

Figure 2 | Canadian soldiers inspect a flooded residential area in Gatineau, May 7, 2017..........4 Source: Chris Wattie, accessed March 19, 2019,

https://www.macleans.ca/news/canada/its-time-we-stopped-paying-for-your-river-view/

Figure 3 | Contemporary view of Seaway at Montreal, 2015

Source: John Gleed, accessed March 7, 2019,

http://stlawrencepiks.com/

Figure 4 | Overall view of the downstream end of the Seaway project June 15, 1958

Source: Power Authority of the State of New York, accessed November 11, 2018,

https://danielmacfarlane.wordpress.com/2013/10/

Figure 5 | Downtown Aultsville East to West.

Source: Louis Helbig, accessed March 10, 2019, http://sunkenvillages.ca

Figure 6 | Old Iroquois Lock 25.

Source: Louis Helbig, accessed March 10, 2019,

http://sunkenvillages.ca

Figure 7 | House on Hartshorne Moving House Machine called "The Tournamover"

after R.G. LeTourneau, 1958.

Source: Figure from Maggie Wheeler's personal archives (2014), Canadian Encyclopedia, accessed March 8, 2019,

https://www.thecanadianencyclopedia.ca/en/article/the-lost-villages

Figure 8 | The Ottawa River floods homes in Rigaud, Quebec, May 8, 2017

Source: CNN, accessed November 8, 2018,

https://www.cnn.com/2017/05/08/world/gallery/canada-flooding-0508/index.html

Figure 9 | The Ottawa River floods homes in Rigaud, Quebec, May 8, 2017.

Source: $\mathrm{CNN}$, accessed November 8, 2018 ,

https://www.cnn.com/2017/05/08/world/gallery/canada-flooding-0508/index.html

Figure 10 | Moses Saunders Power Dam, 1954 to 1958.

Source: John Gleed, Figures from St. Lawrence Piks, accessed March 30,2019,

http://stlawrencepiks.com/seawayhistory/seawayconstruction/cornwallmassena/index.html

Figure 11 | Barnhart Island Control Dam, 1954 to 1958.

Source: John Gleed, Figures from St. Lawrence Piks, accessed March 30,2019,

http://stlawrencepiks.com/seawayhistory/seawayconstruction/cornwallmassena/index.html

Figure 12 | The Carillon Generating Station is located about 19 kilometres from

Rigaud, one of the Quebec communities hardest hit by recent flooding, May 2017.

Source: CBC, accessed March 30, 2019,

https://www.cbc.ca/news/canada/montreal/ottawa-river-hydro-dams-doing-their-job-says-quebec-environment-minister-1.4105058

Figure 13 | A wave crests near the Chaudière Bridge on the Ottawa River on May 8, 2017.......26 Source: CBC, accessed March 30, 2019,

https://www.cbc.ca/news/canada/montreal/ottawa-river-hydro-dams-doing-their-job-says-quebec-environment-minister-1.4105058 
Figure 14 | Ile Mercier covered in floodwater is seen on the Riviere des Prairies on the north part of Montreal, May 8,2017.

Source: Paul Chiasson, accessed November 8, 2018,

https://globalnews.ca/news/3438421/quebec-floods-montreal-area-school-closures-for-wednesday-may-10/

Figure 15 | A resident of Mercier Island drains her house of floodwaters, May 9, 2017.

Source: CNN, accessed November 8, 2019,

https://www.cnn.com/2017/05/08/world/gallery/canada-flooding-0508/index.html

Figure 16 | Sketch Illustrating the Hydrology of Lake Ontario, 2017

Source: IJC, accessed March 30, 2019, https://www.mcgill.ca/h2oinnovation/files/h2oinnovation/2017floods_analysis.pdf

Figure 17 | Trail River staff gauge on old river pier.

Source: National Weather Service Advanced Hydrological Prediction Service, accessed March 30, 2019,

https://water.weather.gov/ahps2/hydrograph.php?wfo=pafc\&gage=mpta2

Figure 18 | Locations of the main hydrometric stations along the fluvial portion of the system and its main tributaries.

Source: Accessed March 9, 2019, http://planstlaurent.qc.ca/en/state_monitoring

Figure 19 | Hydrometric Station at Lanoraie.

Source: Environment Canada, accessed March 9, 2019, http://planstlaurent.qc.ca/en/state_monitoring

Figure 20 | Coastal Realignment at Medmerry, 2014.

Source: Accessed November 18, 2018, https://oppla.eu/casestudy/18379

Figure 21 | Room for the River Master Plan, 2018

Source: Accessed November 18, 2018, https://www.ruimtevoorderivier.nl

Figure 22 | Room for the River Nijmegen Before, 2018

Source: $\mathrm{H}+\mathrm{N}+\mathrm{S}$ Landscape Architects, accessed November 18, 2018,

http://www.landezine.com/index.php/2016/08/room-for-the-river-nijmegen-by-hns-landscape-architects/

Figure 23 | Room for the River Nijmegen After, 2018.

Source: $\mathrm{H}+\mathrm{N}+\mathrm{S}$ Landscape Architects, accessed November 18, 2018,

http://www.landezine.com/index.php/2016/08/room-for-the-river-nijmegen-by-hns-landscape-architects/

Figure 24 | The village is shown its inevitable withdrawal from the edge, 2005

Source: Laura Allen, Retreating Village, Image 19, pg. 17

Figure 25| The Sled House, 2012

Source: Crosson Architects, accessed March 30,2019, http://crosson.co.nz/hut-on-sleds-whangapoua/

Figure 26 | Beauharnois, Quebec Municipal Water Tower.

Source: Accessed March 7, 2019, https://www.tripmondo.com/canada/quebec/monteregie/beauharnois/

Figure 27 | Coastal warning display tower from 1898, New Haven CT.

Source: Jeremy D'Entremont, , Ibiblio accessed March 5, 2019,

https://www.ibiblio.org/lighthouse/storm_warning_towers.htm 
Figure 28 | Storm Signal Diagram, 1898.

Figure 29 | John Smeaton's rebuilt version of the Eddystone Lighthouse, 1759. Source: Accessed March 7, 2019, http://www/wilson-benesch.com/newsblog.html

Figure 30 | Lighthouse Lenses, 1759

Source: Figure in Adolphe Ganot, Natural Philosophy for General Readers and Young Persons, (New York: D. Appleton \& Co., 1872) p.329, fig. 258.

Figure 31 | The Chappe Telegraph System, 1792

Source: accessed March 7, 2019, http://www.telegraphe-chappe.com/chappe/resume.html

Figure 32 | A London - Portsmouth semaphore station, 1825

Source: Figure in Ken Beachamp, History of Telegraphy, (London: The Institution of Engineering and Technology, 2001), pg.11, fig. 1.5.

Figure 33 | Components of a Variable Area Flowmeter

Source: The Teco Process Control Blog, accessed March 8, 2019,

https://blog.teco-inc.com/search?updated-max=2017-01-30T20:40:00-08:00\&max-results=7\&reverse-paginate=true

Figure 34 | Pelton Wheel, October 1880

Source: L. A. Pelton, Figure from Pelton's original paten, US Patent 233692, pg.1

Figure 35 | Foundation Cribbing, St. Joseph, 2015

Source: Wolfe House Building Movers, accessed March 30, 2019, https://www.wolfehousebuildingmovers.com/project/

Figure 36 |House Relocation, St. Joseph, MI, July MI, July 2015

Source: Wolfe House Building Movers, accessed March 30, 2019, https://www.wolfehousebuildingmovers.com/project/

Figure 37 | Hartshorne House Mover, 1958

Source: Figure from Life Magazine, posted in American Truck Historical Society General Archives: What am I, posted March 7, 2011, http://forums.aths.org/PrintTopic111979.aspx

Figure 38 |Hydraulic Dolly Underneath Relocated Foundation

Source: Wolfe House Building Movers, accessed March 30, 2019, https://www.wolfehousebuildingmovers.com

Figure 39 |Hydraulic Dollies

Source: Wolfe House Building Movers, accessed March 30, 2019, https://www.wolfehousebuildingmovers.com 


\section{LIST OF DRAWINGS}

Drawing 1 | Mapping of the Lost Villages Relocation 1958

Rachel Rodd 2019

Drawing 2 | Postcards as Tribute to the "Lost Villages"

Rachel Rodd 2019

Drawing 3 | Water Tower: View from Pedestrian Bridge. .53 Rachel Rodd 2019

Drawing 4 | Water Tower - Perspective from the Viewing Platform

Rachel Rodd 2019

Drawing 5 | Water Tower - Perspective from the Entrance Dock. 64 Rachel Rodd 2019

Drawing 6 | Water Tower - View of River Turbines from Underwater.

Rachel Rodd 2019

Drawing 7 | Water Tower - Plan.

Drawing 8 | Water Tower - Longitudinal Section.

Rachel Rodd 2019

Drawing 9 | River Site Model - Epoxy Resin on Spalted Maple

Drawing 10 | House Moving Network - Plan.

Rachel Rodd 2019

Drawing 11 | House Moving Network - Track Assembly.

Rachel Rodd 2019

Drawing 12 | House Moving Network - Tractor Pulley System.

Drawing 13 | Map A - Hydrology \& Data Stations

Rachel Rodd 2019

Drawing 14 | Map B - Forecasted Flood Levels.

Drawing 15 | Map C - Data Transmission Delay 


\section{LIST OF APPENDICES}

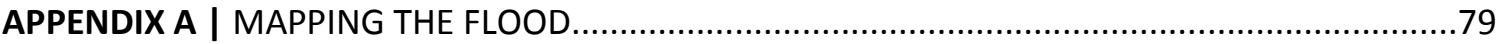

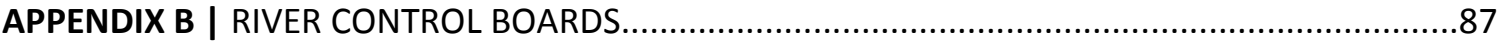

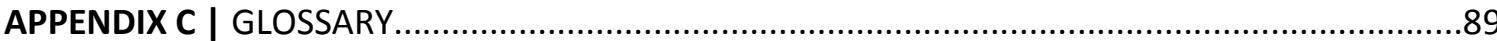




\subsection{LIVING ON THE LITTORAL}

Of all grounds [water] is the most insubstantial because it has no particular identity, no fixed position(s), and if anything, the sea severs the will to identify and tends to multiply and confuse the specificity of location.(Yates, 69) 


\section{1| Inhabiting the Floodplain}

Littoral properties have drawn communities to their edges for centuries. In the past, residing in proximity to water meant stable access to an abundant food source, a means of transportation, and the eventual ability to harness its forces for energy consumption. Despite the associated risks of flooding, people continue to establish their homes along waterfront sites due to their proximity to nature and increased property value. As interest in littoral development within floodplains increases, the riparian damage caused by flooding subsequently continues to increase. Regardless of whether floodwaters occupy the floodplain for a matter of minutes, hours or months, the damage to property and infrastructure is calamitous and often insurmountable. Prime conditions for the actualization of flood events are met regularly in the Canadian climate. The most severe flooding events result from the "compounding influences of two or more causes, such as heavy rainfall together with the spring snowmelt runoff."1 ${ }^{11}$ From coastal storms, ice jams, rainstorms and tsunamis, flooding is ranked as one of the most damaging natural disasters in the world. ${ }^{2}$ Flooding plays both an essential role in maintaining healthy ecosystems and coastal environments, while presenting itself as a hazard to communities established adjacent to water.

\footnotetext{
1 "Floods: General Information," Government of Canada, Last modified December 2, 2010, https://www.canada.ca/en/environment-climate-change/services/wateroverview/quantity/floods/general-information.

2 "General Information," Government of Canada.
} 
Dikes have been trenched, canals have been dredged, dams have been built, and although these measures have been partially beneficial to flood alleviation in the past, these built infrastructures encourage communal encroachment along the floodplain. Water in a floodplain flows quickly and unpredictably, relentlessly destructive to anything in its path of travel. When stream channels no longer have the capacity to store flows within their normal limits, water spills over its banks and into the adjacent land.

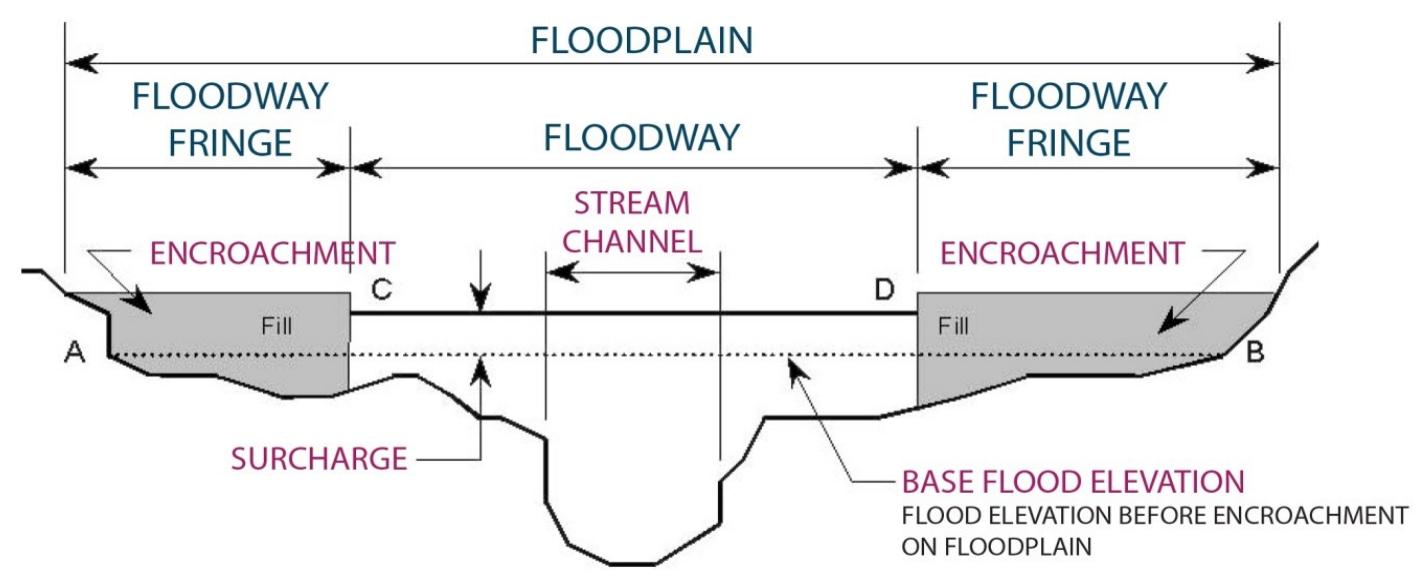

LINE A-B IS THE FLOOD ELEVATION BEFORE ENCROACHMENT LINE C-D IS THE FLOOD ELEVATION AFTER ENCROACHMENT

Figure 1 | Section Through a Floodplain

Source: accessed November 12, 2018, https://www.maine.gov/dacf/flood/docs/handbook07/07-Chapter\%2002-Floodplain\%20Data.pdf

Notwithstanding the risk of vulnerability that comes with building in a floodway, inhabitants are continuously beguiled by the benefits that are offered by waterfront properties. Floodplains are dynamic and ever-changing ${ }^{3}$; architectural foundations built within these plains are often fixed and immobile, exposing them

\footnotetext{
${ }^{3}$ Floodplain: Flat land beside a lake or river, susceptible to flooding if any overflow occurs; part of a water's living space. Floodways are zones within a floodplain where floods are most destructive and the water flows fastest.
} 
to the destructive nature of water. Communities — who are often ignorant or simply uneducated on the reality of river hydrology — heavily depend on the massive river infrastructure of dams and spillways to provide them with sufficient protection. This thesis considers how architecture might be used to promote community engagement with rivers and waterways by making the dangerous and fluctuating nature of water recognizable to all.

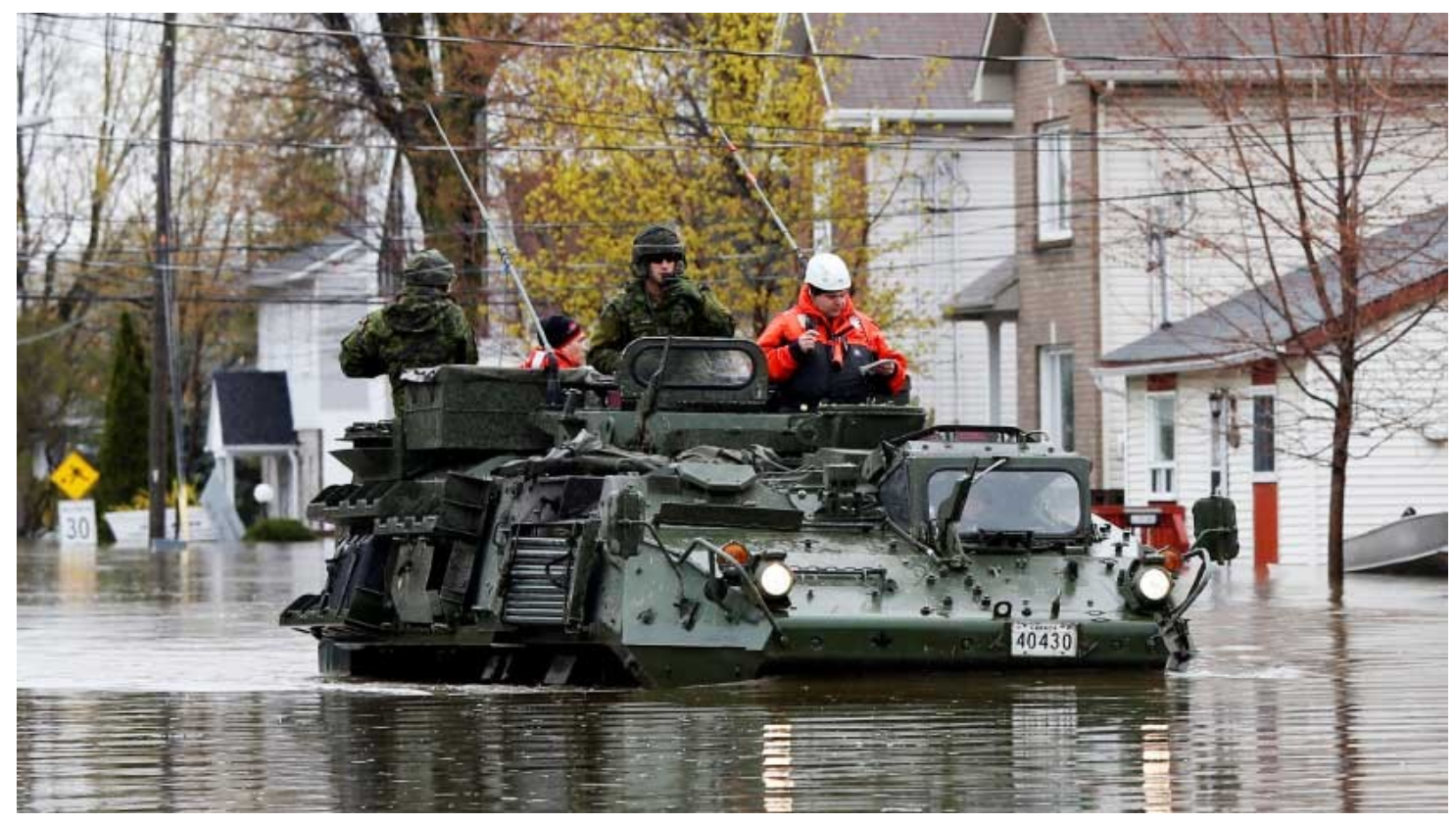

Figure 2 | Canadian soldiers inspect a flooded residential area in Gatineau, May 7, 2017 Source: Chris Wattie, accessed March 19, 2019, https://www.macleans.ca/news/canada/its-time-we-stopped-paying-for-your-river-view/

Although civilians who reside in floodplains are ostensibly aware that there is a sizeable chance their property will flood they continue to remain regardless of the associated risks. The Canadian government has attempted to alleviate the impact of flooding through the construction of protective dykes, the creation of upstream storage on their waterways, and through the provision of emergency aid 
and disaster assistance. ${ }^{4}$ Despite the benefits associated with the measures listed above, they negate these benefits by encouraging sustained settlement growth within floodplains. "As the memory of past [flooding] events recede, there is a tendency to ignore the maintenance of existing control works, and to allow new development upstream, increasing the likelihood of flood damage." ${ }^{5}$ This continued encroachment thus increases the potential for flood and leads to the necessity for greater levels of flood protection. At a certain point, there is only so much that structural prevention methods can do to provide a solution to reducing the impact of flooding. We must look to other means of preparing for the encroachment of water within our communities.

4 "General Information," Government of Canada.

5 "Flooding FAQ," Ottawa River Regulation Planning Board, http://www.ottawariver.ca/flooding-faq.php 


\section{0| LOST \& FOUND}

The River only smiled that morning and went about its spring business of breaking the winter's ice, for it knew men would never tame it. They might use it, grasp a little of its power for themselves, build cities at its sides, and launch their ships upon its current, but nothing could alter by more than a few yards the irresistible current of the St. Lawrence or curb its yearning toward the sea. (Hutchinson, 130) 


\section{1 | Landscape to Riverscape}

This thesis will begin by analyzing events from July 1, 1958 during the construction of the St. Lawrence Seaway and Power Project where nine riparian communities, known as the "Lost Villages", were comprehensively inundated along the St. Lawrence River. The making of the St. Lawrence Power Project is an example of an artificial, man-made flooding event that changed an inhabited landscape into a submerged riverscape. The project contrived a fabricated floodplain that wiped out entire communities who were at the mercy of covetous industrialists eager to tame the river and harness its power for hydroelectricity. Regardless of the means, the ends resulted in the displacement of entire communities who had little warning that the flood waters were coming. Although technically an artificial flood, the inundation of the "Lost Villages" can be treated as a reminder and can shed recognition on floodwater's ability to cause catastrophic loss. We must not contest that we are often powerless against the strength of water. 


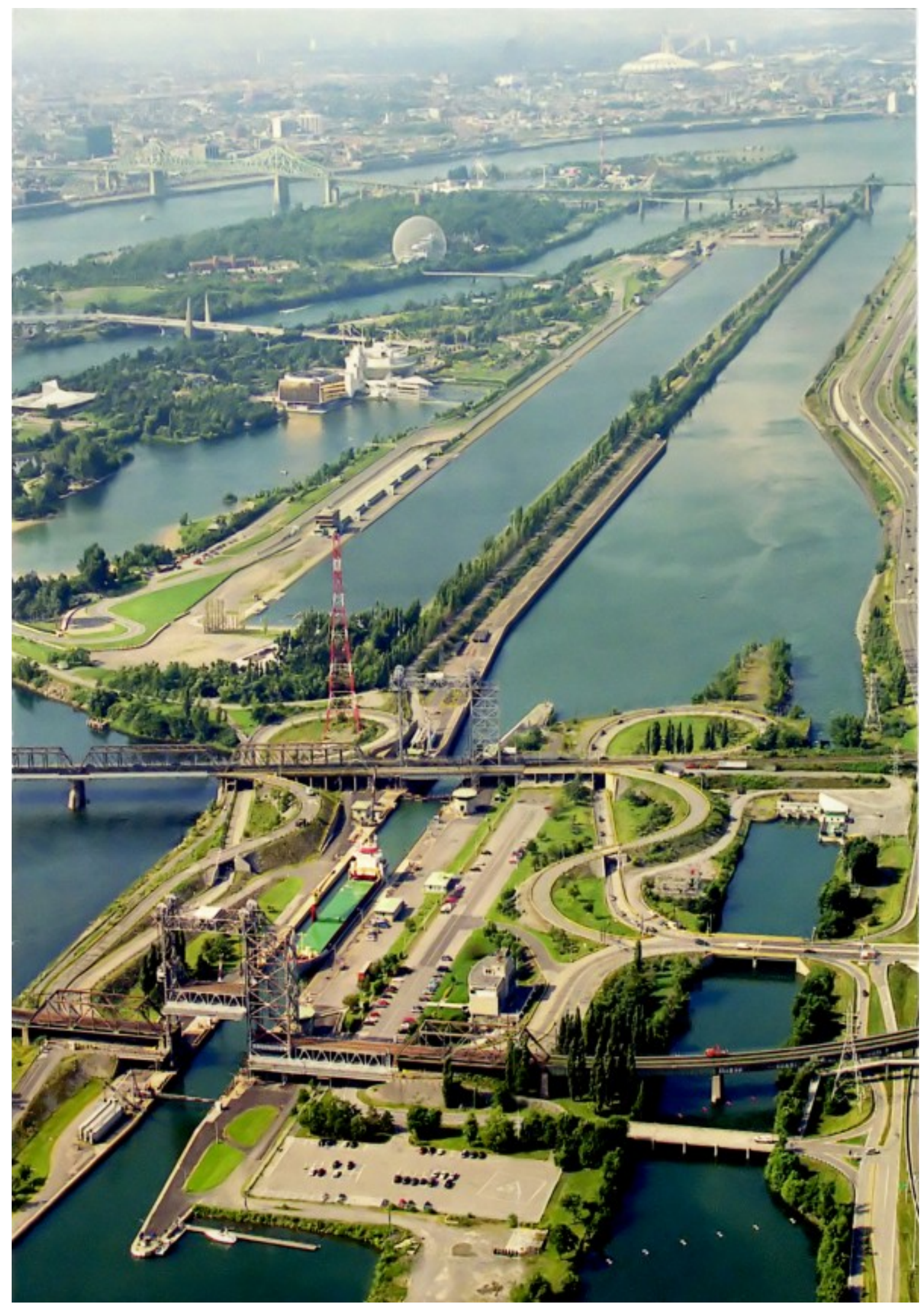

Figure 3 | Contemporary view of Seaway at Montreal, 2015

Source: John Gleed, accessed March 7, 2019, http://stlawrencepiks.com/ 


\section{2| The Making of the Seaway}

The Saint Lawrence Seaway is a man-made, joint venture between the Canadian and American governments that was superimposed over the St.

Lawrence River. The engineered development incorporated a series of navigation works including channels, dams, and canals that run 291 kilometers from Montreal to Lake Erie. The dredging of the St. Lawrence Seaway allowed for the passage of marine vessels from the Atlantic Ocean to the North American Great Lakes, stretching as far as the western edges of Lake Superior. "[The Seaway Project] turned the St. Lawrence into a hybrid waterscape that blended the mechanical and the organic, with hydro dams and locks the means by which the river could be perfected and its waters utilized." ${ }^{6}$ Monumental, man-made structures —-the scale of which most locals had never experienced — were being erected all along their waterfront, forever changing the skyline of the communities they once knew. One such structure, the Moses-Saunders Power Dam was one of the largest control structures along the seaway and provided hydroelectric power to both the Canadian and American communities in its vicinity. The increased water levels at the location of the dam resulted in a head pond known as Lake St. Lawrence, a 100 square mile reservoir, approximately thirty-four miles long. The lake formed a new body of water that flooded out the surrounding area, dramatically pushing back

\footnotetext{
${ }^{6}$ Richard White, The Organic Machine: The Remaking of the Columbia River, (New York: Hill and Wang, 1995), as quoted by Daniel McFarlane in Negotiating a River.
} 
the shoreline of these once established communities. " "They have cut channels, removed islands, filled in points of access, laid down roads, set up bridges [and] relocated everything from telegraph poles to towns. ${ }^{18}$ It was determined that all land up to a contour of 250 feet above sea level along the shoreline from Cornwall to Prescott would be claimed as a buffer zone to accommodate changed water levels. ${ }^{9}$ The excavated soil was dumped along the banks of the waterway, culminating in prominent changes to the surrounding landscape.

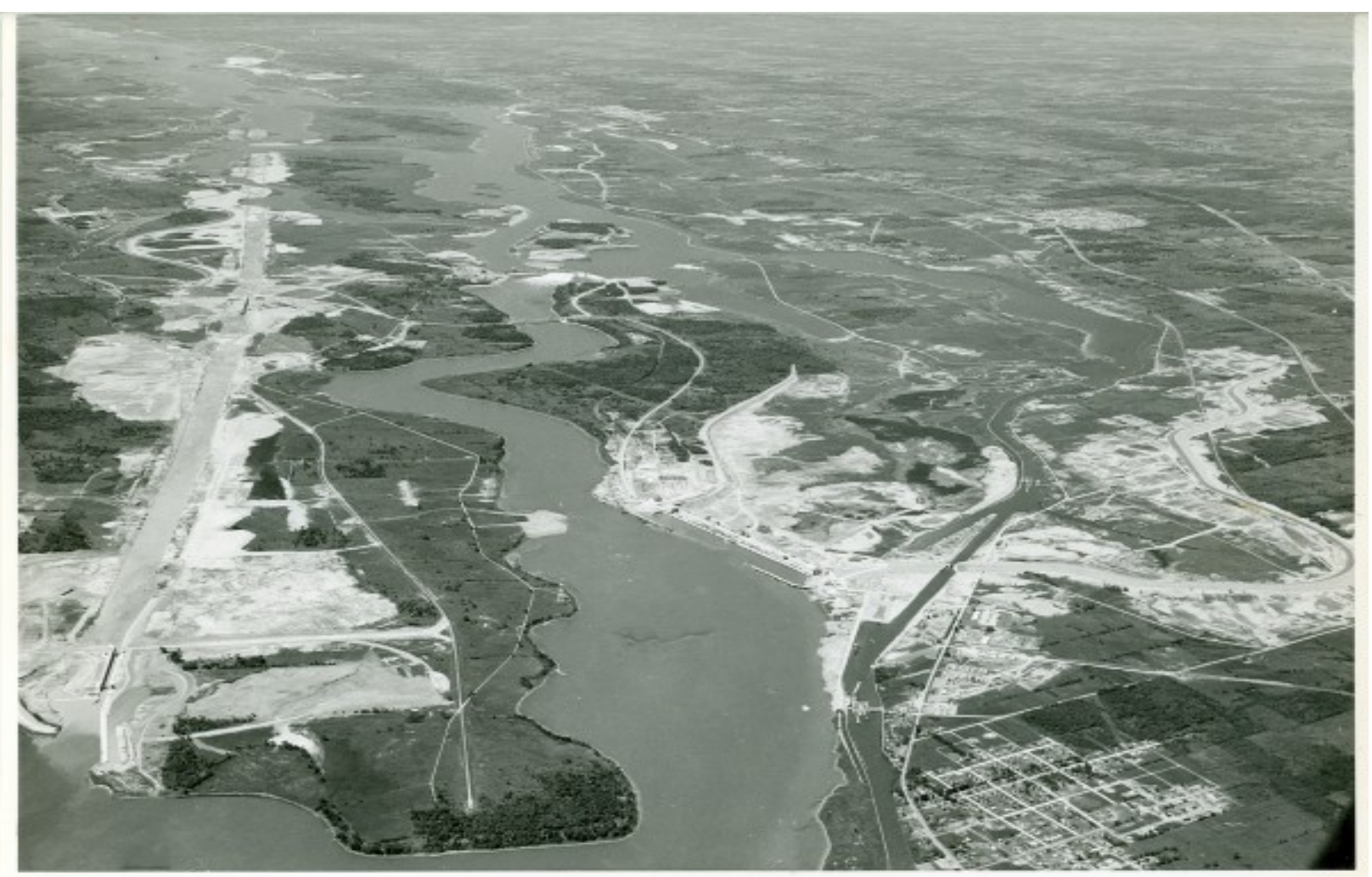

$7169 \mathrm{G}$ - Overall view of the downstream end of the profect showing the St. Lawrence Power Dare at right center and the two locks and Seaway Canal at left. POWER AUTHORITY OF THE STATE OF NEW FORK

Figure 4 | Overall view of the downstream end of the Seaway project, June 15, 1958 Source: Power Authority of the State of New York, accessed November 11, 2018, https://danielmacfarlane.wordpress.com/2013/10/

\footnotetext{
${ }^{7}$ McFarlane, Negotiating a River, 6.

${ }^{8}$ Lowell J. Thomas, The Story of the St. Lawrence Seaway (Buffalo, New York: Stewart, 1957), 13.

${ }^{9}$ McFarlane, Negotiating a River, 158.
} 

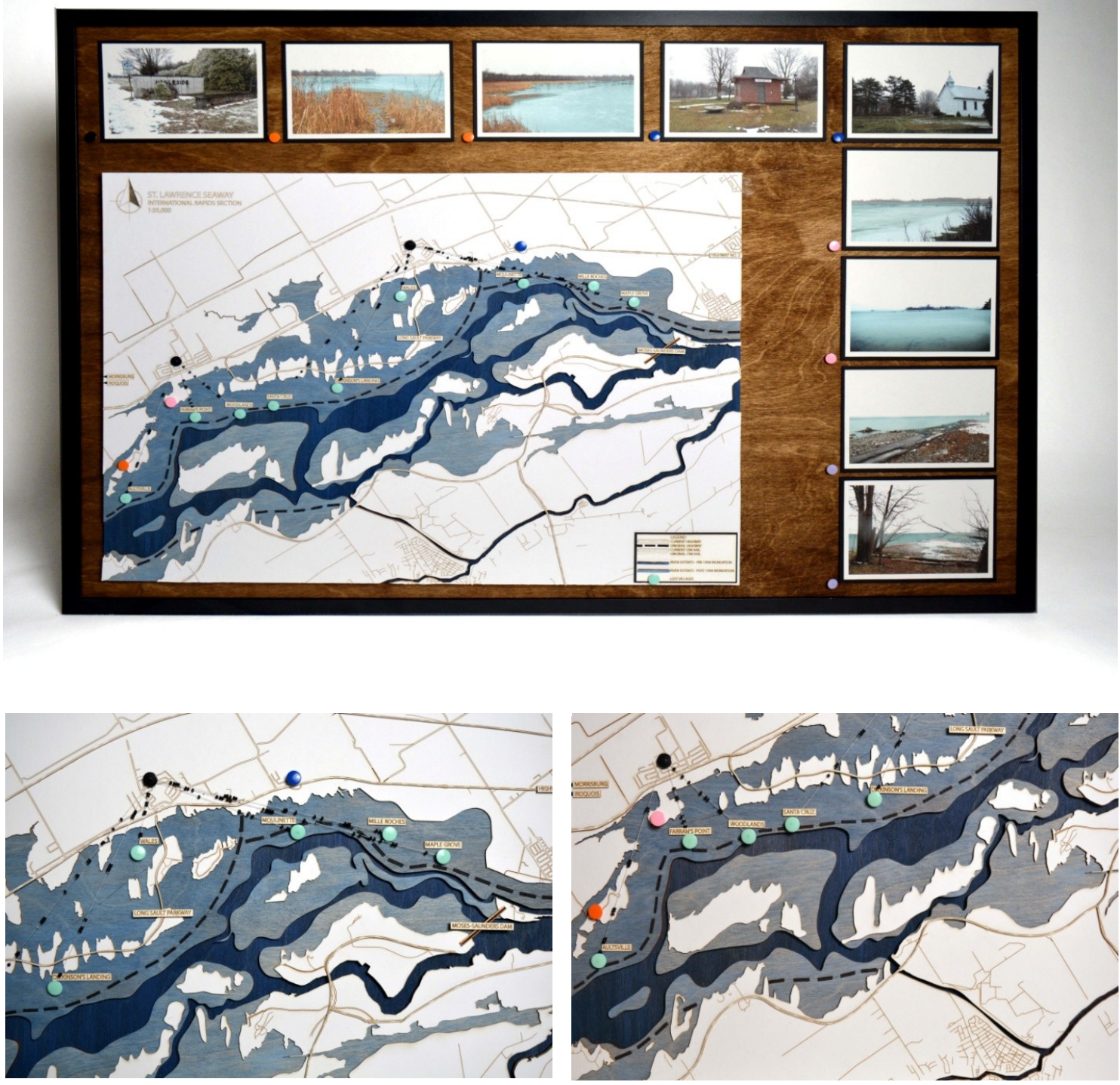

Drawing 1 | Mapping of the Lost Villages Relocation 1958

Above is a laser cut model of a portion of the St. Lawrence River upstream of the Moses-Saunders Power Dam between Morrisburg, Ontario and Cornwall, Ontario. The map features the drastic change of the river extents prior to and after the flooding of the Seaway in 1958. Originally sited on the edge of the river, all nine "Lost Villages" can be seen submerged underneath the extents of the new floodwaters. 


\section{3| Inundation Day: The Story of the Lost Villages}

For several small communities in Ontario, July 1st 1958 will forever be remembered as Inundation Day, marking the date in Canadian history in which nine communities were inundated under flood waters as a result of the creation of the St. Lawrence Seaway and Power Project . ${ }^{10}$ "The flooding was initiated at 8:o1a.m. when thirty tons of explosives ripped through cofferdam A-1, a 6oo-foot artificial dam between Sheek and Barnhart Islands."'11 The loss of the nine communities along the edge of the Seaway "portrayed, at the time, as triumph rather than tragedy, or at least as a small price to pay for the benefits in store."12 The project was viewed by many as a representation of progress and technology, although this opinion was not entirely shared by the residents of the sacrificial communities.

For a young lad, it was exciting times. For the elderly though, very sad and depressing times, because these are the folks that knew they could never go back."13 - Jim Brownwell, former Lost Village resident.

The families that lived among the nine Lost Villages had valued their connection to the river's edge and their way of life. These families had little warning that the

\footnotetext{
${ }^{10}$ Daniel McFarlane, Negotiating a River: Canada, the US, and the Creation of the St. Lawrence Seaway, Vancouver: UBC Press, 2014, 5.

${ }^{11}$ McFarlane, Negotiating a River, 179.

${ }^{12}$ McFarlane, Negotiating a River, Prologue XV.

${ }^{13}$ Paul Soucy, "Lost Villages of the St. Lawrence River: Canada's Atlantis," Global News, published August 8, 2018, https://globalnews.ca/news/4369620/lost-villages-of-the-st-lawrence-river-canadas-atlantis/
} 
floodwaters were coming and little say in regards to their uprooting; many families were left with lasting emotional grief. The St. Lawrence Seaway and Power Project was one of the largest rehabilitation projects in Canadian history. The complete relocation of entire communities and their corresponding infrastructure would prove to be no easy task. Over 20,00o acres of land was flooded out, resulting in the resettlement of over 6,500 people living between Iroquois and Cornwall, Ontario. Two new communities were being planned just north of the project flood-line to house the amalgamated populations of the Lost Villages. After the floodwaters were released on Inundation Day, the built environment that once sat on the edge of the St. Lawrence could no longer be recognized.

Residents could take a last stroll down their old street or pick out landmarks, if they could recognize them on the decimated landscape, as the water slowly crept up, agonizingly swallowing what already seemed a past life. (McFarlane, 167)

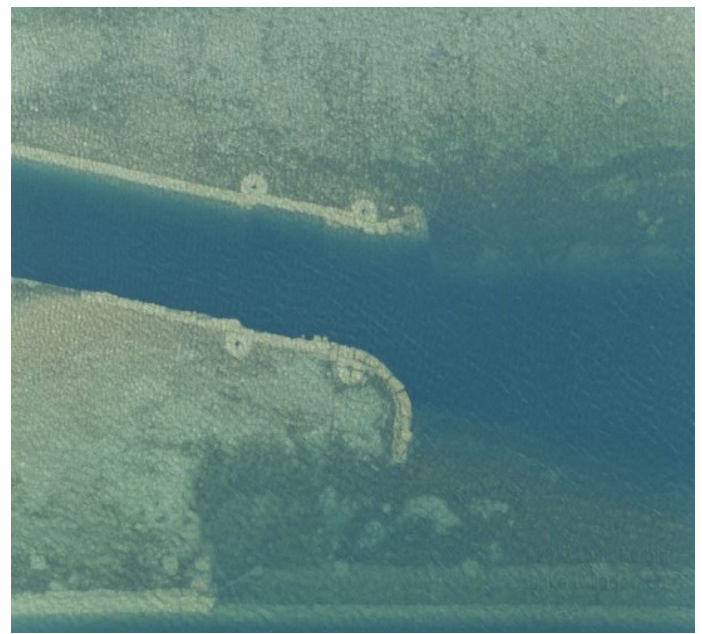

Figure 5 | Downtown Aultsville East to West Source: Louis Helbig, accessed March 10, 2019, http://sunkenvillages.ca

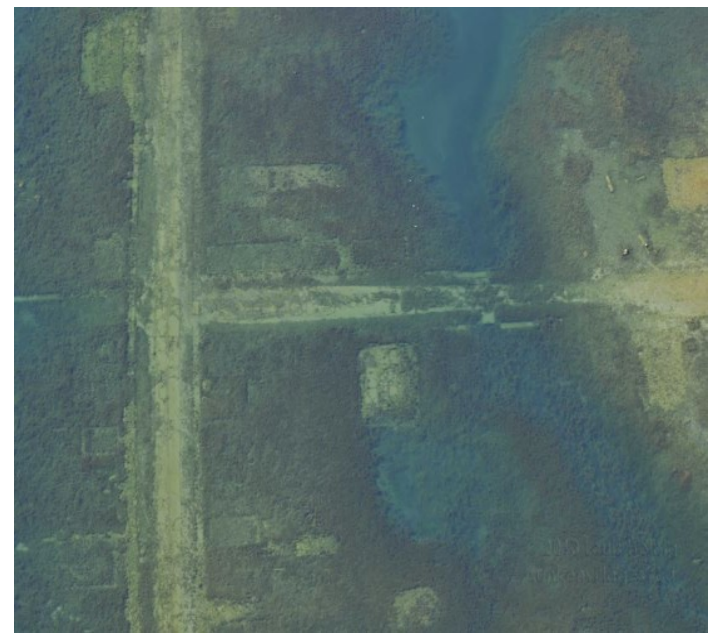

Figure 6 | Old Iroquois Lock 25

Above are aerial photographs captured by photographer Louis Helbig featuring the remains of concrete infrastructure beneath the floodwaters on the fringe of the St. Lawrence Seaway. 
The landscape had been stripped bare of its built environment. A step toward modernity for city planners and hydro plants meant a step further away from normalcy and routine for the displaced populates.

Identity [for the lost villagers] became equated with lost place and sense of attachment to the disappeared landscape ... The transmutation of landscape to riverscape in the Seaway Valley is an iconic narrative that tells a story about place and its various representations at particular moments in time. (O'Flaherty, 8) 

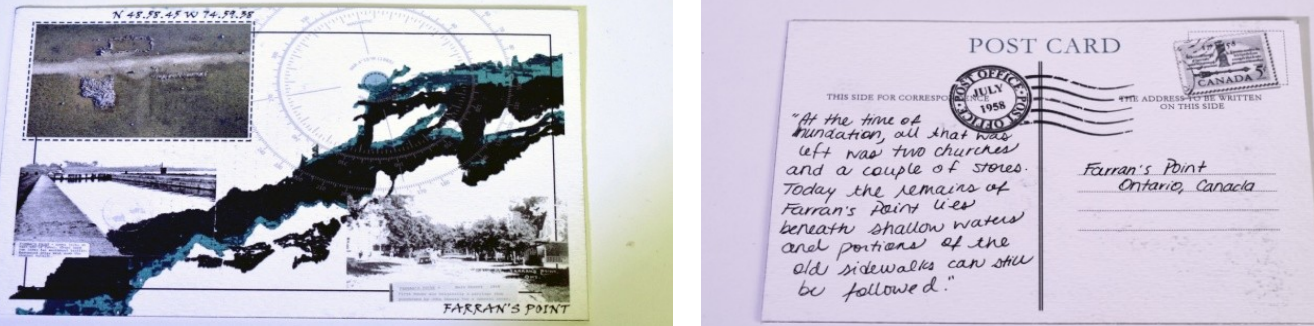

Farran's Point | "At the time of inundation, all that was left was a few churches and a couple of stores. Today the remains of Farran's Point lies beneath shallow waters and portions of the old sidewalks can still be followed."14
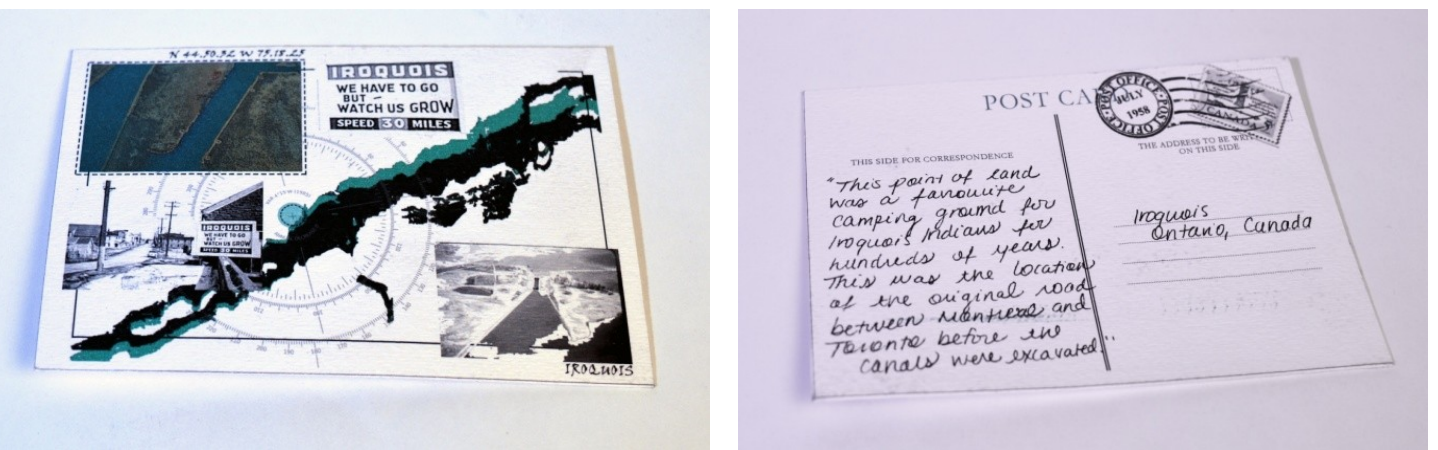

Iroquois | "This point of land was a favorite camping ground for Iroquois Indians for hundreds of years. This was the location of the original road between Montreal and Toronto before the canals were excavated."15

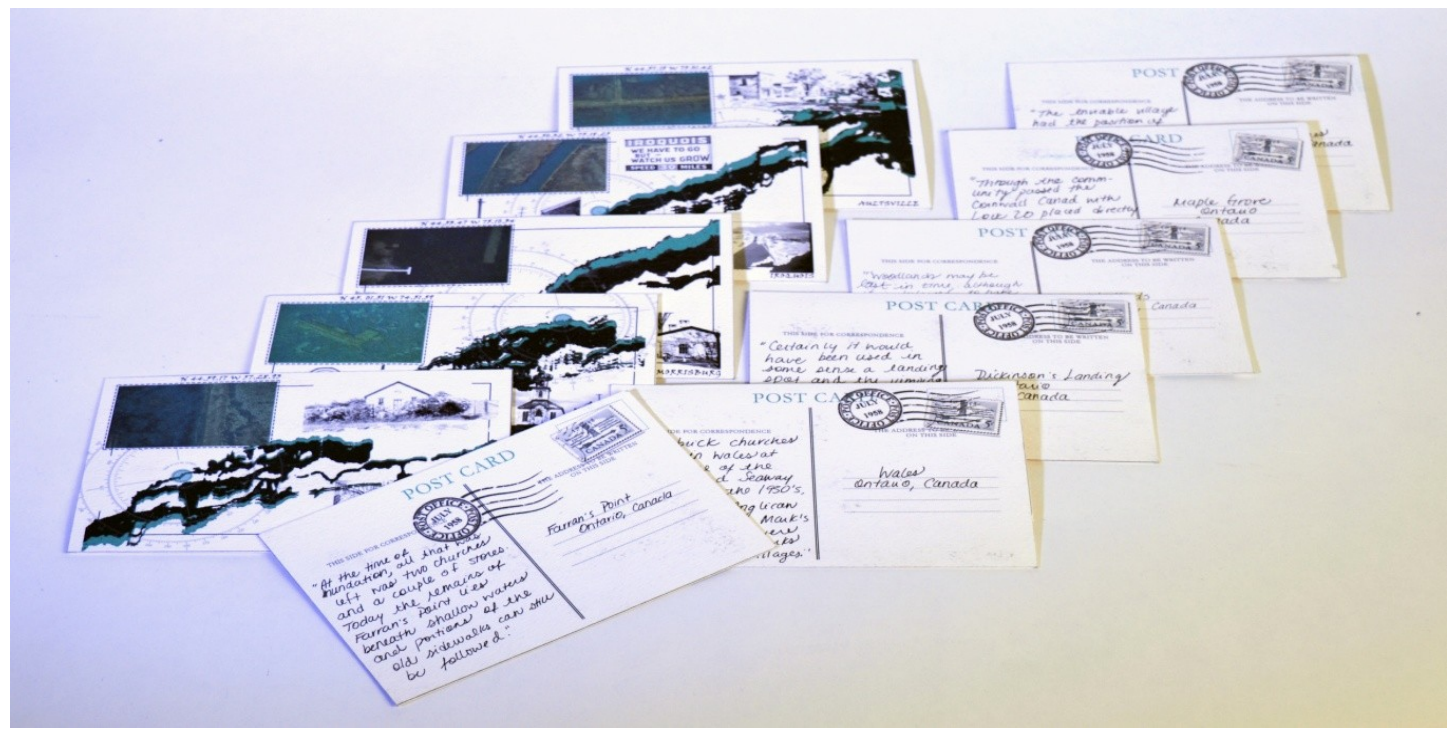

Drawing 2 | Postcards as Tribute to the "Lost Villages"

Above are a series of postcards created as "tribute" to each of the "Lost Villages" to serve as a reminder that their history has not gone unforgotten. Although the Seaway floodwaters have forever wiped away their neighbourhoods, the memory of their relocation will forever carry on.

\footnotetext{
14 "Lost Villages." The Lost Villages Historical Society. https://lostvillages.ca

${ }^{15}$ Ibid.
} 


\section{4| The House Moving Machine}

During the early stages of the project timeline, Ontario Hydro presented two options to property owners whose land would be lost in the flood zone. Homeowners could choose to receive market value of their homes or could opt to receive new replacement homes being built in one of the new communities. Some residents rejected the proposal to receive new homes as they found the new town designs too common for their liking. Ontario Hydro then explored the option of physically moving their homes to new lots of land. Due to the size and multiplicity of the Lost Villages relocation, large-scale machinery capable of moving houses was being used for the first time in Canada. Power shovels, draglines, earth movers and land scrapers were among some of the equipment used, but the most notable piece of equipment in their tool kit was the Hartshorne house-moving machine. ${ }^{16}$ The Hartshorne house-moving machine "could move a house sixty-five-feet long by approximately thirty-six-feet wide, carrying a load of up to 150 tons at a speed of six miles an hour."17 The scale and potential for a single machine to so easily uproot houses and transport them miles away was a staggering concept for those whose lives were being displaced.

\footnotetext{
16 "With this outsize contraption, called the Tournamover, one man can pick up a house and set it down in a new location in record time. The wheelbase of the four-wheeled tractor-trailer is 38 feet; the over-all length 50 feet, eight inches. The total weight is 31 tons. An electric power system, supplied by the tractor's 180-hp. diesel engine, is necessary to operate the mover. Motors hoist a house onto the trailer and level it. Another motor is required to steer the tractor on account of the huge weight of the machine and its load. The manufacturer is R. G. LeTourneau, Inc., Peoria, III."

${ }^{17}$ McFarlane, Negotiating a River, 156.
} 


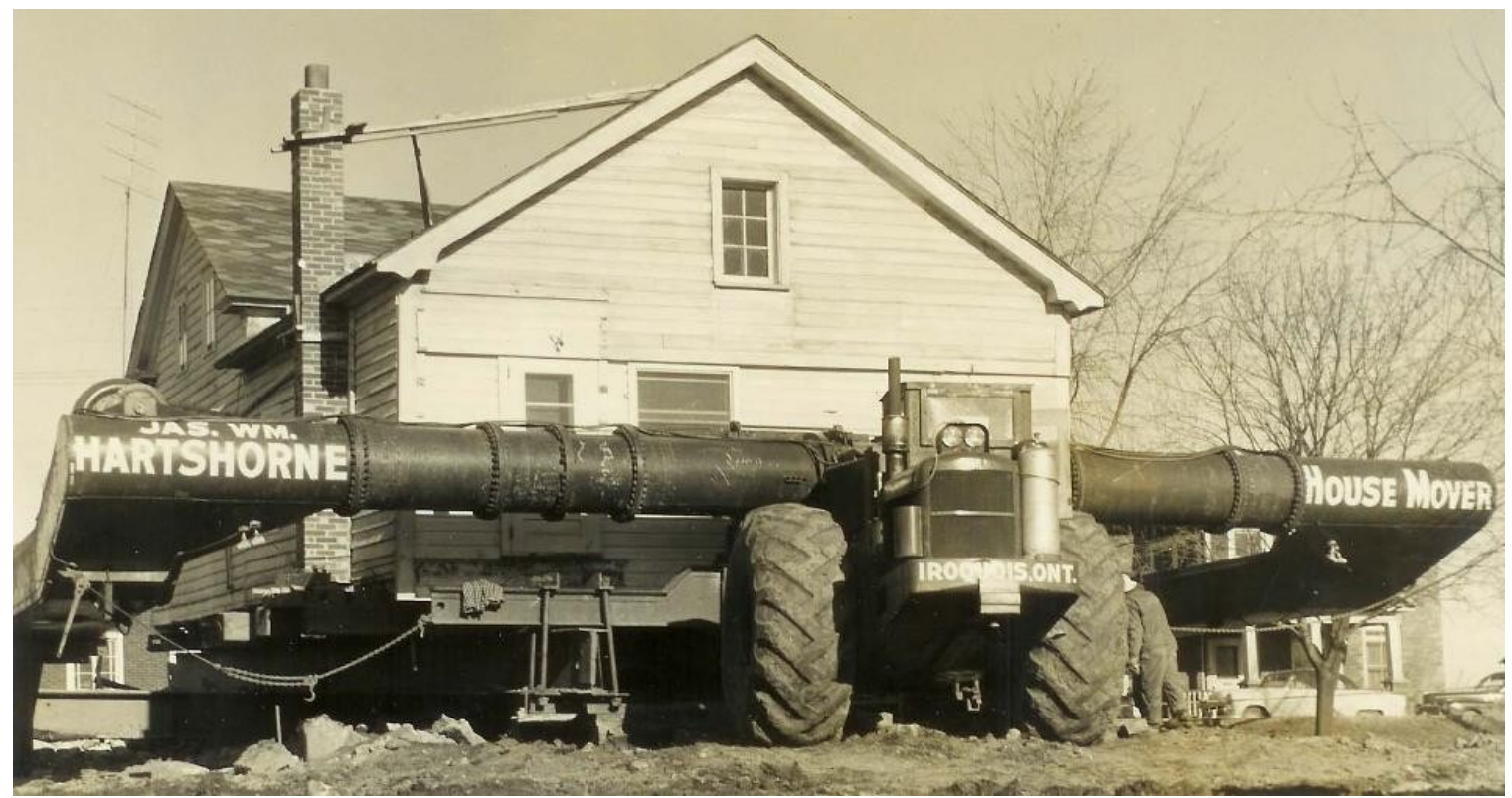

Figure 7 | House on Hartshorne Moving House Machine called "The Tournamover" after R.G. LeTourneau, 1958

Source: Figure from Maggie Wheeler's personal archives (2014), Canadian Encyclopedia, accessed March 8, 2019, https://www.thecanadianencyclopedia.ca/en/article/the-lost-villages

The movers lifted houses off their foundations by inserting metal beams into holes drilled into the house foundation; the building was then placed on a mobile house float equipped with ten-foot wheels and driven slowly to its new location. (McFarlane 155)

The concept of what it meant to be mobile was changing as inhabitants watched their belongings, their homes and their entire communities being completely relocated. Although a manufactured flood —an event that was carefully planned and calculated - the villagers on the periphery of the flood zone had little warning the waters coming. Sited on this waterfront landscape - a littoral landscape that is unpredictable, erratic and ever-changing - they were forced to retreat from the impending waters; their relocation made possible by the introduction of these nomadic machines. 


\section{5| Learning from the Loss}

Flooding is a temporal event; a moment in time where landscapes exist between a transitory state of land and water. The onset is sudden and acute, arriving with speed and exigency. Remaining for just a brief moment in time, the unwelcome waters bring with it lasting devastation and ruin. Whether the elevated waters remain for mere minutes or hours, or in some cases for several days, the consequences of the aftermath last much longer. As time goes on and the memory of past flooding events fade, it is easy to forget the reality and severity that occurred throughout the original experience. The events from July 1, 1958 during the inundation of the nine "Lost Villages" demonstrate the ability of a flood to permanently alter the state of an inhabited landscape. The visibility of the flooded foundations just beneath the surface of the water have frozen the events of the flood in place, acting as permanent reminder to the destructive power of water. Much like these "frozen foundations", the proposed design for a network of Flood Towers aims to make visible the invisible; changing water levels and flow velocities

— factors that are often not easily noticed by the average person- are elements that greatly contribute to flooding and are often not noticed until it is too late. The Story of the "lost Villages" sheds light on why communities should not underestimate the consequences associated with residing in proximity to a floodplain. In order to learn from our past —and to avoid having a repeat of lost villages in the future - the reality of present day communities established along the St. Lawrence and Ottawa River will next be considered. 


\section{0| UNDERSTANDING THE WATERSCAPE}

"I'm not going to start blaming anyone else, the water was there and it had to go somewhere." —Hans Gruenwald Jr., mayor of Rigaud, Quebec ${ }^{18}$

${ }^{18}$ Les Perreaux, "What did we learn from 2017's floods in Quebec and Ontario? Inside the politics of water," The Globe and Mail, published January 5, 2018, https://www.theglobeandmail.com/news/national/quebec-ontario-floods-water-managementpolitics/article37511432/ 


\section{1| Converging Waterways}

The compounding events that led to the historical flooding throughout Quebec and Ontario in May of 2017 created flooding listed as the third most significant weather event of 2017 by the Canadian Meteorological and Oceanographic Society ${ }^{19}$. According to the Insurance Bureau of Canada, the spring flooding through Quebec and Ontario resulted in \$223 million in property damage, more than 5,0oo flooded properties, 550 roads completely washed away, and the loss of two lives. ${ }^{20}$ In order to understand the flooding event, we must first examine the configuration of the waterscape at the heart of the devastation. The crux of the flood damage occurred in eastern Ontario near Ottawa and southern Quebec near the Montreal Harbour.

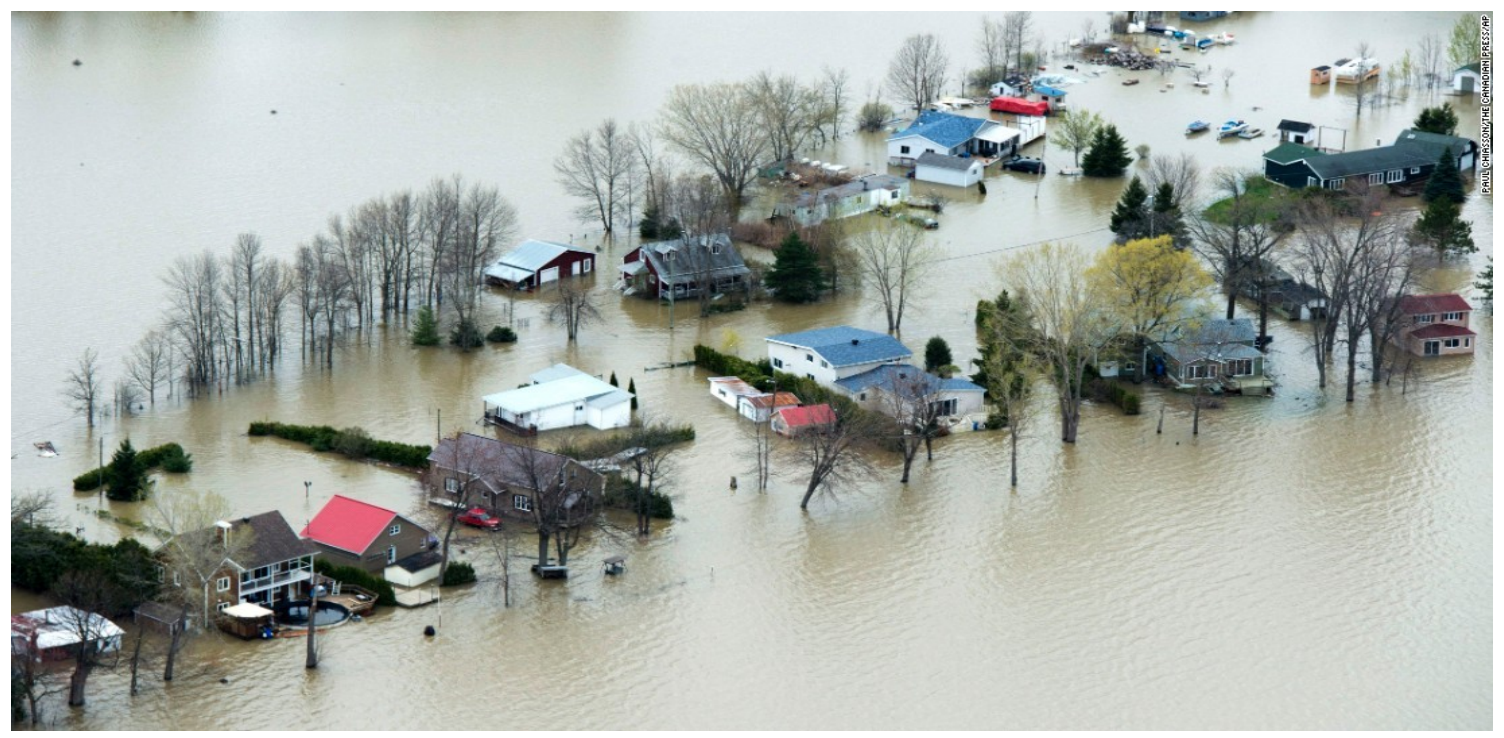

Figure 8 | The Ottawa River floods homes in Rigaud, Quebec, May 8, 2017 Source: CNN, accessed November 8, 2018, https://www.cnn.com/2017/05/08/world/gallery/canada-flooding0508/index.html

\footnotetext{
${ }^{19}$ David Phillips, "Canada's Top Ten Weather Stories 2017," Canadian Meteorological and Oceanographic Society, published January 7, 2018. https://bulletin.cmos.ca/canadas-top-ten-weather-stories-2017/

20 "Canada's Top Ten Weather Stories 2017," Canadian Meteorological and Oceanographic Society.
} 
These two regions meet at the convergence of the Ottawa River and the St.

Lawrence River before the combined waters empty into the Gulf of St. Lawrence and the Atlantic Ocean. The coalescence of these two mighty river flows desecrated the communities nearest their periphery. Dozens of communities declared states of emergency as more than 2,300 Canadian military personnel were mandated to assist with flood preparation and rescue relief efforts. Both the Ottawa River and the St. Lawrence River are complex waterways, each with their own unique hydrology, independent control boards, and particular ways in which they behave. The following section will consider each water system independently to understand its hydrological behaviours in relation to the events realized during the flooding of May 2017.

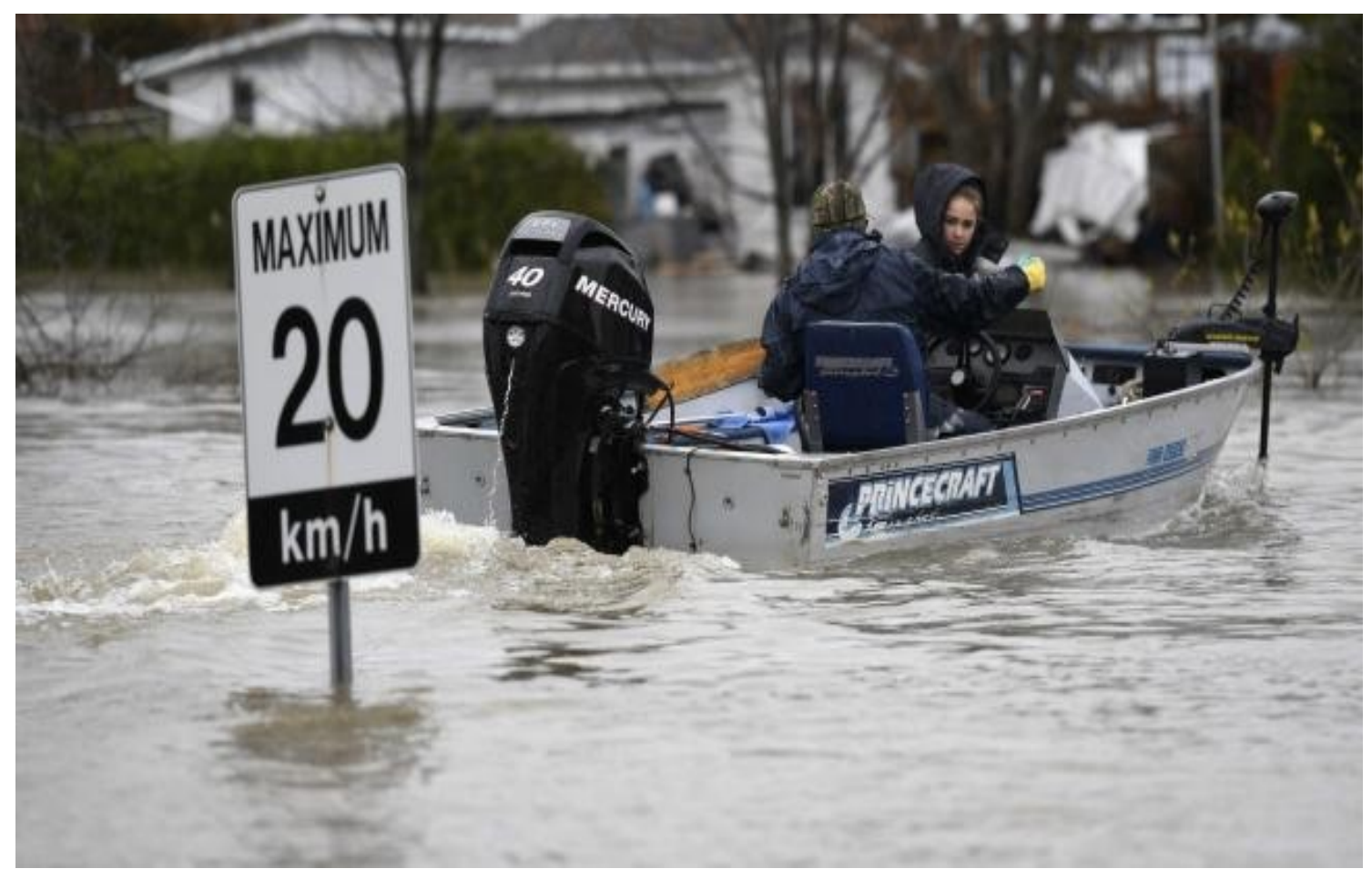

Figure 9 | The Ottawa River floods homes in Rigaud, Quebec, May 8, 2017 Source: CNN, accessed November 8, 2018, https://www.cnn.com/2017/05/08/world/gallery/canada-flooding0508/index.html 


\section{2| Lake Ontario \& The St. Lawrence River}

Lake Ontario and the St. Lawrence River form one of the world's most unique waterways. Sharing its edges with both the Canadian and American borders, [the St. Lawrence River] offers shared powerful economic forces and an impressive natural resource to both communities. ${ }^{21}$ Running for $1,197 \mathrm{~km}$, the river extends from Lake Ontario past Montreal and Quebec City, until it flows into the Gulf of the St. Lawrence. The river acted as the main navigational channel for explorers in Canada's early history, and remains to this day the focus of settlement for much of the province of Quebec. ${ }^{22}$ From Lake Ontario down past the Montreal Harbour there are numerous small communities established on the banks of the St. Lawrence, each at the mercy of the fluctuating river levels along the seaway. Inflows from Lake Ontario travel downstream to the St. Lawrence River through the Moses-Saunders power dam and Barnhart Island dam between Cornwall, Ontario and Massena, New York. "Water levels at Lake St. Louis [in the lower part of the St. Lawrence] are governed by the outflows from Lake Ontario and if not properly managed can have severe and catastrophic end results for the island of Montreal and riparian areas along the St Lawrence River."23 The dams in the lower portion of the river below Lake St. Francis operate as "run-of-the-river" facilities, referring to their lack of reservoirs and storage capacity. The enormous quantity of

\footnotetext{
${ }^{21}$ International Joint Commission, "Causes of 2017 Lake Ontario- St. Lawrence River Flood," Vimeo video, 4:26, June 18, 2018, https://vimeo.com/275669603.

22 "St. Lawrence River," The Canadian Encyclopedia.

${ }^{23}$ Jafaun Permansingh, "Hydrological Analysis of the Historical May 2017 Flooding Event in Montreal and Surrounding Areas," (BREE 631: IWRM Internship Project, McGill University, 2017).
} 
water being released from Lake Ontario into the St. Lawrence combines with the waters entering from the Ottawa River, magnifying any riparian damage that may occur.

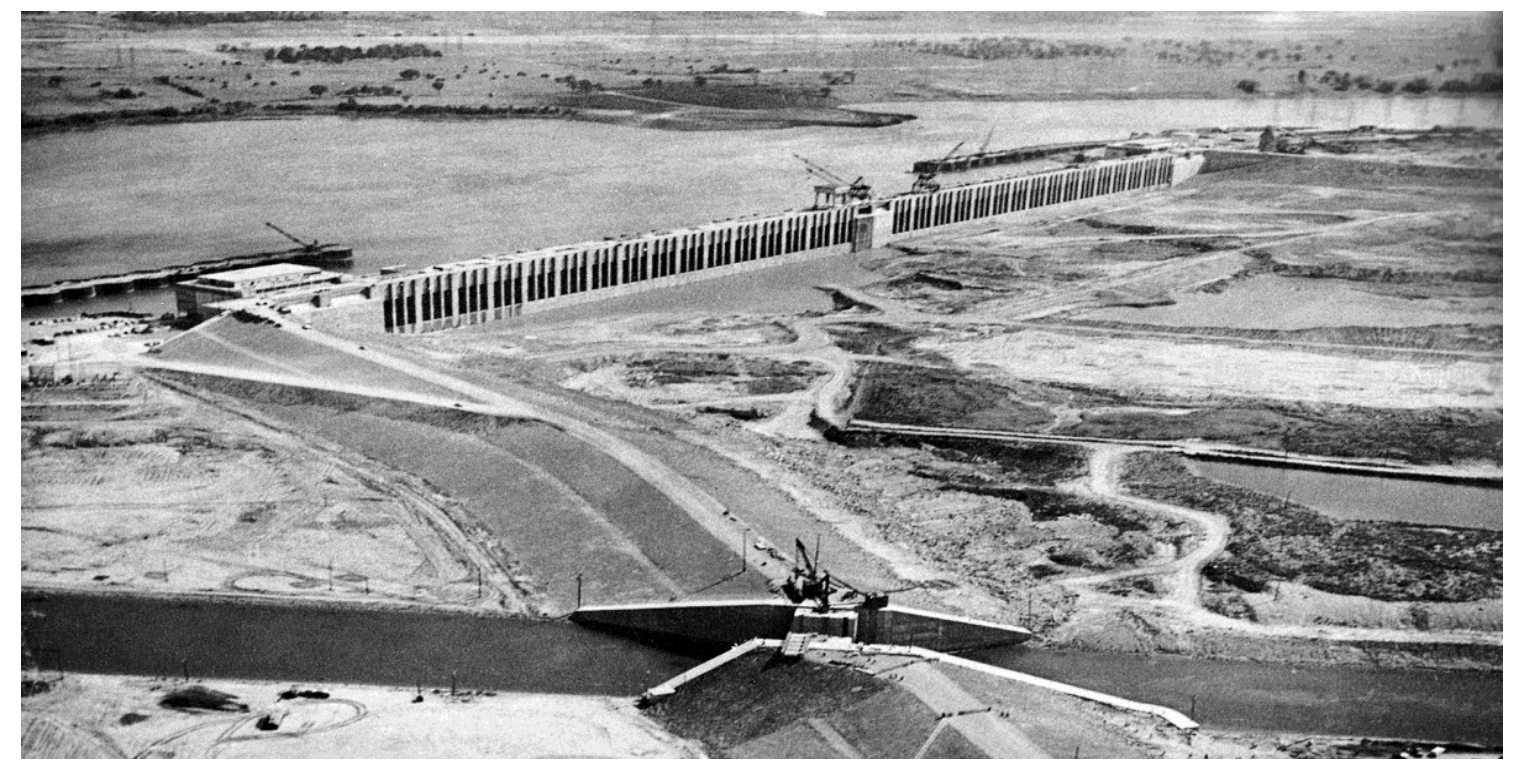

Figure 10 | Moses Saunders Power Dam, 1954 to 1958

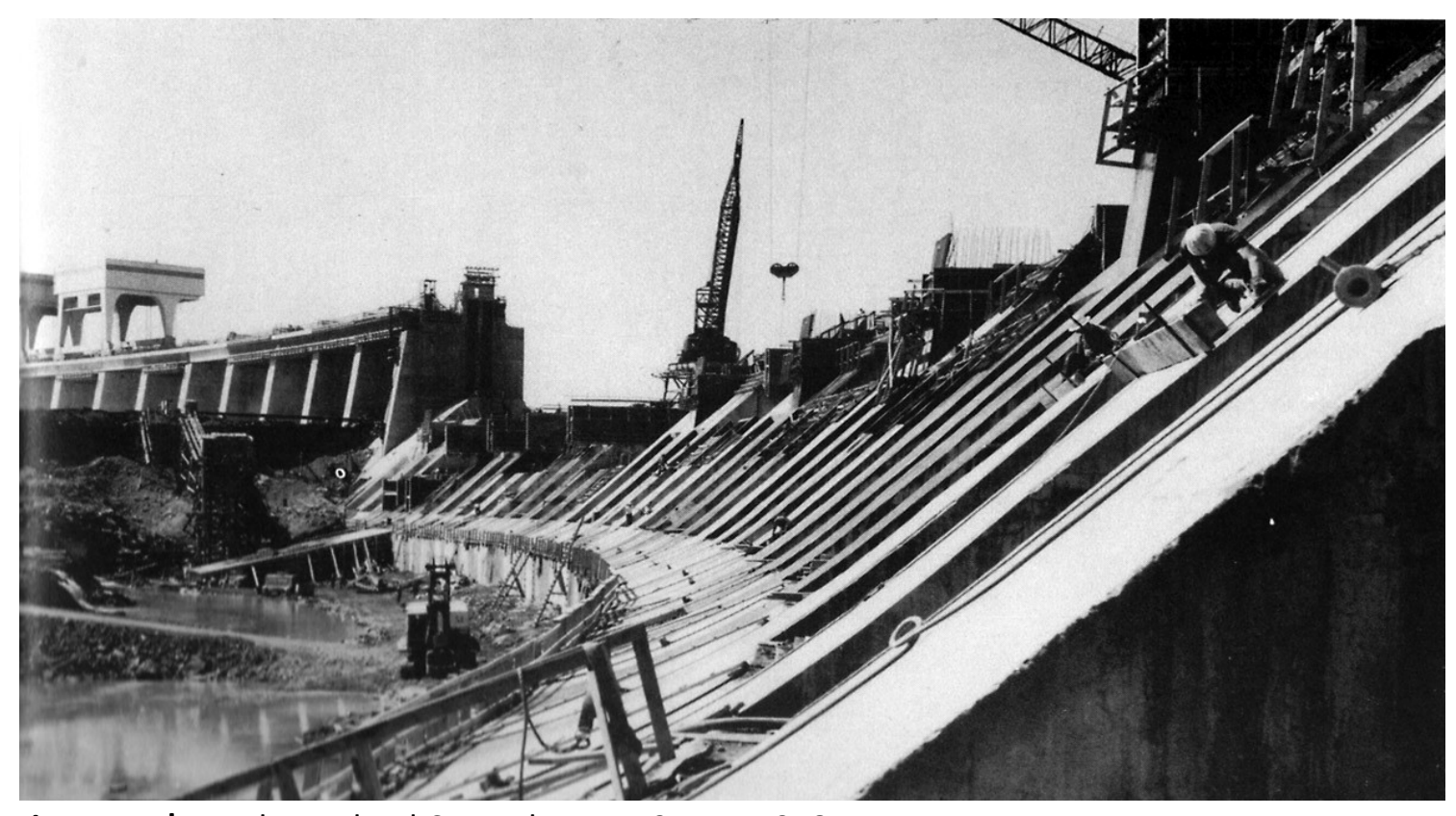

Figure 11 | Barnhart Island Control Dam, 1954 to 1958

Source: John Gleed, Figures from St. Lawrence Piks, accessed March 30,2019, http://stlawrencepiks.com/seawayhistory/seawayconstruction/cornwallmassena/index.html 


\section{3| The Mighty Ottawa River}

As the eighth largest river in Canada, the Ottawa River serves as the main tributary to the St. Lawrence Seaway. ${ }^{24}$ The river joins the mainstream of the St. Lawrence through channels leading to Lake St.-Louis and via a north-east route through Lake of Two Mountains. "The land between the various channels at the confluence of the [joined waterways] forms the archipelago on which the city of Montreal is built." ${ }^{25}$ The banks of the river sustain large urban developments including the densely populated Ottawa-Gatineau region. With over fifty major dams and hydro-electric generating stations, the Ottawa River is one of the most highly regulated rivers in Canada. ${ }^{26}$ In the upper extents of the river, there are thirteen principle reservoirs in the watershed each with the ability to store a large quantity of excess water. Dams in the lower section of the river however have little to no storage capacity and the waters are left primarily unregulated. Due to the limited storage capacity in the lower portion of the river, dams in this section must match their outflow with the volume of water coming from upstream. Once the dam reservoirs have reached their storage capacity, they must open their gates to allow the surplus runoff to continue downstream; dam operators throughout the basin downstream of the reservoir therefore have very little control in minimizing the impact of flooding to communities along its waterway.

\footnotetext{
${ }^{24}$ James H. Marsh \& Nathan Baker, "Ottawa River," The Canadian Encyclopedia, last edited November 30, 2018, https://www.thecanadianencyclopedia.ca/en/article/ottawa-river

25 "Ottawa River," The Canadian Encyclopedia.

26 "Flooding FAQ," Ottawa River Regulation Planning Board, http://www.ottawariver.ca/flooding-faq.php
} 


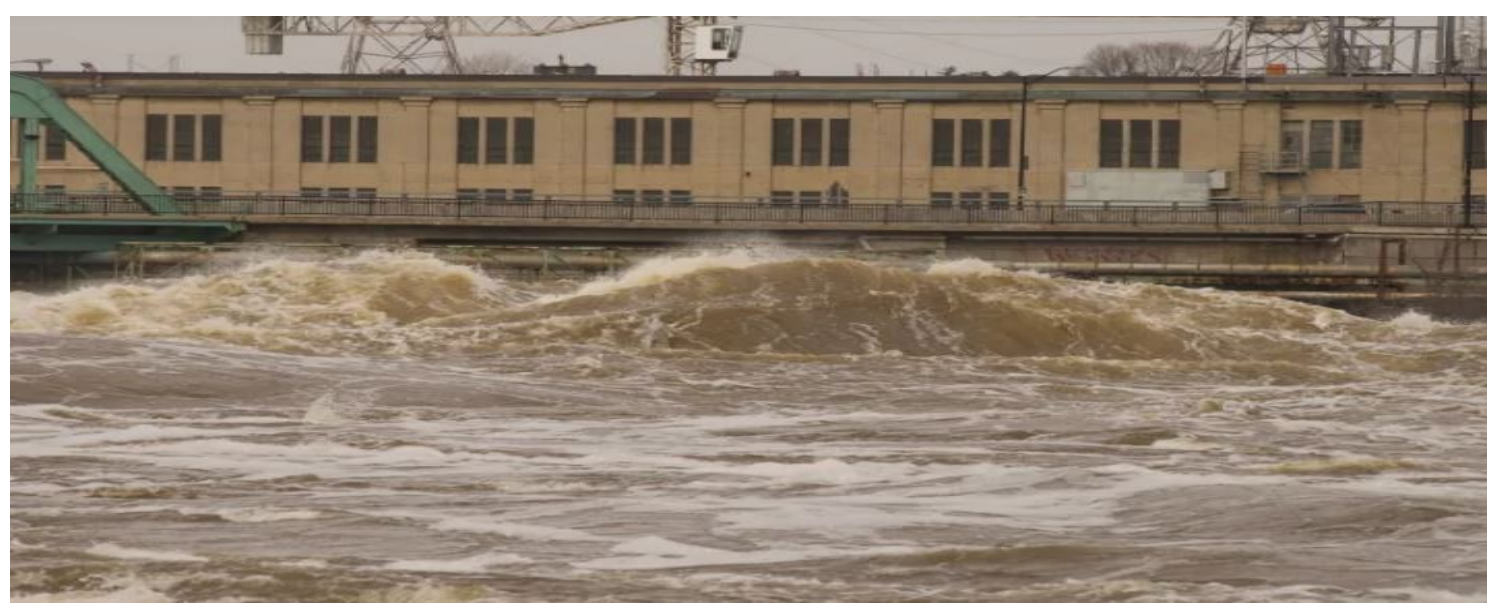

Figure 12 | The Carillon Generating Station is located about 19 kilometres from Rigaud, one of the Quebec communities hardest hit by recent flooding, May 2017

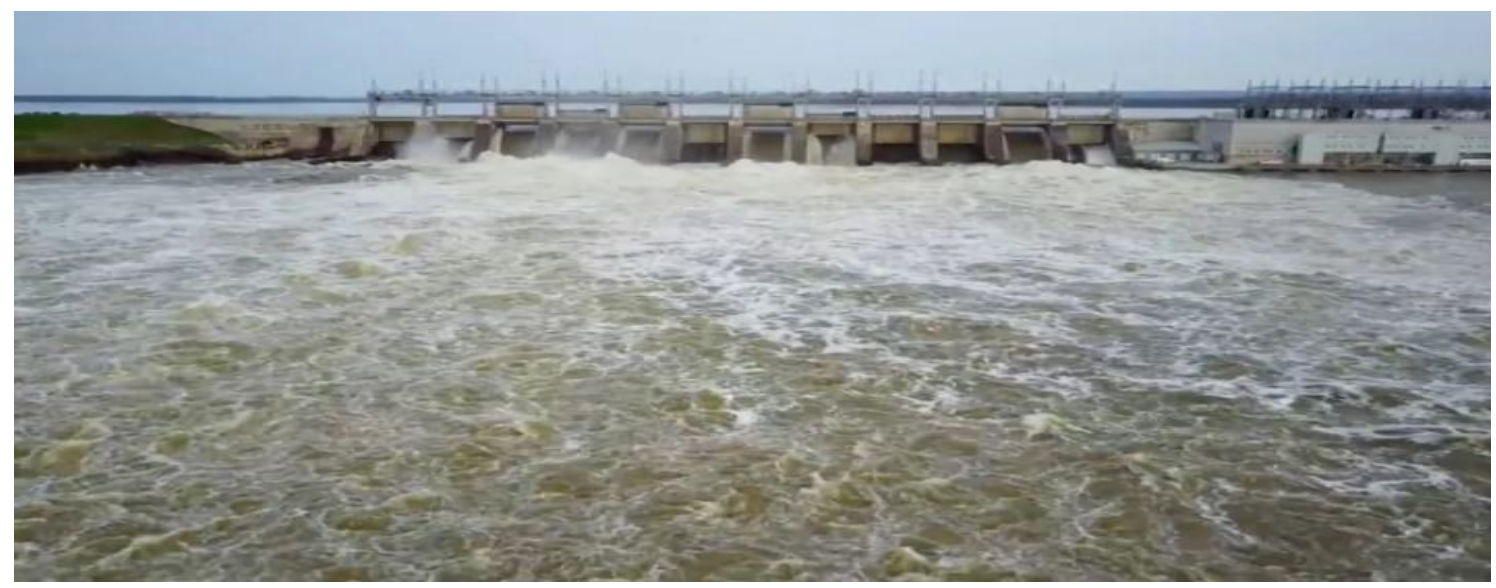

Figure 13 | A wave crests near the Chaudière Bridge on the Ottawa River on May 8, 2017 Source: CBC, accessed March 30, 2019, https://www.cbc.ca/news/canada/montreal/ottawa-river-hydro-dams-doing-their-job-saysquebec-environment-minister-1.4105058

Littoral communities southeast of Ottawa towards Montreal are therefore often subject to severe flooding. Inhabitants along the St. Lawrence and Ottawa rivers are offered a false sense of security as they rely profoundly on the river's infrastructure of dams and spillways to provide protection; to their dismay, these massive infrastructures and their operators have marginal control in mitigating flooding. 


\section{0| THE FLOOD}

"At first I felt like I should fight, but now I've made my peace with it, Ms. Hardy said. Holding on doesn't do anything. For us it's over." -Celine Hardy, Pierrefonds resident 


\section{1|The Flood of May 2017}

Historically high outflows from Lake Ontario beginning in late May of 2017 caused relentless flooding in eastern Ontario and southern Quebec. Countless communities on both sides of the waterway experienced record flooding, millions of dollars in property damage and an endless sense of loss and emotional fatigue. A variety of factors can be attributed to the record high water levels experienced across the Lake Ontario and St. Lawrence River basin, but quite simply, the high water levels were primarily influenced by record precipitation received across the basin in a short period of time. ${ }^{27}$

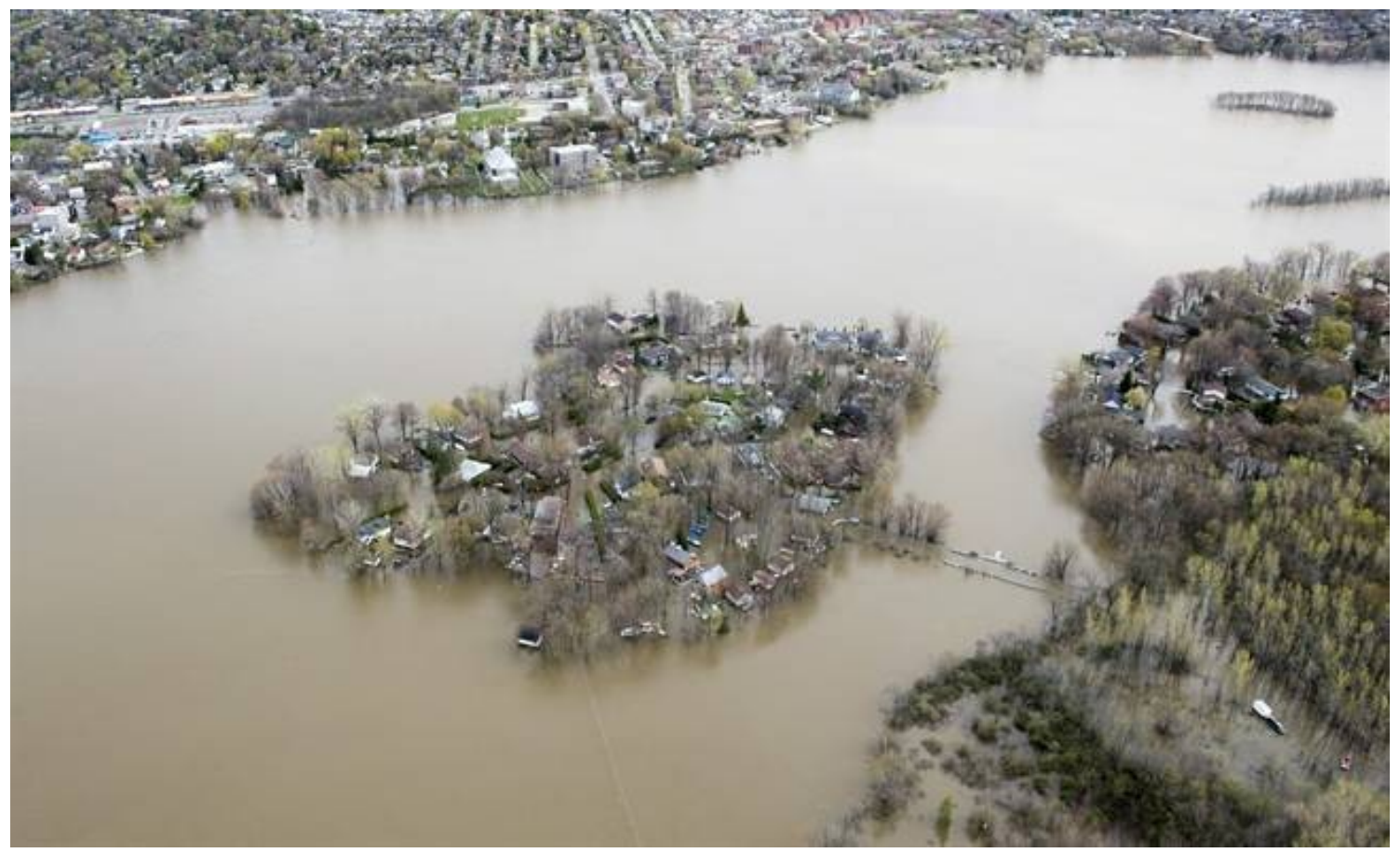

Figure 14 | lle Mercier covered in floodwater is seen on the Riviere des Prairies on the north part of Montreal, May 8, 2017

Source: Paul Chiasson, accessed November 8, 2018, https://globalnews.ca/news/3438421/quebec-floods-montreal-area-school-closures-forwednesday-may-10/

\footnotetext{
27 "International St. Lawrence River Board: Observed Conditions and Regulated Outflows 2017," International Joint Commission, published May 25, 2018,

https://www.ijc.org/sites/default/files/2018-08/ILOSLRB_FloodReport2017.pdf.
} 


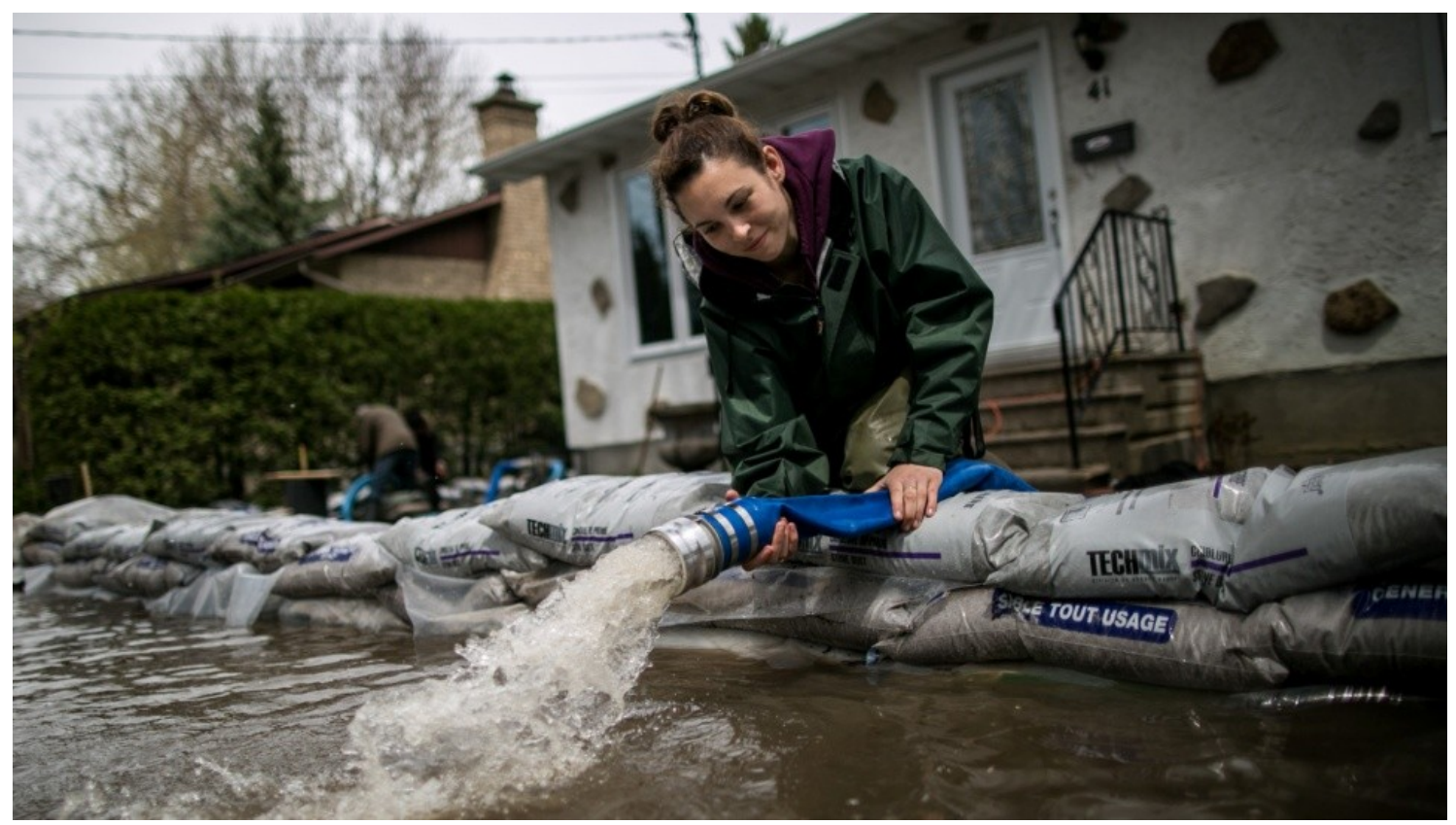

Figure 15 | A resident of Mercier Island drains her house of floodwaters, May 9, 2017 Source: CNN, accessed November 8, 2019, https://www.cnn.com/2017/05/08/world/gallery/canada-flooding-0508/index.html

In the early months from January through March, increased inflows from Lake Erie, combined with heavy rainfall and snowmelt in the Lake Ontario basin caused the lake to rise two feet, accruing to twice the normal amount ever recorded for this time of year. ${ }^{28}$ Unusual freeze-thawing conditions of the ice throughout the winter added to the extended accumulation of inflows. Two feet of water may at first seem insignificant, but to put into perspective the magnitude of this increase, two feet of water over the surface area of Lake Ontario is equal to roughly 12 cubic kilometers of water —all of which is funneled through a river channel that is on average $2 \mathrm{~km}$ wide; this is a staggering amount of water. This sudden incursion of severe flows from Lake Ontario through the river flooded waterfront communities on both sides of the seaway.

\footnotetext{
${ }^{28}$ International Joint Commission, "Causes of 2017 Lake Ontario- St. Lawrence River Flood."
} 


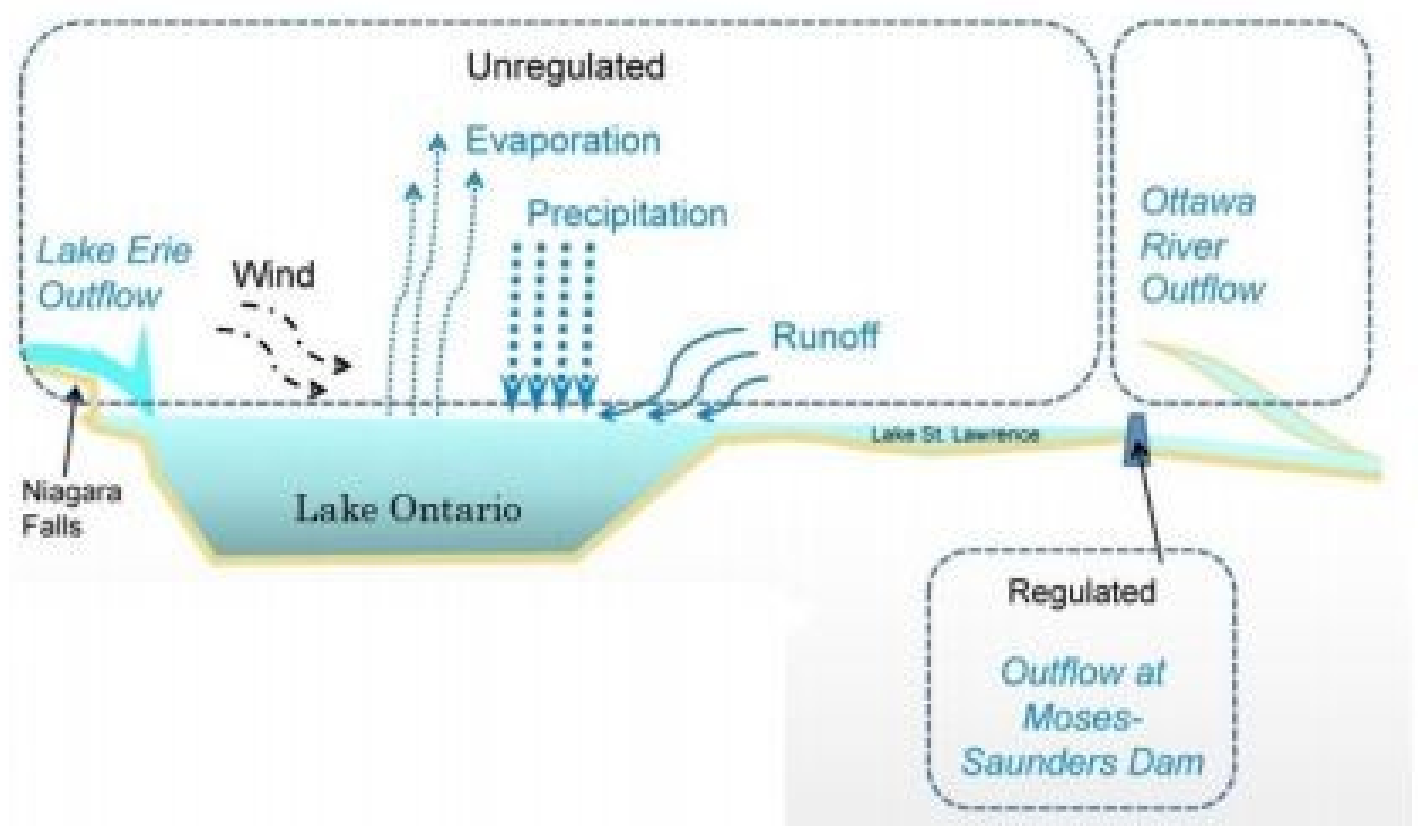

Figure 16 | Sketch Illustrating the Hydrology of Lake Ontario, 2017

Source: IJC, accessed March 30, 2019, https://www.mcgill.ca/h2oinnovation/files/h2oinnovation/2017floods_analysis.pdf

Habitants of the impacted communities blamed dam operators for the inundation of their shoreline properties, questioning why they did not better manage outflows to mitigate flooding. What most do not understand is that under these extreme conditions there were no other actions that could have been taken to reduce flooding in one part of the waterway without making it worse in another part. ${ }^{29}$

\footnotetext{
${ }^{29}$ International Joint Commission, "Causes of 2017 Lake Ontario- St. Lawrence River Flood," Vimeo video, 4:26, June 18, 2018, https://vimeo.com/275669603.
} 


\section{2| Landmark as Tracker}

Let's consider for a moment white water kayakers who —in order to be safe and to perform proficiently in their sport—have developed a profound understanding of the hydrology of the rivers they frequent. ${ }^{30}$ These athletes use river gauges to track what level the river is running at and use this marker to understand how the features are behaving at that given level; they simultaneously refer to the river's discharge to gain a full scope of the water conditions. ${ }^{31}$ Much like kayakers who have developed a river awareness, riverside residents whose properties are susceptible to flooding are typically able to discern when water levels in and around their own property are increasing. They use familiar landmarks—such as trees, fence posts, dock supports, or homemade gauges—as points of reference to track the rising waters. At such a small, localized scale, these water level changes are easy to recognize. Unfortunately, by the time these changes in water levels are noticed in these residential areas, it is often too late to adequately prepare for or retreat from the floodwaters. Flooding begins at the macro scale of the river and slowly works its way down to the micro scale of the residence. If we were able to understand how the river was behaving — like whitewater kayakers understand river velocity, discharge and water level—prior to a flood reaching our neighbourhoods, perhaps property damages could be abated.

\footnotetext{
${ }^{30}$ River hydrology is the study of rivers and waterways and considers how they behave; terms to consider as part of hydrology are water level, flow velocity and volume discharge.

${ }^{31}$ River discharge is the volume of water flowing through a river channel at any given point; discharge is measured in cubic meters per second (cms); dependent on precipitation, evapotranspiration and storage factors.
} 


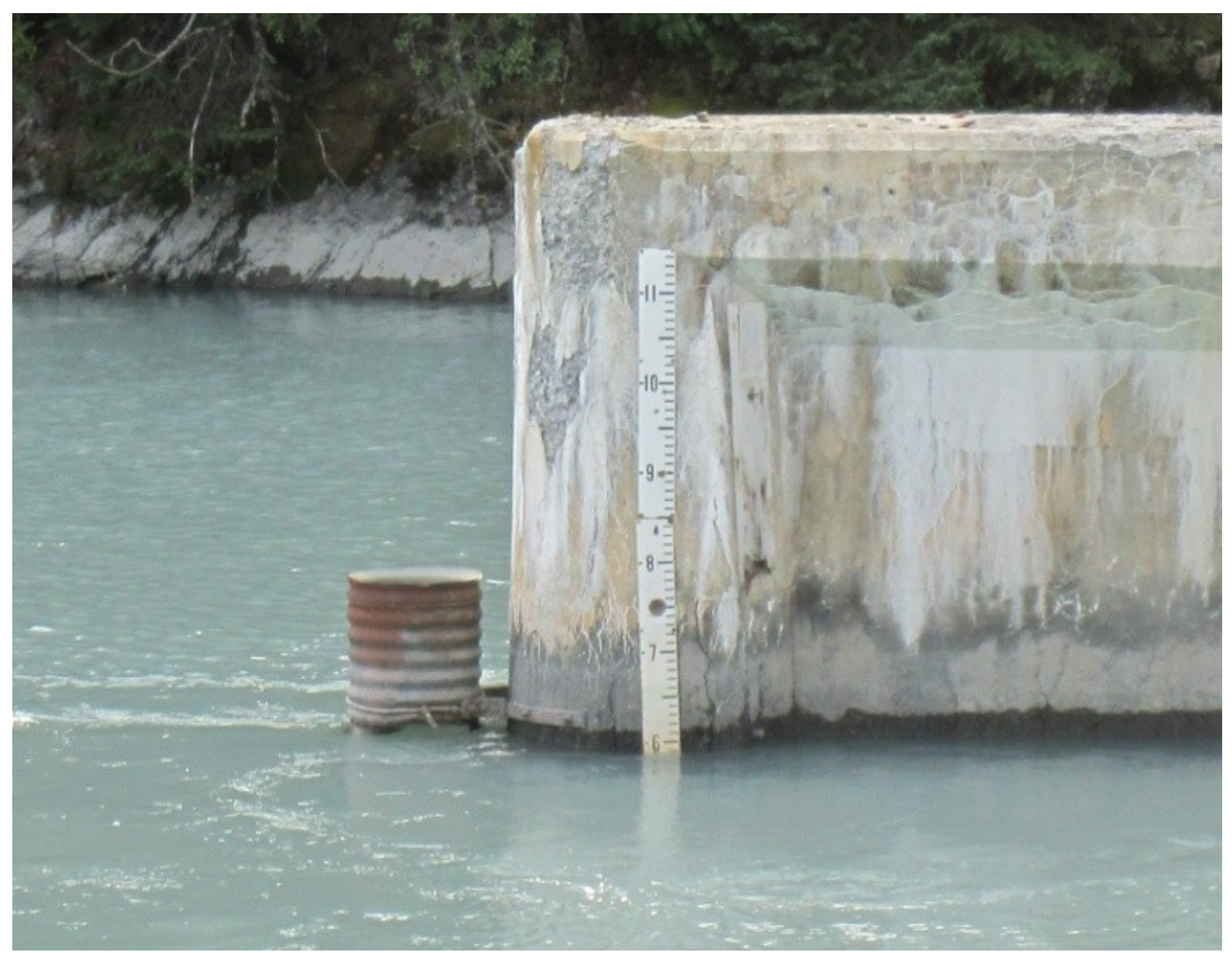

Figure 17 | Trail River staff gauge on old river pier

Source: National Weather Service Advanced Hydrological Prediction Service, accessed March 30, 2019,

https://water.weather.gov/ahps2/hydrograph.php?wfo=pafc\&gage=mpta2

The concept of "landmark as tracker" can be used at a larger, more communal scale to make communities visually aware of their local river's hydrology. Unbeknownst to most, flooding along rivers has less to do with water level and more to do with volume discharge. Discharge - unlike water level that can be visually understood - is more difficult to comprehend as it is typically perceived as a numerical value. This thesis' proposed network of Flood Towers will do exactly that; it will make visible the invisibility of a river's hydrology. 


\section{3| Hydrometric Data Stations}

Early warning and awareness for a flooding event is vital for communities to limit or mitigate property damage. Environment Canada works in partnership with provinces and territories to "provide crucial information to help forewarn Canadians of potential flooding dangers." ${ }^{22}$ Environment Canada's Water Survey of Canada (WSC) is the "national authority responsible for the collection, interpretation and dissemination of standardized water resource data and information in Canada. "33 They oversee a network of over 2,500 active hydrometric data stations across Canada, while maintaining a historic database for over 5,500 non-active sites in the country. ${ }^{34}$ Much like residents who use landmarks on their property to track river changes, the government oversees a network of gauges that serve a similar purpose. Dispersed along rivers, lakes, reservoirs and tributaries, hydrometric data stations collect and record water statistics, including water level and river discharges. The data collected by WSC's hydrometric stations are used "by provincial and territorial governments to issue flood bulletins, advisories and warnings via flood forecasting centers." 35

\footnotetext{
32 "Water survey of Canada and provincial/territorial flood information," Government of Canada, last modified January 11, 2017. https://www.canada.ca/en/environment-climate-change/services/wateroverview/quantity/monitoring/survey/provincial-territorial-flood-information.html

33 "Water Survey of Canada," Government of Canada.

34 "About the Water Survey of Canada," Government of Canada, last modified May 28, 2018. https://www.canada.ca/en/environment-climate-change/services/wateroverview/quantity/monitoring/survey/about.html

35 "Water Survey of Canada," Government of Canada.
} 


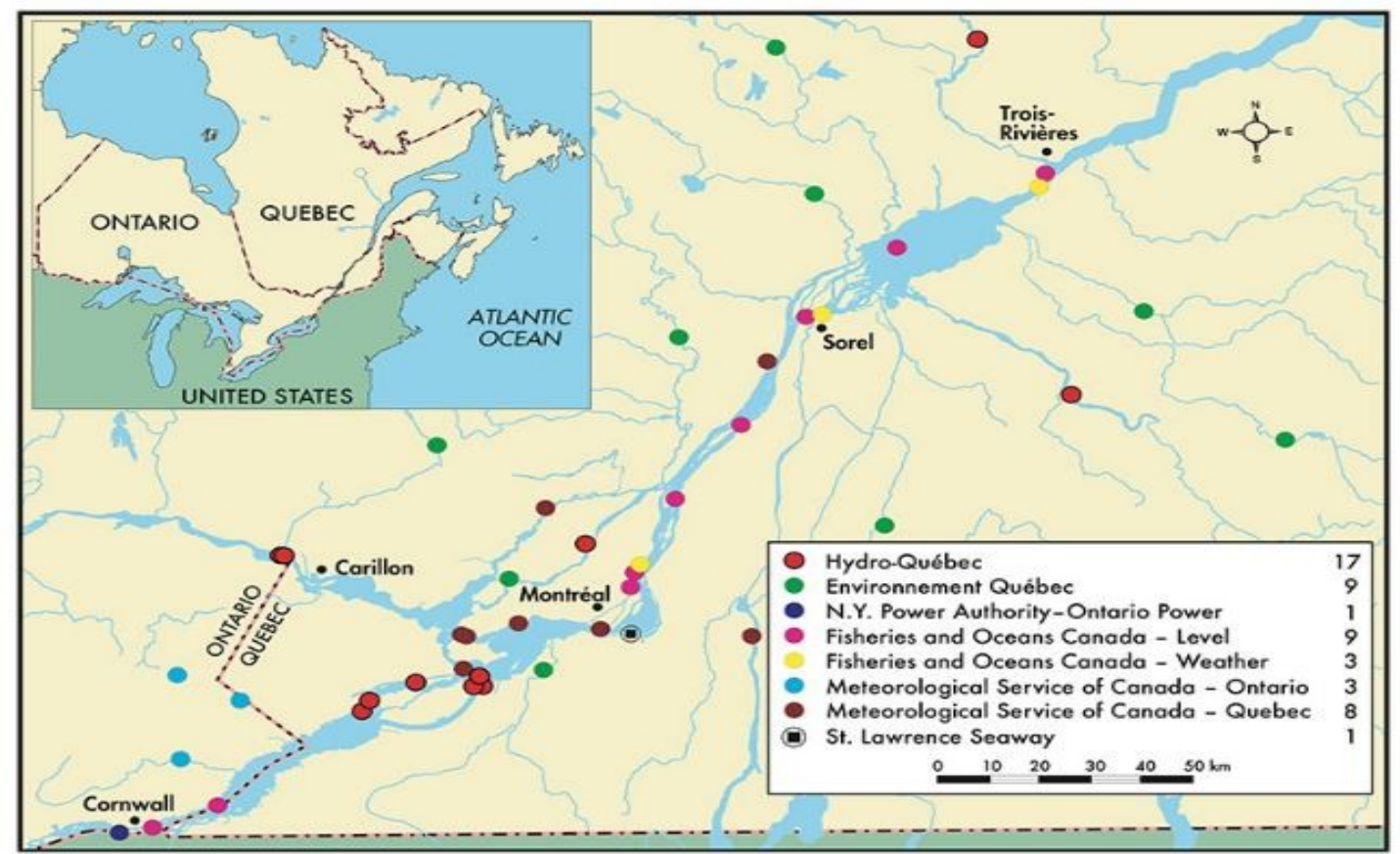

Figure 18 | Locations of the main hydrometric stations along the fluvial portion of the system and its main tributaries

Source: Accessed March 9, 2019, http://planstlaurent.qc.ca/en/state_monitoring

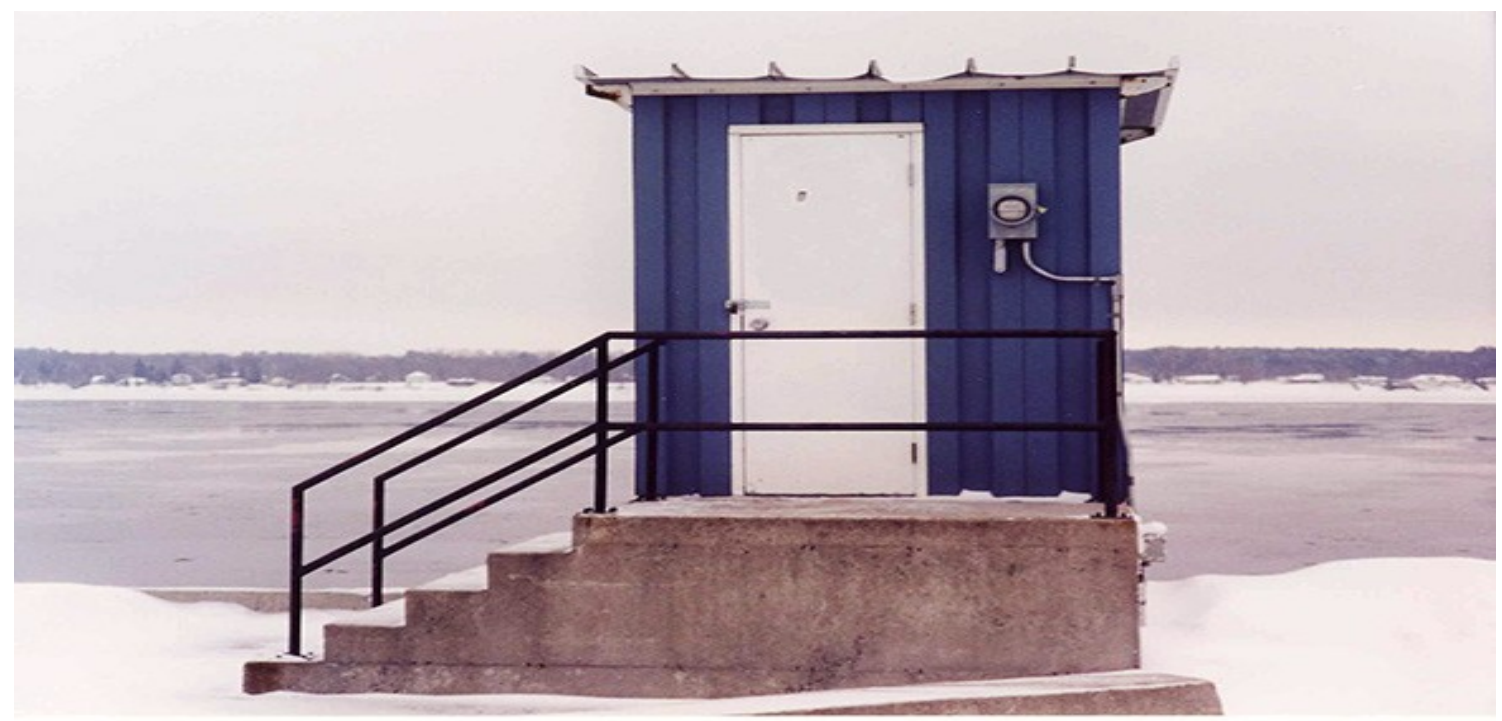

Figure 19 | Hydrometric Station at Lanoraie

Source: Environment Canada, accessed March 9, 2019, http://planstlaurent.qc.ca/en/state_monitoring 
For property owners residing in proximity to a floodplain, it is crucial that they receive flood warning data as soon as possible. The real-time information collected at the hydrometric data stations are transmitted to the Water Survey Canada headquarters in Burlington, Ontario via satellite or land-line transmissions. Although termed "real-time", it can take upwards of six hours from the time of observation for the data to be posted to the public. ${ }^{36}$ As the Water Office with the Government of Canada outline on their website, "it takes up to six hours to reach the web page because data from all of our over 1900 real-time gauging stations must be transmitted from the field, processed in our hydrometric data computation system, and then transferred to our web site on a continuous basis (that's about 25000 independent data points per hour!)." ${ }^{37}$ This six hour delay can be detrimental for community flood preparation and mitigation. There is an evident need to improve our current flood forecast system as to not subject communities to delays of the electronic system.

\footnotetext{
36 "Disclaimer for Hydrometric Information," Government of Canada, last modified December 10, 2018. https://wateroffice.ec.gc.ca/disclaimer_info_e.html

37 "Frequently Asked Questions," Government of Canada, last modified December 10, 2018. https://wateroffice.ec.gc.ca/contactus/faq_e.html
} 


\section{4| The Need for A New System}

"While extremes have happened in the past, there is no doubt that 2017 was a rare event within the historical record, ${ }^{138}$ surpassing limits predicted by the 10oyear flood. ${ }^{39}$ The uncertainty associated with climate change challenges the assumption that the "10o-year" probabilities can continue to be used as reliable estimates. Communities should be solicitous when relying too heavily on the accuracy of the 10o-year flood to determine the likelihood of future flooding events. Depending on the amount of data available in their area, the accuracy of said data, land-use changes in the river, climate cycles, and how well the data fits the statistical probability distribution, ${ }^{40}$ the datum could be completely unreliable. Rather than continuing to rely on out-dated statistics such as the "10o-year flood", the rare conditions of 2017 highlight the importance of reevaluating the current forecasting system available for predicting future flood events. We must urgently consider the provision of an improved flood warning system so that community members may have the chance to better prepare for a flood. The architecture of the Flood Tower network will primarily serve as a large scale river gauge that provides communities with an immediate flood warning system.

\footnotetext{
38 "Great Lakes - St. Lawrence River Adaptive Management (GLAM) Committee: Summary of 2017 Great Lakes Basin Conditions and Water Level Impacts to Support Ongoing Regulation Plan Evaluation," International Joint Committee, published November 13, 2018, https://ijc.org/sites/default/files/201811/GLAM_2017_MainReport_FINAL-20181129_2.pdf

${ }^{39}$ The "100 year flood" has a 1 in 100 chance of being equaled or exceeded in any 1 year, and has an average recurrence interval of 100 years. ${ }^{40}$

${ }^{40}$ Holmes, "The 100-Year Flood," USGS.

${ }^{40}$ Holmes, "The 100-Year Flood," USGS.
} 


\section{0| INTERNATIONAL PRECEDENTS}

"Water is not an enemy. It was never an enemy. It's not a fight, because you will always lose." ${ }^{\text {41 }}$ -Henk Ovink, Special Envoy for International Water Affairs for the Netherlands

41 "What the Dutch Can Teach the World About Managing Floods," CBC Radio, published September 3, 2017. https://www.cbc.ca/radio/thesundayedition/the-sunday-editionseptember-3-2017-1.4265299/what-the-dutch-can-teach-the-world-about-managing-floods1.4270589 
The following section of this thesis will investigate three case studies of international precedents of how others are dealing with flooding in their communities. The first two precedents have adopted the approach of inviting the floodwaters into their communities rather than restricting the rising water levels with hardscaped infrastructure. Conversely, the third case study considers the proposal for a parapetic landscape whose architecture retreats from the threat of coastal erosion. Rather than continuing to reinforce the defenses that fail us, there is a critical urgency for communities to investigate the form and applicability of their current flood defenses. "There has been a shift in focus in Europe and North America away from 'hard' engineering solutions, such as channel alteration and river embankment construction, towards encouraging more natural flood management solutions within catchments. ${ }^{42}$ Both the United Kingdom and the Netherlands are pertinent examples of nations that promote spatial rather than purely technical solutions to flood management, by encouraging more room for peak river discharges into their communities. ${ }^{43}$ Two precedent studies will next be examined, the United Kingdom's Making Space for Water program and the Netherland's Room for Rivers program, which test the potential of deliberately allowing floodwater to enter into their communities rather than restricting its flow with hardscaped infrastructure.

\footnotetext{
${ }^{42}$ Williams, Lauren, Harrison, Simon, and O'Hagan, Anne Marie, "The Use of Wetlands for Flood Attenuation," Report for An Taisce by Aquatic Services Unit, University College Cork, 2012, 6.

${ }^{43}$ Williams, "The Use of Wetlands for Flood Attenuation," 6.
} 


\section{1 | CASE STUDY NO. 1: COASTAL REALIGNMENT AT MEDMERRY}

LOCATION: Medmerry, West Sussex, United Kingdom

WHO: United Kingdom's Environment Agency

YEAR: 2014

In 2011, the United Kingdom government's Environment Agency published TE210o, a report outlining their plan to manage tidal flood risk in the Thames estuary until the year $2100 .{ }^{44}$ The TE210o is the first major flood risk project in the United Kingdom to have put climate change adaptation at its core. One particular approach outlined in the document considers using coastal marshland as sacrificial territory that would be allocated to absorb the threat of unexpected floodwater. This approach, known as coastal realignment, involves the act of deliberately making a breach in coastal defense systems — such as puncturing voids in a sea wall - to allow surfeit water to push through the defense and pool into a designated landscape; this is intended to absorb the impact of the excess waters, protecting land further downstream from flooding. This innovative initiative provides a useful model for flood attenuation by utilizing new incentives tailored to the delivery of flood management objectives through land use change. ${ }^{45}$ The project tests the applicability of a hybridized landscape system that works with nature, rather than attempting to fight the inevitability of flooding with hardscaped infrastructure.

\footnotetext{
${ }^{44}$ Environment Agency, "TE2100 Plan Managing Flood Risk Through London and the Thames Estuary," published November 2012, https://www.gov.uk/government/publications/thames-estuary-2100-te2100

${ }^{45}$ Williams, "The Use of Wetlands for Flood Attenuation," 10.
} 


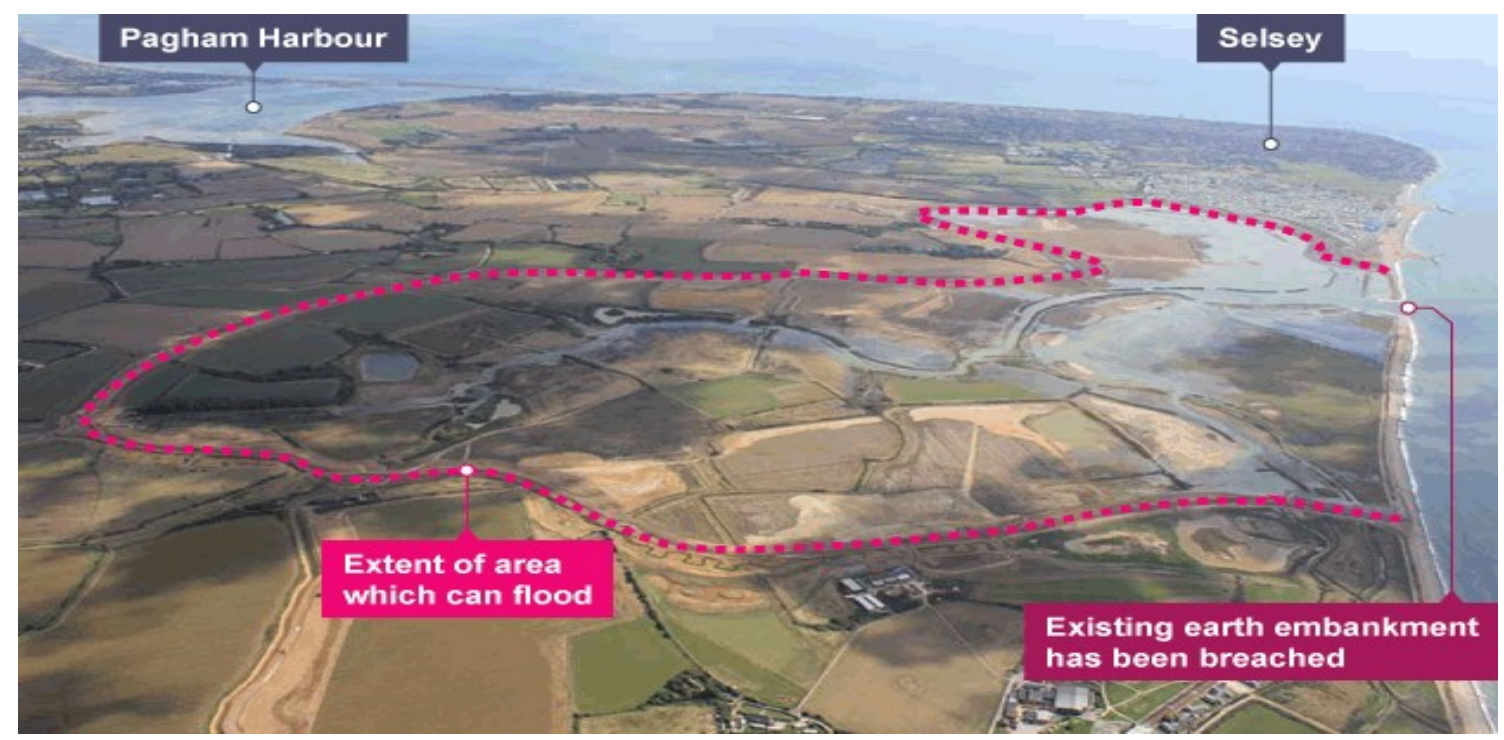

Figure 20 | Coastal Realignment at Medmerry, 2014

Source: Accessed November 18, 2018, https://oppla.eu/casestudy/18379

The project consisted of building a new seven kilometer long shingle stone sea wall two kilometers further inland from their existing wall. The wall was then punctured allowing excess tide water to flow into the neighboring salt marshes behind the flood defense. Theoretically, the realignment scheme has yielded an environment able to withstand a 1 in 1000 year flood and has created a new salt water marsh ecosystem. Although the project was successful in lengthening the timeline in which communities will be safe from the encroachment of water, established communities near the pushed-back periphery remain under sea level and are still within the floodplain. Pushing back the flood defense wall towards established communities simply delays their chances of flooding, but does little to eliminate the final effects of a flood event. Without raising the communities above the expected rising flood zone, or removing them altogether, these communities are still at risk of being inundated by rising sea levels in the future. 


\section{2 |CASE STUDY NO. 2: ROOM FOR THE WAAL RIVER}

LOCATION: Waal River, Nigmegen, Netherlands

WHO: The Dutch Ministry of Infrastructure and Environment

YEAR: 2018

Flooding is of high priority for the Dutch Ministry of Infrastructure and the Environment as more than half of the communities in the Netherlands lie below sea level. In 2006, the Dutch government implemented an anti-flooding scheme known as Room for the River intended to address the problem of flooding in their communities. The action plan is innovative in its approach; rather than fight the rising water levels by building higher flood defenses around their communities, planners are inviting the floodwaters in. Room for the River encompasses a master plan scheme involving thirty individual site locations across the Netherlands where existing landscapes will be altered to make more room for floodwaters.

One Dutch project in particular, the Room for the Waal River surrendered previously developed land in order to widen the extents of the river. The Waal connects the port of Rotterdam to the rest of Germany and serves as the main tributary branch to the Rhine river. Close to the German border, the city of Nijmegen finds itself on the edge of a narrow section of the Waal that tapers to a sharp bend. This bottlenecked section of river is prone to severe flooding and has relied on a system of dikes as its main defense system in the past. High water levels in 1993 and 1995 prompted the evacuation of 250,00o Nijmegen residents and convinced Dutch authorities that new measures of community protection would 
be required moving forward..$^{46}$ The project involved relocating dikes $350 \mathrm{~m}$ further inland and dredging a $3.5 \mathrm{~km}$ long flood relief channel to act as a bypass for floodwaters . The idea is that during periods of high water part of the Waal will be diverted through the new channel and will reduce the chance of flooding.

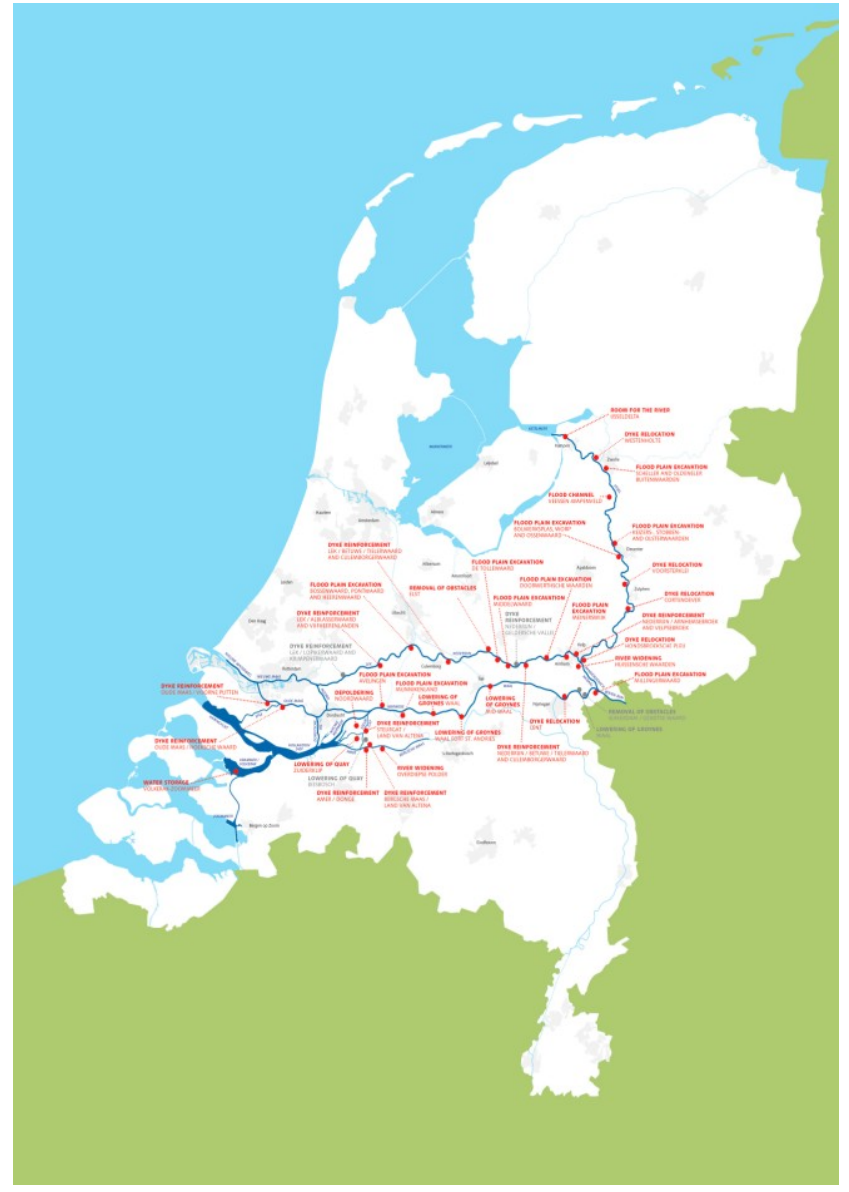

Figure 21 | Room for the River Master Plan, 2018 Source: Accessed November 18, 2018, https://www.ruimtevoorderivier.nl

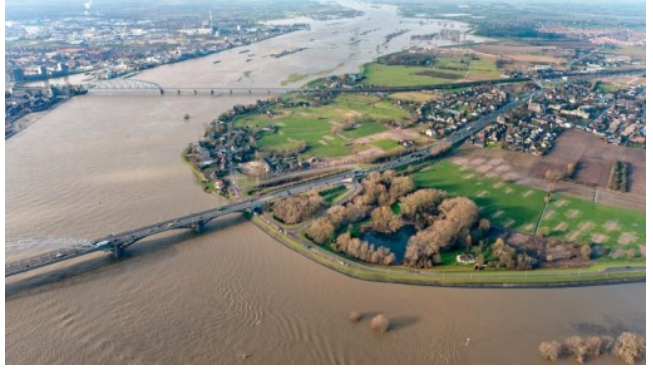

Figure 22 | Room for the River Nijmegen Before, 2018 Source: $\mathrm{H}+\mathrm{N}+\mathrm{S}$ Landscape Architects, accessed November 18, 2018, http://www.landezine.com/index.php/2016/08/room -for-the-river-nijmegen-by-hns-landscape-architects/

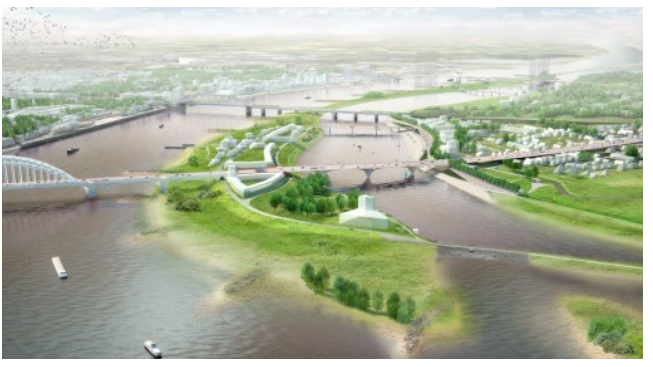

Figure 23 | Room for the River Nijmegen After, 2018

Source: $\mathrm{H}+\mathrm{N}+\mathrm{S}$ Landscape Architects, accessed November 18, 2018,

http://www.landezine.com/index.php/2016/08/room -for-the-river-nijmegen-by-hns-landscape-architects/

\footnotetext{
46 "How the Dutch Make 'Room for the River' by Redesigning Cities" Higher and higher dykes will not keep the waters at bay under climate change," Scientific American, published on January 20, 2012, https://www.scientificamerican.com/article/how-the-dutch-make-room-for-the-river/
} 
The bypass channel resulted in the creation of an elongated island, much like an urban river park, suitable for new recreational activity and ecological development. Roughly fifty properties had to be demolished as a result of the development, requiring negotiations and compensation for the property owners under the Netherlands' eminent domain laws. ${ }^{47}$

The outcome of the redevelopment scheme along the Waal river shares similar characteristics to the relocation of the "Lost Villages" along the St. Lawrence Seaway in 1958. Involving the local people - especially those whose properties were sacrificed to the flood defense efforts - was important for the longevity and prosperity of the redevelopment scheme. Ultimately these communities had little input in their uprooting, forever serving the purpose of sacrificial land for the benefit of future flood alleviation. Although strategies such as coastal realignment can be useful in reducing the impact of rising water levels on communities, such strategies will be insufficient on their own to completely eliminate flooding. Rather than inviting the waters in, we could consider the alternative of withdrawing our communities all together from the unstable landscapes.

47 "How the Dutch Make 'Room for the River' by Redesigning Cities," Scientific American. 


\section{3|CASE STUDY NO. 3: THE RETREATING VILLAGE}

LOCATION: North, Northfolk, United Kingdom

WHO: Laura Allen and Mark Smout, Smout Allen

YEAR: 2005

Two professors at the Bartlett School of Architecture in London, United Kingdom - Mark Smout, Professor of Architecture and Landscape Futures, and Laura Allen, Professor of Architecture and Augmented Landscapes - are partners at the Smout Allen architecture firm. The duo typically pursue architectural competitions and/or conceptual design projects that allow the freedom to explore the dynamic relationship between the natural and the man made. ${ }^{48}$ Smout Allen's The Retreating Village is a conceptual design project that looks at the threat of coastal erosion for the village of Happisburgh in Northfolk that is falling into the adjacent sea. The project questions whether territories vulnerable to coastal erosion can remain occupied in the event of erosion; the aim of the project is to propose an architectural language of representation that inhabits the disintegrating territory. ${ }^{49}$ Climate change and rising sea levels are proving to be detrimental to the dunal landscape of Norfolk and sea defense structures attempting to protect the low-lying village are failing. Smout and Allen have proposed a "different model for coastal inhabitation that can survive and prosper

\footnotetext{
48 "About," Smout Allen, http://www.smoutallen.com/about

${ }^{49}$ Laura Allen and Mark Smout, "Research Output 2: The Retreating Village," published 2005. http://discovery.ucl.ac.uk/9740/1/9740.pdf
} 
in this disintegrating territory between sea and stable land." ${ }^{50}$ Their proposal, an architecture that responds to the changing conditions of an unstable landscape, includes the design for a village of houses and infrastructure fabricated to physically retreat from the threats of the eroding shoreline.

When read from the air the landscape provides evidence of the deserted villages. Former buildings and paths leave banks and hollows in the ground as markings of their layout and land use. (Laura Allen, 2005).

Through a series of hybrid digital/hand drawings and architectural models, the project uses multiple viewpoints to emphasize the dissolution of the coastal landscape. The architecture collects and relocates as the landscape collapses around it.

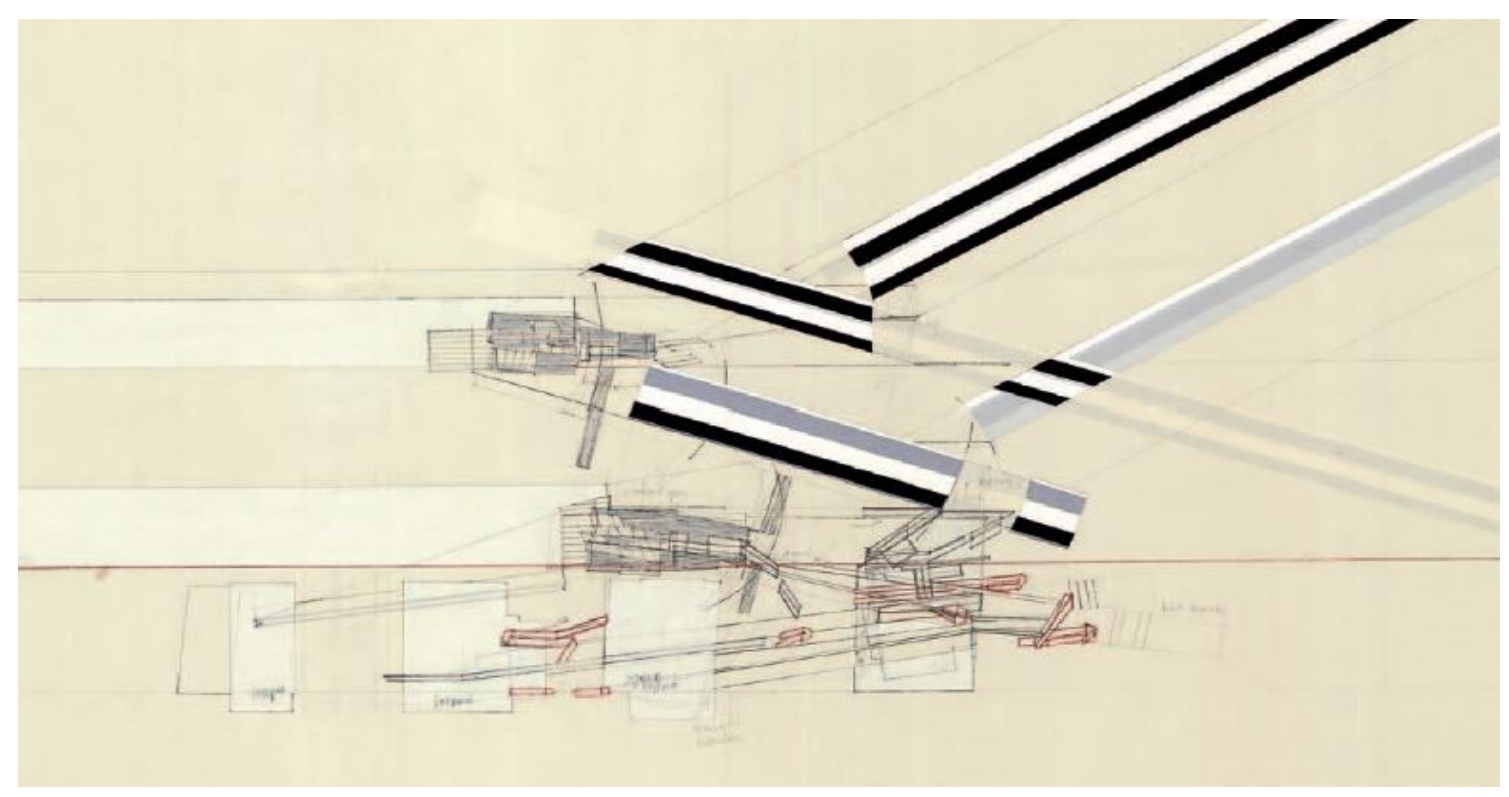

Figure 24 | The village is shown in its inevitable withdrawal from the edge, 2005. Source: Laura Allen, Retreating Village, Image 19, pg. 17

\footnotetext{
50 "The Retreating Village," Smout Allen.
} 
"A mechanical landscape is created of winches, pulleys, rails and counterweights, mimicking techniques for hauling boats from the waves," and allows the landscape to adopt an architectural language of impermanence, contributing to the nature of the restless landscape..$^{51}$

Concepts explored in The Retreating Village stimulate important questions in regards to whether communities should stay and fight against the impending damages brought by floods or whether retreat is the better option. More often than not, communities do not have extra landscape to allocate for flooding —as in the case of coastal realignment - and have few options but to evacuate. Akin to the Harthshorne house moving machine used to relocate the "Lost Villages," Smout Allen's proposal for a mechanical landscape highlights the bleak reality that most villages often have no choice but to retreat from unstable landscapes. It was predicted that the coast of the Norfolk villages would retreat at a rate of five meters per year, resulting in the continued loss of pertinent local infrastructure. This rate of decay is relatively slow however, so a response like a slow mechanical retreat makes sense. Floods on the other hand are fast and will require a faster type of response.

51 "The Retreating Village," Smout Allen. 


\section{4|CASE STUDY NO. 4: WHANGAPOUA - THE SLED HOUSE}

LOCATION: Coromandel Peninsula, New Zealand

WHO: Crosson Clarke Carnachan Architects

YEAR: 2012

The Coromandel beach Peninsula in New Zealand lies within the coastal erosion zone where all buildings must be removable. ${ }^{52}$ Crosson Clarke Carnachan Architects have taken the idea of removability very literally and have designed a home mounted on two thick wooden sleds. The Sled House is a reinterpretation of a typical New Zealand 'bach'—or low budget beach shack..$^{53}$ The house can easily be relocated using a single tractor that slides the house along two sleds back inland or across the beach and onto a barge $\mathrm{e}^{54}$; it can be relocated if erosion or weather conditions require. This architectural project has simplified the concept of relocation down to two components: a sled and a tractor. The designer's did not overcomplicate the machinery required for the structural relocation; their design allows the structure to be moved by one or two people-it does not require an entire team of professionals. The house is permanently built on a mobile foundation making it easy to move the house whenever it requires. The system's simplicity allows for quick deployment, which could be crucial in saving time during moments of urgent retreat.

\footnotetext{
52 "Hut on Sleds," Crosson Architects, http://crosson.co.nz/hut-on-sleds-whangapoua/

53 "Sled House: A House You Can Relocate With a Tractor?," Lunchbox Architect, https://www.lunchboxarchitect.com/featured/sled-house/

54 "Hut on Sleds," Crosson Architects, http://crosson.co.nz/hut-on-sleds-whangapoua/
} 

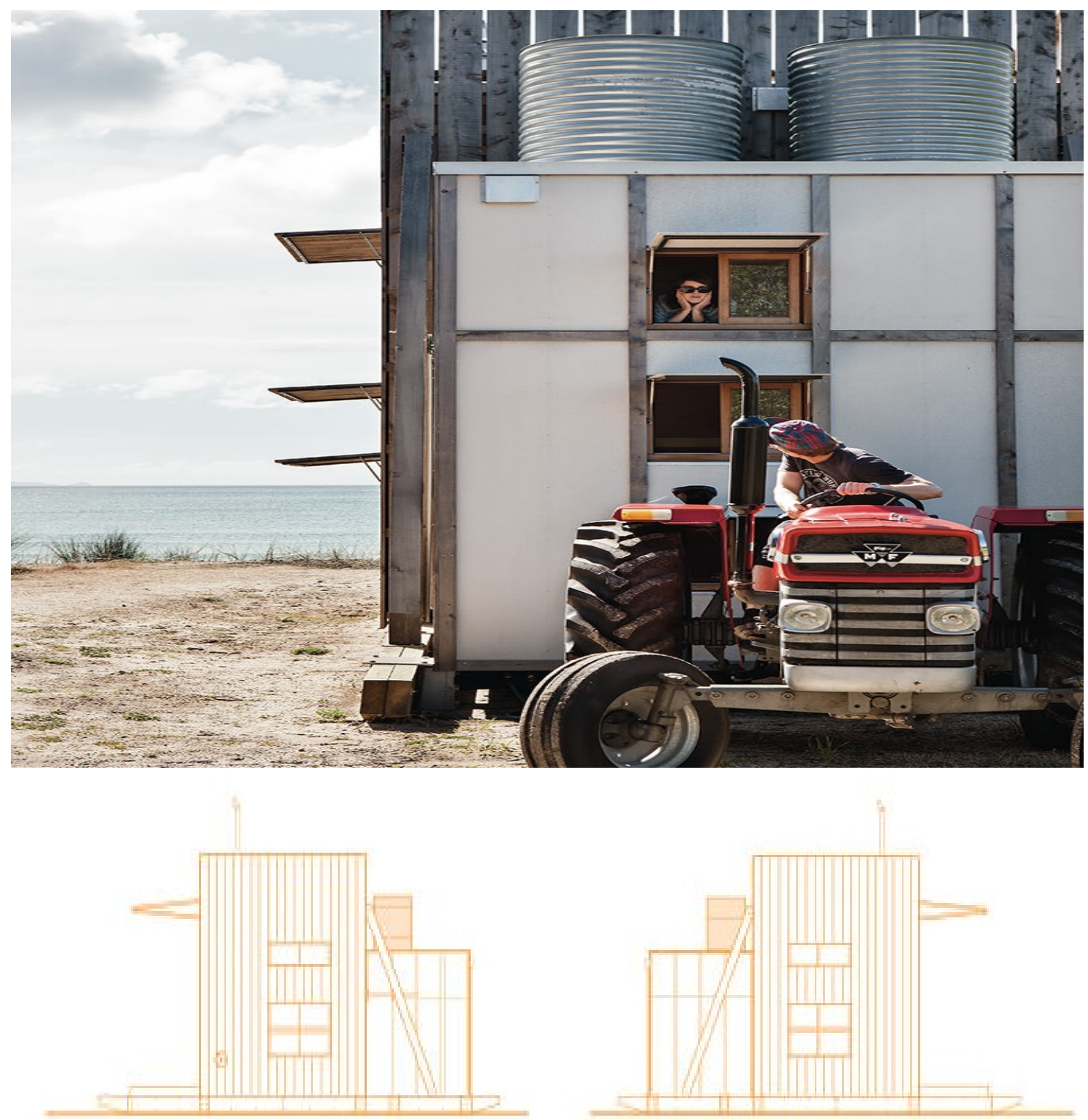

Figure 25 | The Sled House, 2012

Source: Crosson Architects, accessed March 30,2019, http://crosson.co.nz/hut-on-sleds-whangapoua/ 


\section{0| THE FLOOD TOWER NETWORK}

"It is common usage to call "monsters" an unfamiliar concord of dissonant elements: the centaur, the chimera, are thus defined for those without understanding. I call "monster" all original inexhaustible beauty." (J'arry, 33) 
Through a series of architectural strategies, this thesis proposes the design of a two-parted speculative landscape for a Flood Tower and House Moving Network. The first half of the design proposal centers on the concept of warning. The proposal features the design of a network of Flood Towers sited at various intervals along the St. Lawrence and Ottawa River. Beginning immediately downstream of Lake Ontario and terminating where the rivers converge near the Montreal harbour, the Flood Towers located in and on the edge of the river, will take advantage of their site to provide adjacent communities with two main functions. Foremost they will act as visual signal towers that warn communities of impending flooding conditions. Large-scale river gauges will rise through the centre of the tower informing habitants of the ever-changing discharge rates along the river which are invisible to the untrained eye and act as a first sign of potential floods. In the case of observed high discharge levels, littoral communities can begin preparing for the probability of an evacuation. The second half of the design proposal considers the concept of retreat. The proposal includes the design of a mechanical landscape upon which the communities are located. The landscape system consists of a series of I-beam tracks and tractor pulleys that assist in drawing the houses back and away from the rising floodplain. The Flood Towers will include a series of turbines that harness the kinetic energy of the river. The energy will be stored in a back-up power grid to serve littoral communities in need during the realization of a severe flood event. 


\section{1| Architectural Monsters}

In his book Monsters of Architecture, Marco Frascari explains that "the marriages between analogous architectures give birth to hybrids and those hybrids between diverse architectures generate aborts or monsters." ${ }^{55}$ He explores the idea of an architectural monster that is born out of a combination of unlike parts, joined together to create a hybrid structure. Simultaneously Frascari explores the concept of architecture as a means to put something on display "suggesting that the pursuit of architecture is to make visible signs out of that which is invisible." ${ }^{56}$ In this regard, Frascari highlights that architecture has the ability to display things visually that may otherwise have gone unnoticed by the human eye. The design for the Flood Tower network uses this idea of an architectural hybrid —or monsterand capitalizes on its ability to make that which is invisible, visible. As was previously explained, it is pertinent to understand the behaviour of water and its velocity when questioning flooding; the Flood Towers will act as architectural "monsters" to make visible the invisibility of the destructive nature of water.

\footnotetext{
${ }^{55}$ Marco Frascari, Monsters of Architecture: Anthropomorphism in Architectural Theory, United Kingdom: Rowan \& Littlefield Publishers, 1990, 14.

${ }^{56}$ Frascari, Monsters of Architecture, 33.
} 
The following two chapters will outline the "kit of parts" that make up the monstrous hybridity incorporated in the design of the Flood Tower and House Moving Networks. The study begins with the interpretation and design survey of tall structures that have been used in the past as coastal warning towers, information stations or elevated landmarks. The design of each structure is carefully considered and concepts from each have been rethought for use in the design of the network of Flood Towers along the St. Lawrence Seaway. This thesis has criticized modern technologies and information systems and their inability to provide reliable, up-to-date information. Rather than using modern technologies, this thesis has specifically chosen to reuse old towers and machines as the basis for the network design. Machines of the past were designed to make their movements and associations more visible than today's "invisible" movements within contemporary computers and electronic systems. The intent of the Flood Tower Network is to revert back to a simpler method, to provide vulnerable communities with an immediate warning system akin to those of the past. Historically, these coastal towers could not rely on the technology that is available today to relay their information; these structures relied simply on their physical presence- their attributes immediately perceivable by the senses: light, colour, sound and shapeto convey their intended messages. Their presence were immediately perceivable by all passersby, difficult to ignore, and impossible not to see. With reference to the concept of "landmark as tracker", the network of Flood Towers along the St. Lawrence and Ottawa rivers draw inspiration from these historical structure's 
ability to use their architecture as a means of visual recognition. Modern-day electronic delivery systems lack the quality offered by these historic infrastructures; their ability to translate information immediately have a direct impact on the users. The Flood Tower's architectural composition will allow the St. Lawrence's dynamic volume discharges to be rapidly discernible to all community members; no longer will the littoral inhabitants be at the mercy of delayed electronic information systems. 


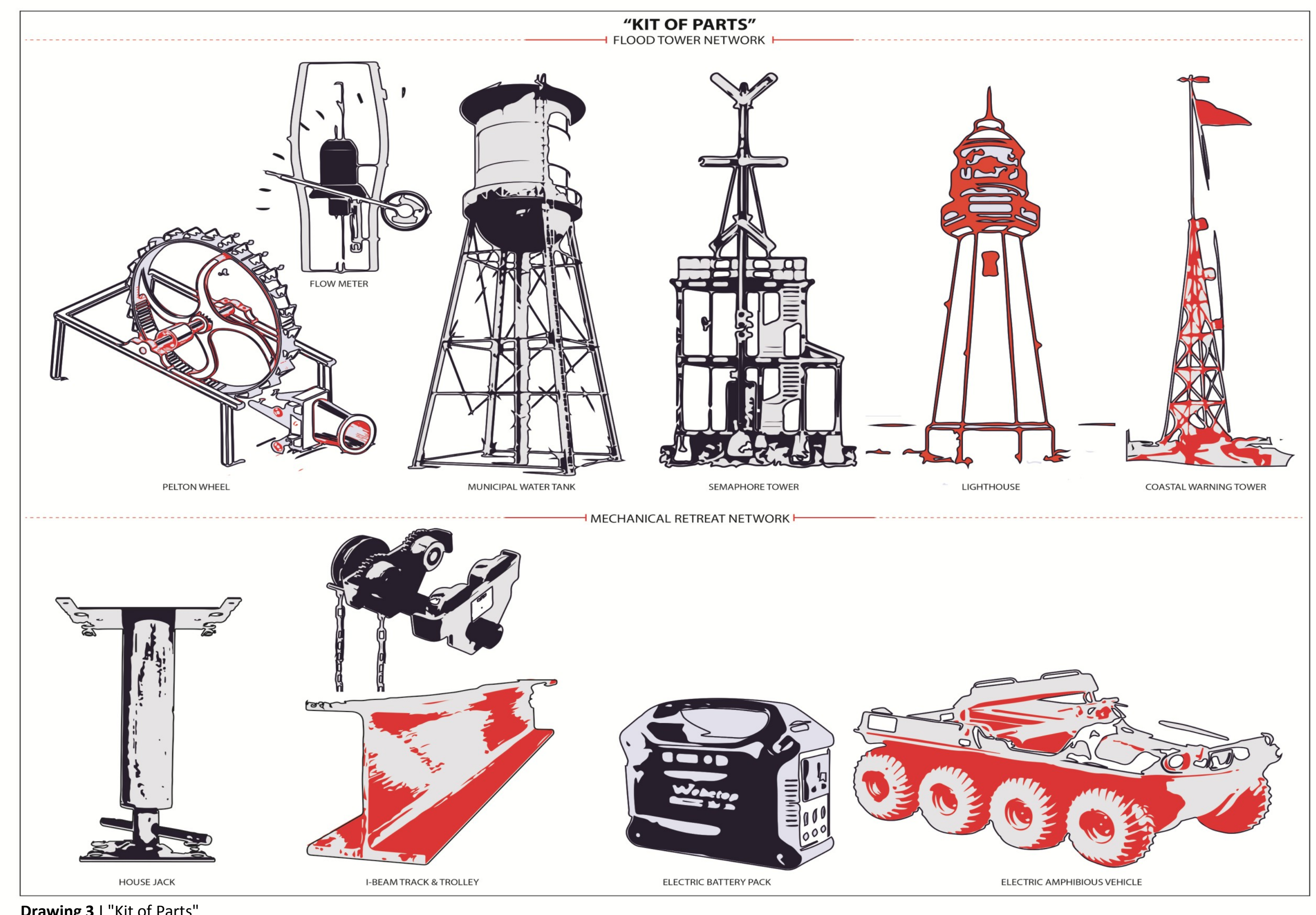




\section{2| The Flood Tower Network}

\subsection{1| The Water Tank}

Rising tall from the ground, overlooking our landscapes and populating our skylines, water towers have been a part of our industrial infrastructure since the midnineteenth century. These high-rise structures store pressurized water in elevated water tanks for the distribution of potable water to communities in its vicinity. Often being the highest point in many cities, water towers are frequently used as

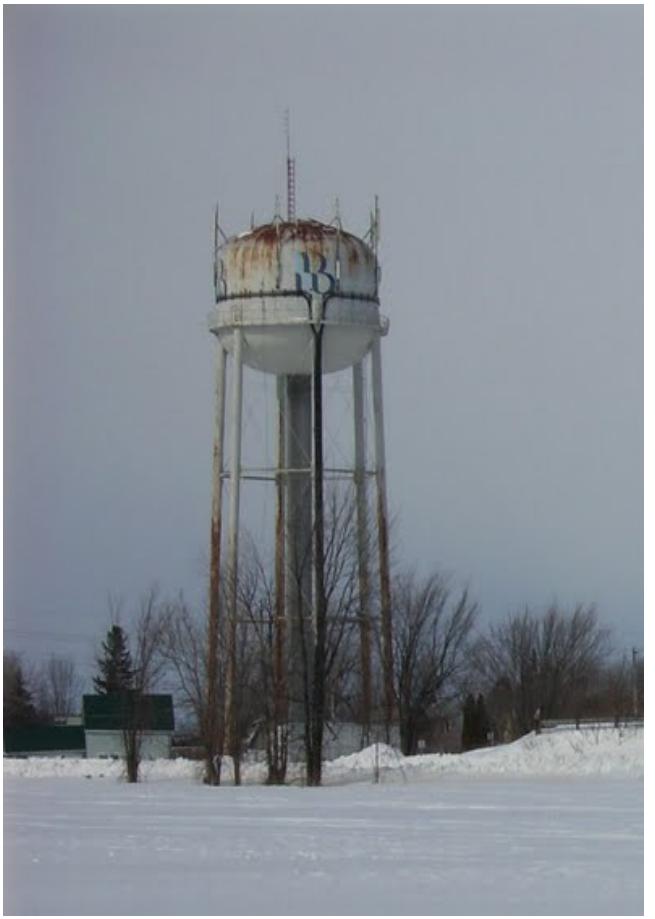

Figure 26 | Beauharnois, Quebec Municipal Water Tower Source: Accessed March 7, 2019, https://www.tripmondo.com/canada/quebec/mont eregie/beauharnois/

backdrops for advertisement or as landmarks. Their spherical or cylindrical reservoirs are iconic in design and are unquestionably recognizable as a symbol of our control of water. To create warning towers, decommissioned water tanks will be relocated to the river and repurposed to form the main element in each of the St. Lawrence Flood Towers. Although no longer serving the purpose of water storage, the Flood Towers will capitalize on the water tank's iconic hydraulic symbolism to draw attention to the importance of these towers as warning stations. 


\subsection{2|The Coastal Warning Tower}

Tall, skeletal coastal warning towers have been used in the past as signal stations to warn mariners and coastal communities of the development of storms in their area. For more than a century, these signal stations were used as a visual warning system by yacht clubs, marinas, and Coast Guard stations who would hoist flags, pennants and coloured lights up the tower.${ }^{57}$ During the daytime, flags would be raised and at night a system of coloured lanters would be used. At the onset of a storm, the National Weather Service would alert the stations to raise their signals, and once the threats passed, the signals were then lowered. The towers were designed to provide an array of alerts, and often included advisories for small crafts, wind, gale, storm, and hurricane warnings.

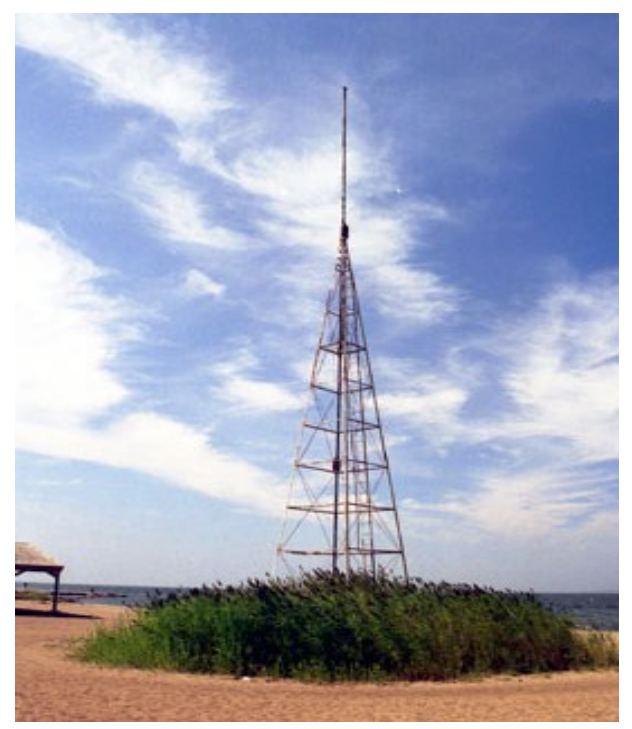

Figure 27 | Coastal warning display tower from 1898, New Haven CT

Source: Jeremy D'Entremont, , Ibiblio accessed March 5, 2019,

https://www.ibiblio.org/lighthouse/storm_warnin g_towers.htm

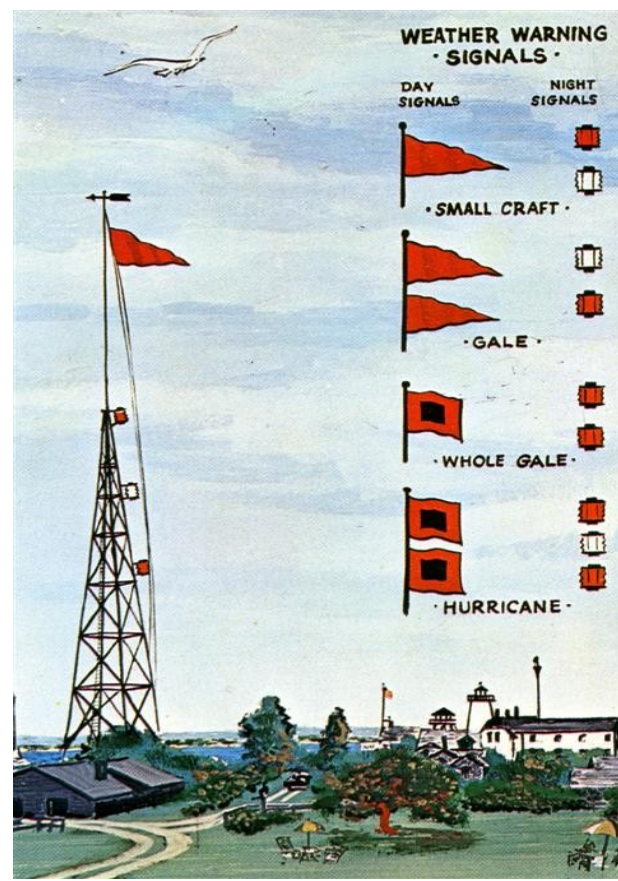

Figure 28 | Storm Signal Diagram, 1898

Source: Accessed March 5, 2019,

http://www.hatteras.biz/joomla/blog-top/78-coastalwarning-display-towers

\footnotetext{
57 "National Weather Service Marine Forecasts: Coastal Warning Display Program." National Oceanographic and Atmospheric Administration. Last modified November 18, 2014. https://www.nws.noaa.gov/om/marine/cwd.htm
} 
The National Service retired its Coastal Warning Display network on February 15, 1989 in favour of real-time telephone recordings and NOAA Weather Radio reports..$^{58}$ Lamentably, much like the hydrometric data stations located along the St. Lawrence Seaway, the transmission of telephone recordings often results in the public's delayed receival of information. The coastal display stations allowed communities access to an immediate visual advisory of impending storms.

\subsection{3|The Lighthouse}

Sited on the edge of coastlines, lighthouses have played an instrumental role in marine history serving as navigational tools for seafarers and navigators alike. Through a system of lamps and lenses, the sky-high structures illuminate dangerous shorelines, risky shoals and indicate safe points of entry and disembarkment. In their early days, lighthouses were primarily used to spotlight points of entry into harbours, but through advancing technologies, these structures are more commonly used to provide visible warning against shoreline threats to incoming ships. A lighthouse can easily be identified from sea by its distinctive shape, by the colour or flash pattern of its light, or by the coded pattern emitted by its radio signal. ${ }^{59}$ Lighthouse stations comprise many infrastructural components, including the tower that elevates the lantern room where the lighting system is located.

\footnotetext{
58 "Coastal Warning Display Program," NOAA.

${ }^{59}$ lan C. Clingan, "Lighthouse," Encyclopaedia Britannica, last updated March 5, 2019,. https://www.britannica.com/technology/lighthouse
} 
The fully glazed lantern room at the top of each tower houses the lighting system used to emit the warnings. Most modern lighthouse lens systems today use a series of lamps and lenses, referred to as the Fresnel catadioptric system, ${ }^{1}$ to radially emit their signal. Inspired by the coastal warning station's system of flags and pennants and a lighthouse's lens configuration, each Flood Tower will use a night time lighting system and a daytime flagging system to warn communities of the developing flood conditions.

\subsection{4|The Semaphore Telegraph}

In the eighteenth-century

communities relied primarily on post-riders

— a postal delivery system operated by a horse and rider — to deliver information across long distances of land. In France in 1794, Claude Chappe developed the design

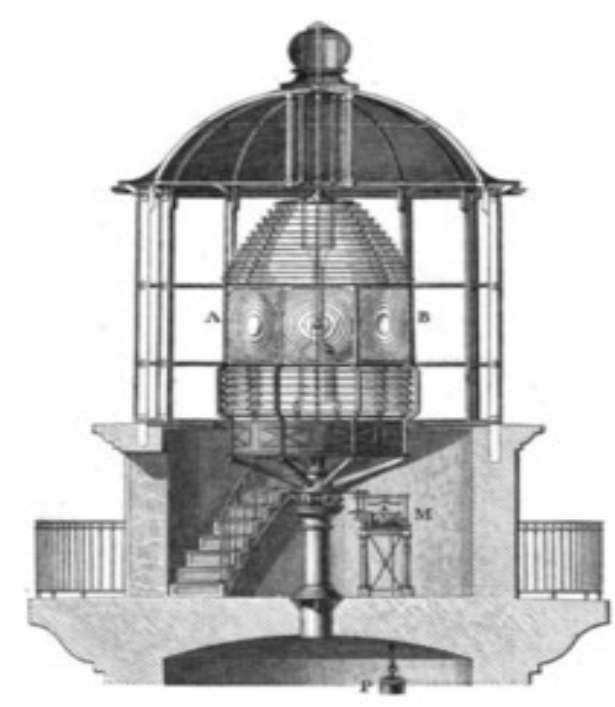

Figure 29 | Lighthouse Lenses, 1759

Source: Figure in Adolphe Ganot, Natural Philosophy for General Readers and Young Persons, (New York: D. Appleton \& Co., 1872) p.329, fig. 258.

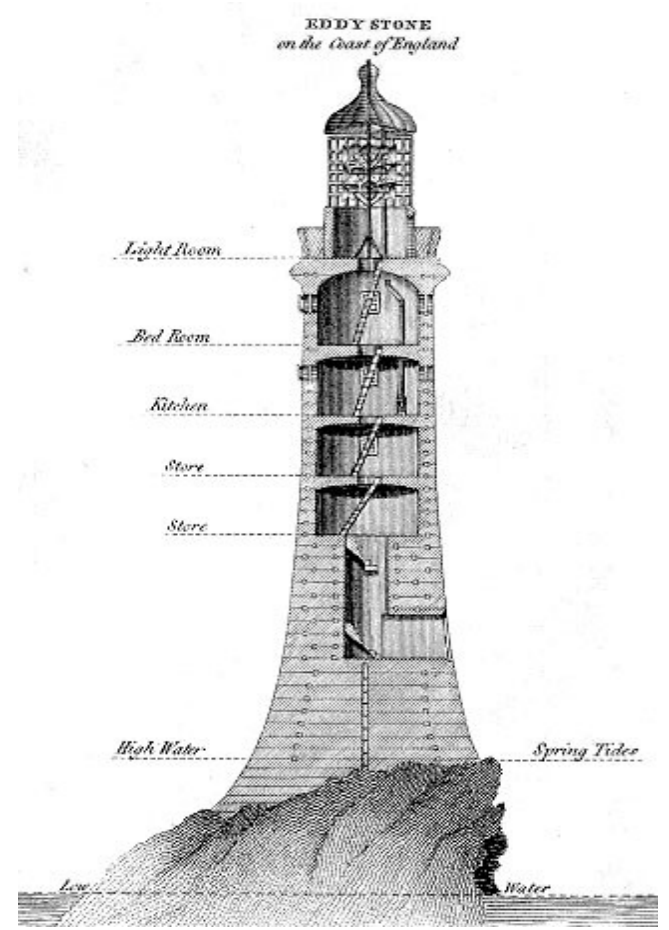

Figure 30 | John Smeaton's rebuilt version of the Eddystone Lighthouse, 1759

Source: Accessed March 7, 2019, http://www/wilsonbenesch.com/newsblog.html 
for a semaphore tower, also known as an optical telegraph, that would facilitate and streamline the delivery system. ${ }^{60}$ Through a series of pivoting shutters, blades or paddles raised high into the air, semaphore towers were designed as a method of visual signaling to relay information across long distances. A sequence of stations were arranged so they could easily be seen by the next tower in the line of succession. Each semaphore tower was managed by a single operator who would closely observe the watchmen of the neighbouring towers in preparation of relaying information. The operators would pivot the mechanical shutters to spell out messages in semaphore code; once in a fixed position, the code could be read.

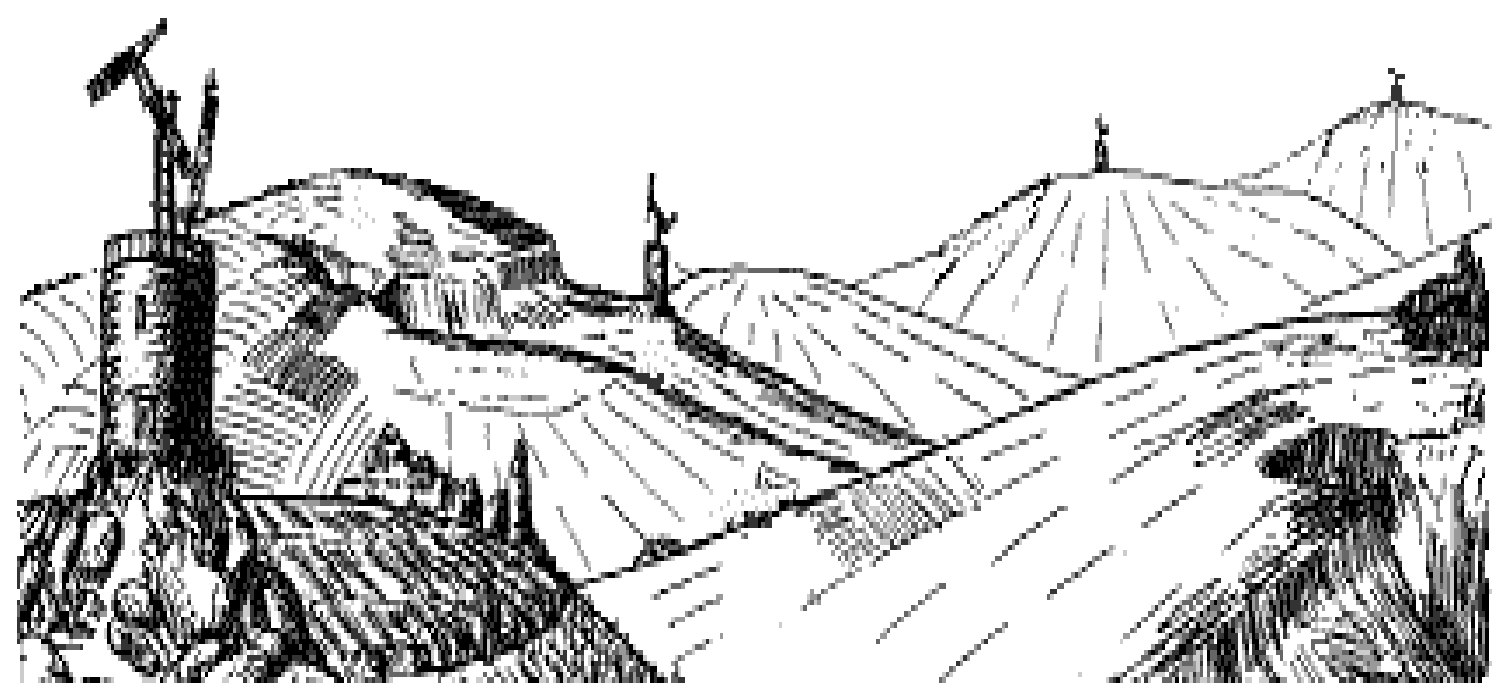

Figure 31 | The Chappe Telegraph System, 1792

Source: accessed March 7, 2019, http://www.telegraphe-chappe.com/chappe/resume.html

\footnotetext{
${ }^{60}$ Richard Pallardy, "Semaphore Communications," Encyclopaedia Britannica. https://www.britannica.com/technology/semaphore
} 
Although mostly discontinued, modern adaptations of the semaphore continue to be used today in the marine, air and railway transport industry. As explained in greater detail in the following section, a key feature of the Flood Tower will be a large gauge needle that shifts its position along a scale to indicate the discharge rate of the river. Akin to the paddle system used by the semaphore telegraph, these gauge needles will be legible from great distances.

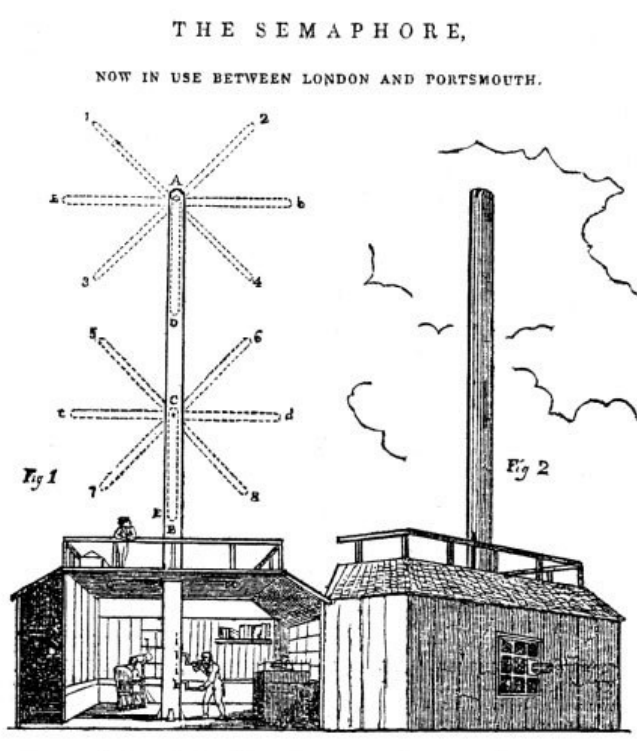

Figure 1.5 A London-Portsmouth semaphore station Source: Mechanic's Magazine, 24th September 1825

Figure 32 | A London - Portsmouth semaphore station, 1825

Source: Figure in Ken Beachamp, History of Telegraphy, (London: The Institution of Engineering and Technology, 2001), pg.11, fig. 1.5 .

\subsection{5| The Flow Meter}

A rotameter is an industrial flow meter used to measure the flowrate of liquids and gases. ${ }^{61}$ The instrument consists of a tapered glass tube with a weighted float inside. The force of the water flow through the tube causes the float to rise and fall according to flowrate; increases in flow cause the float to rise, and decreases in flow cause the float to lower. This device does not require electrical power to operate as it capitalizes on the mechanical nature of water to yield its rating. The mobile float includes a magnet follower system that corresponds to a graduated

\footnotetext{
61 "Rotameters: Introduction to flow Measurement with Rotameters," Omega, published August 8, 2018, https://www.omega.ca/en/resources/rotameters
} 
scale. The flowrate of the liquid passing through the tube can be read based on the needle's position on the scale. The rotameter has been chosen as the flowmeter device for use in the Flood Tower as the glazed tube design enables a visual reading of the corresponding flowrate. The rotameter's optical characteristics will allow pedestrians in its vicinity to easily read the needle's position on the scale,

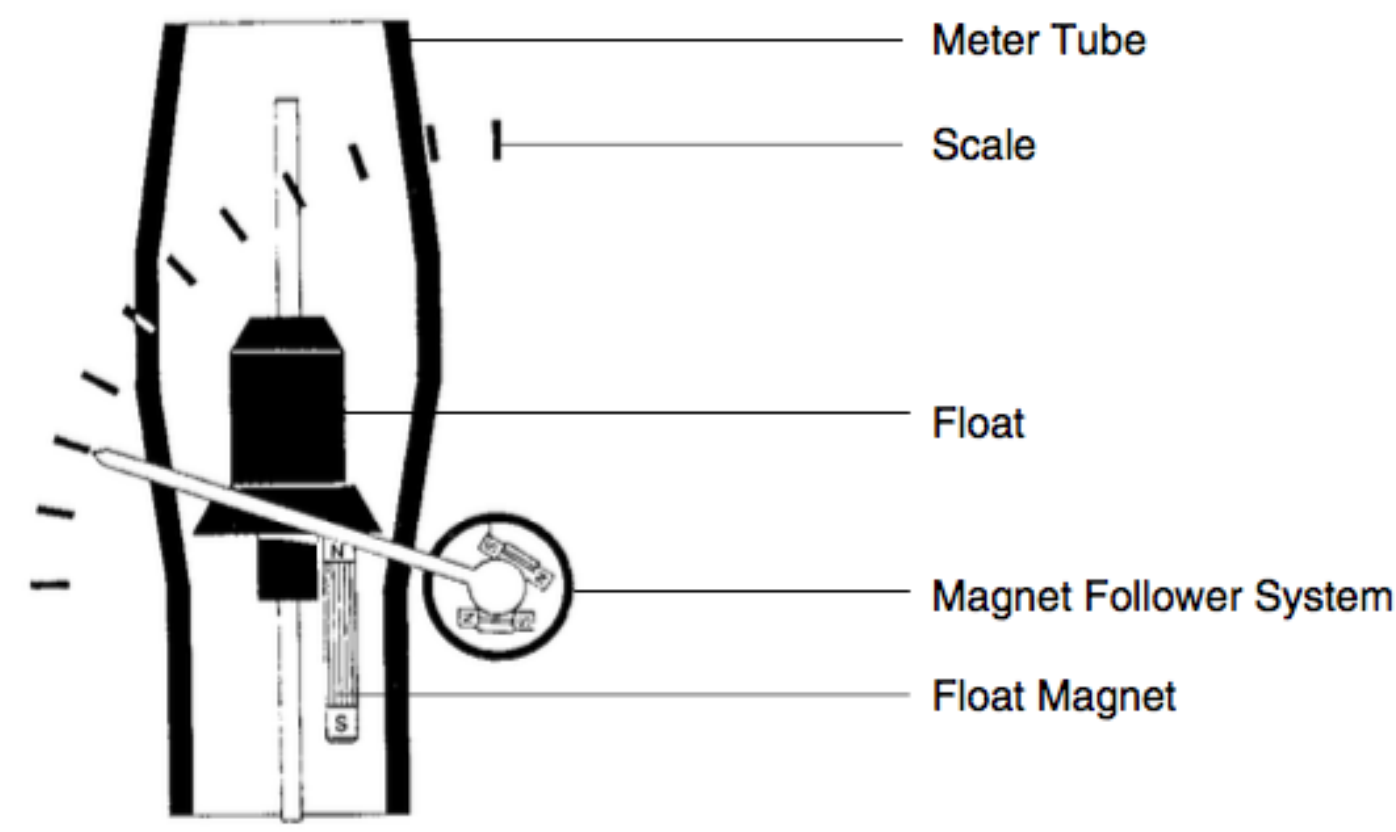

Figure 33 | Components of a Variable Area Flowmeter

Source: The Teco Process Control Blog, accessed March 8, 2019, https://blog.teco-inc.com/search?updated-max=2017-01-30T20:40:0008:00\&max-results=7\& reverse-paginate=true

and will provide them with an instant understanding of the river's discharge rate. It is important for the Flood Towers to provide an "instant" reading of the river's flowrate/discharge because this allows communities ample time to prepare before the flood arrives. It is this lack of instantaneous communication that is missing in our current flood warning systems. 


\subsection{6| The River Turbine}

The Flood Tower will use a series of river turbines to generate renewable energy that will be stored on-site as back-up power to serve downstream communities in the case of severe flooding. River turbines can be placed in a river channel to convert the kinetic energy of the flowing water into electrical energy that can be stored in a grid. The design for the Flood Tower's turbines was inspired by Lester Allan's Pelton Wheel; unlike typical overshot water wheels that use the dead weight of water to extract energy, a pelton wheel harnesses it's energy from the impulse of moving water that passes through it. ${ }^{62}$ A pelton turbine uses simple, bucket-shaped blades to capture the passing water that sequentially rotates the internal rotor of the turbine. Each Flood Tower incorporates four large turbines that are located at the base of the tower, sitting half-way into the river. As the St. Lawrence flow passes underneath the Towers, the turbines capture the water and harness it's energy. The Towers are harnessing the "problem" of the water — the powerful force that causes devastation-to generate energy that is a major loss in floods; in this regard, the problem thus becomes part of the solution. The architecture of the Towers serve to visibly display the water flow passing underneath them. Typically water flow is left imperceptible, but the Towers use their turbines to guide the flow up through the glass flow meter; they take the invisible and presents it in a corporeal, experiential and spatially engaging way.

\footnotetext{
${ }^{62}$ Jordan Hanania, Kailyn Stenhouse, \& Jason Donev, "Pelton Wheel," Energy Education, last updated September 3, 2015, https://energyeducation.ca/encyclopedia/Pelton_turbine
} 


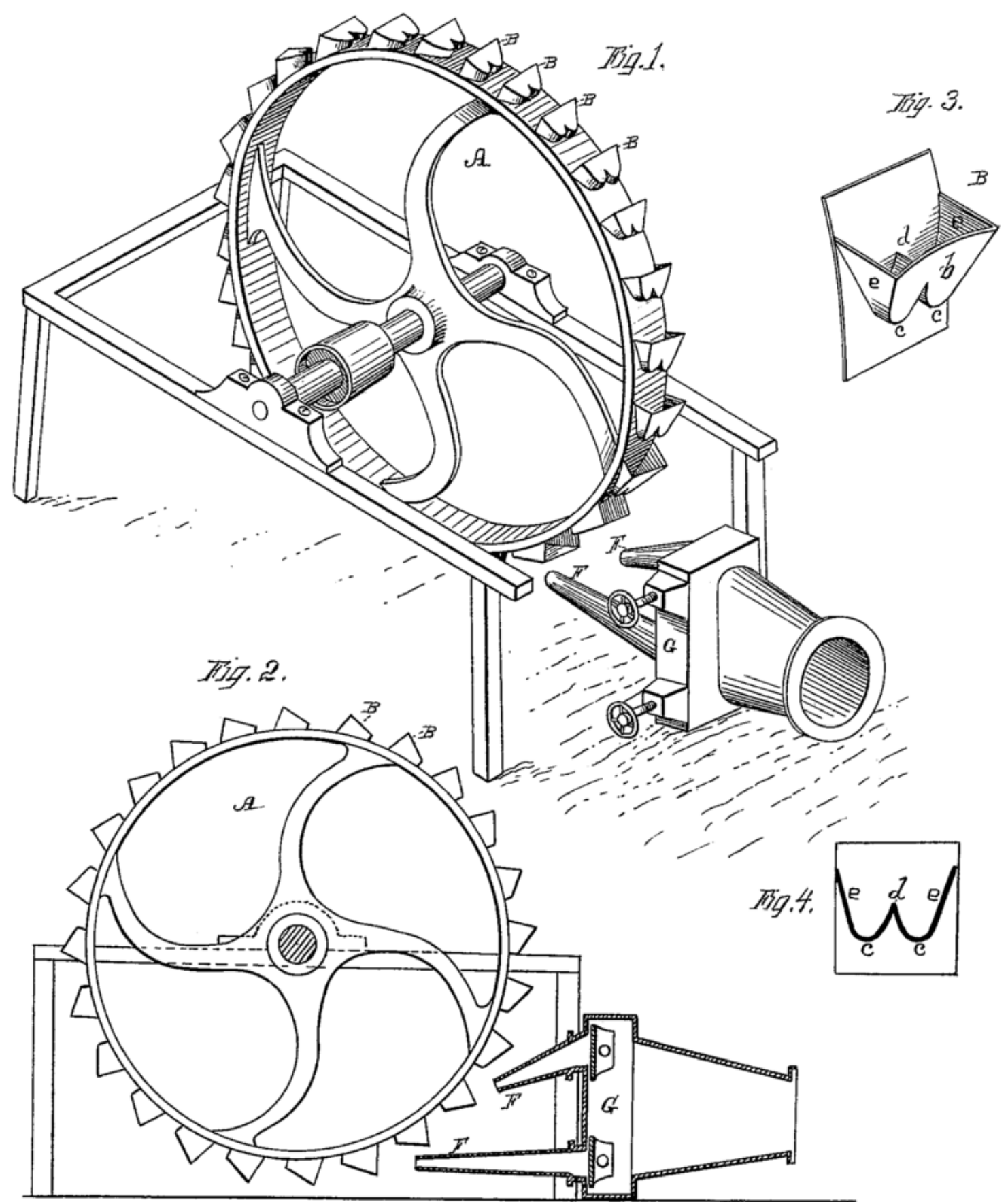

Figure 34 | Pelton Wheel, October 1880

Source: L. A. Pelton, Figure from Pelton's original paten, US Patent 233692, pg.1 


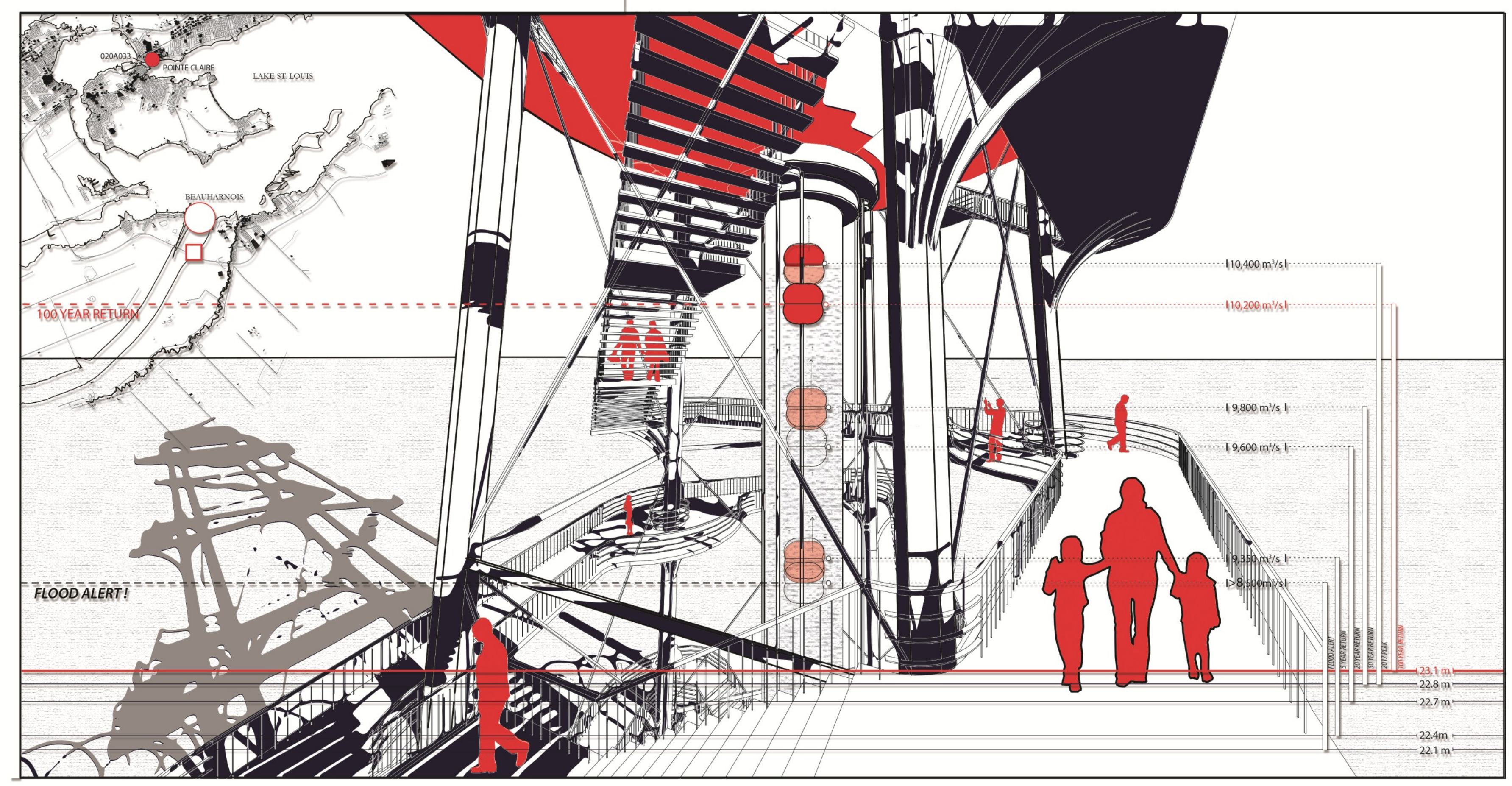

Drawing 4 | Water Tower - Perspective from the Viewing Platform 


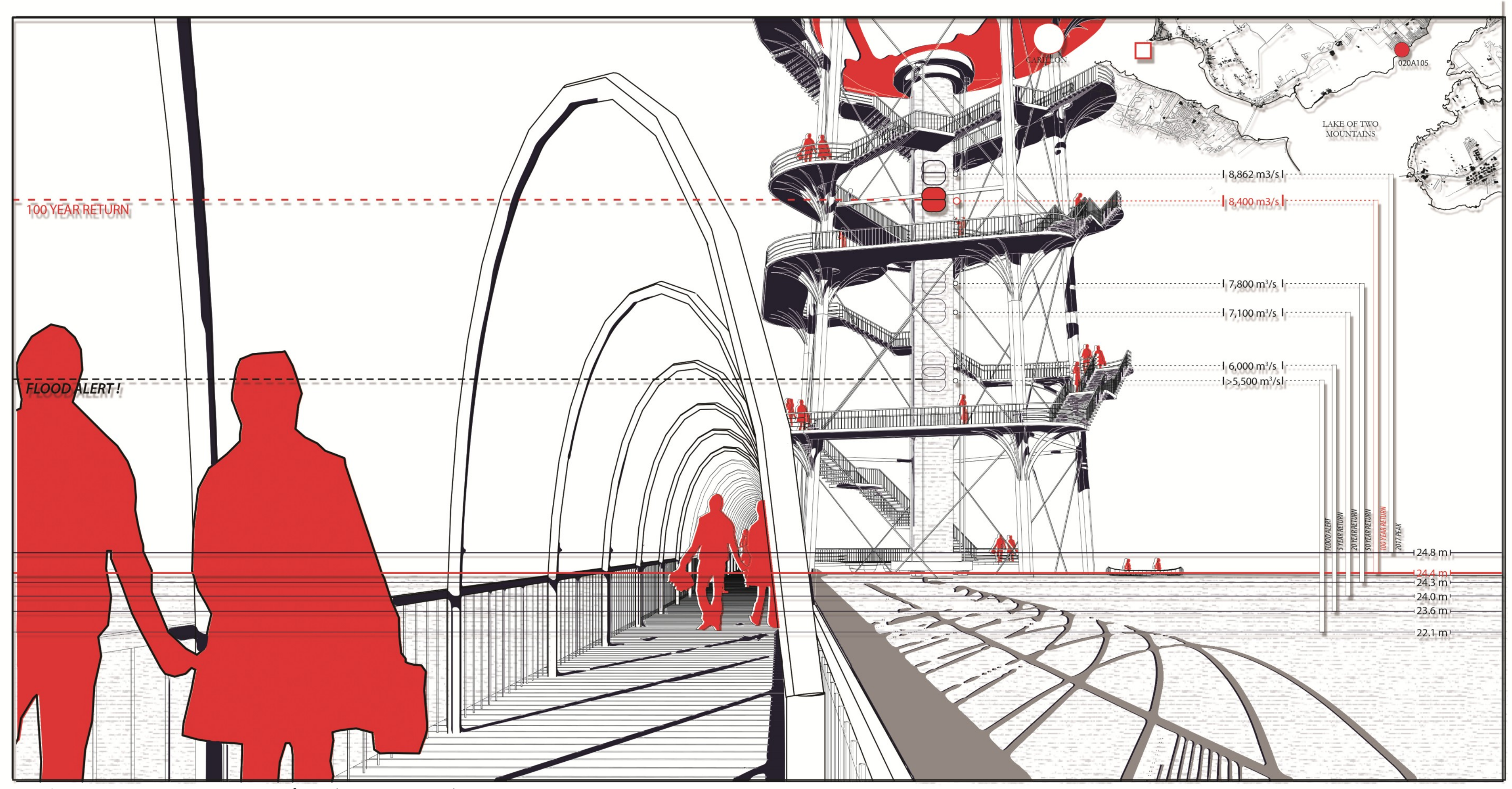

Drawing $\mathbf{5}$ | Water Tower - Perspective from the Entrance Dock 


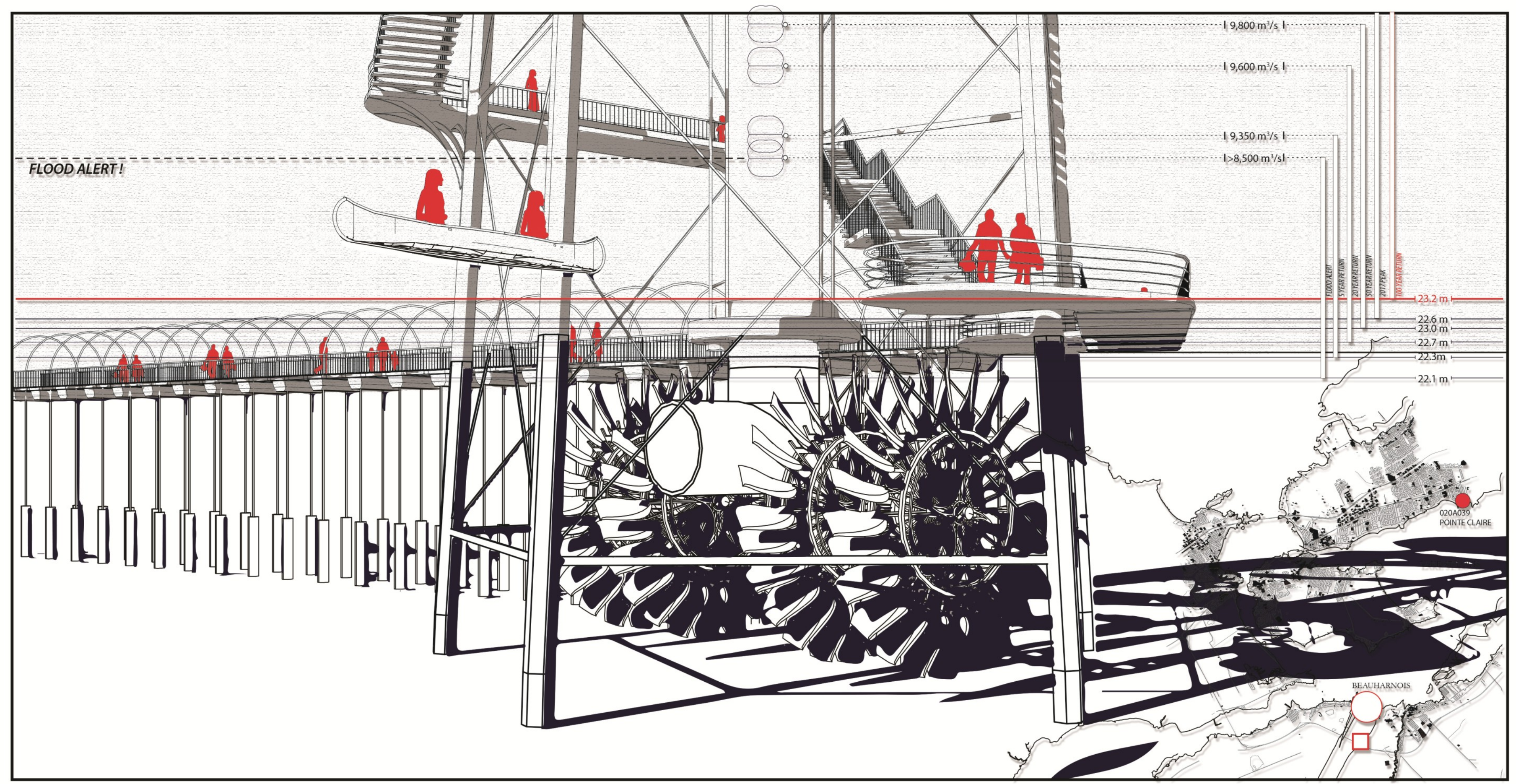

Drawing 6 | Water Tower - View of River Turbines from Underwater 


$$
2
$$




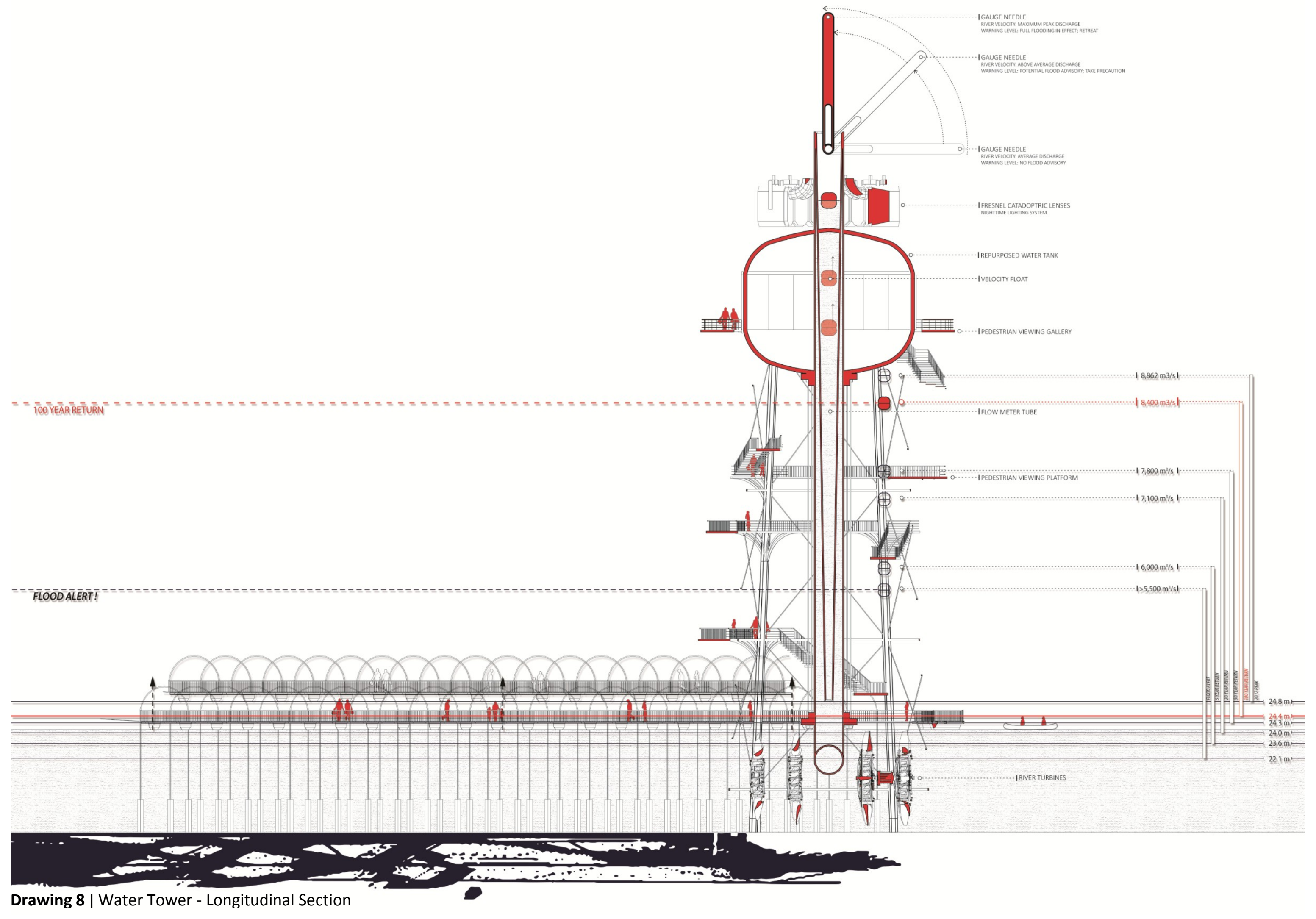



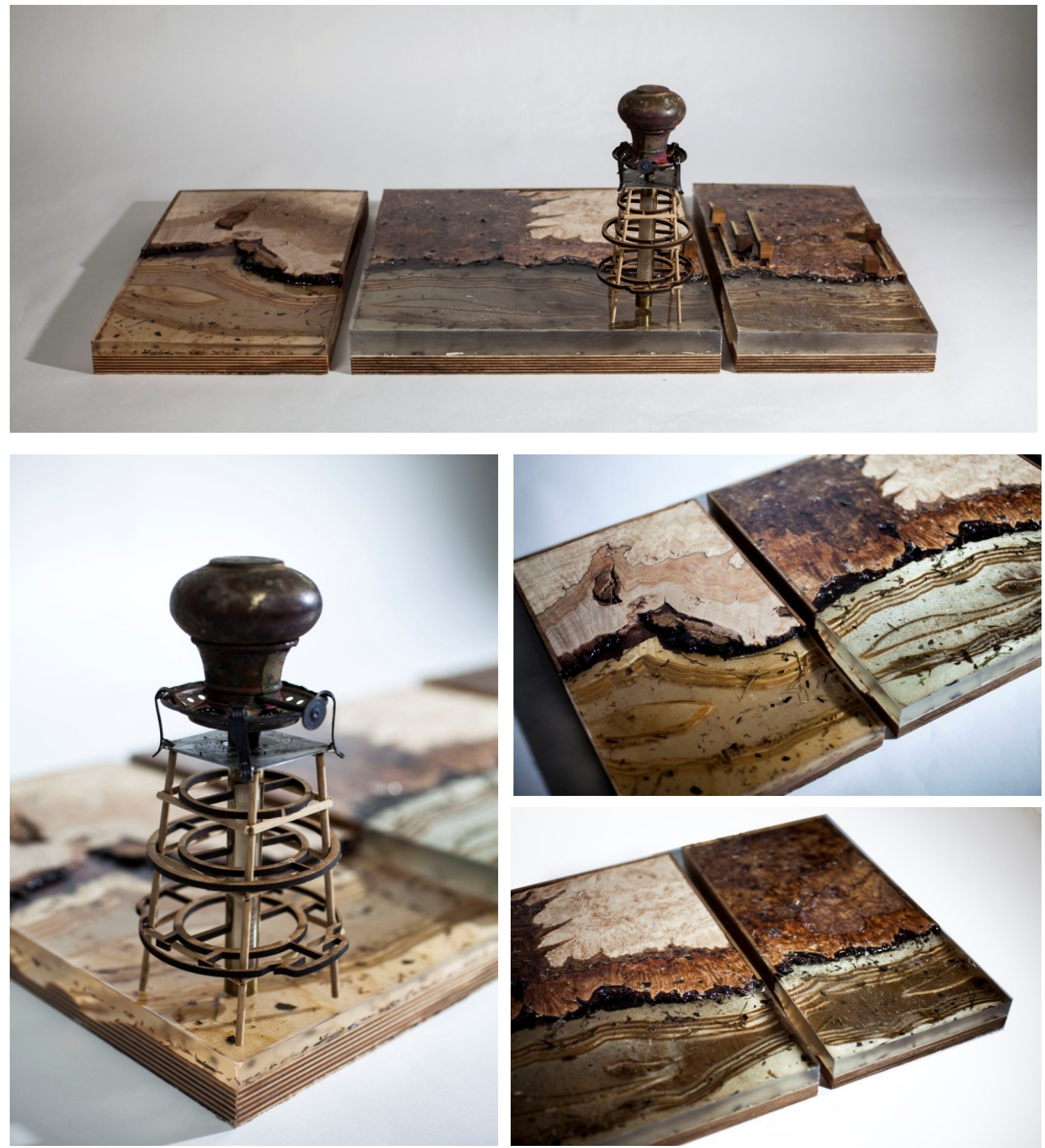

Drawing 9 | River Site Model - Epoxy Resin on Spalted Maple

The above images highlight a site model of the St. Lawrence Seaway cast out of resin. The model intends to "freeze the process of flooding in time" by capturing the conditions of flooding in a three-parted series - the pre-flood, the flood, and the after flood. The model features a "monstrous" Flood Tower assembled out of repurposed components - a doorknob comprises the water tank, an oil lantern switch comprises the viewing platform, and pieces of discarded laser cut models comprise the skeletal body. 


\subsection{The House Moving Network}

In the future, if river

discharge rates reach similar

peaks observed during the

flooding of May 2017, it can be

assumed that the communities

hardest hit-if they remain in

the same location—will suffer

the same damage and loss as

before. The second half of this

design proposal features a

House Moving network of steel

beams, pulleys, and an

amphibious tractor that enables

the communities to

mechanically withdraw their

homes from the dangers of the

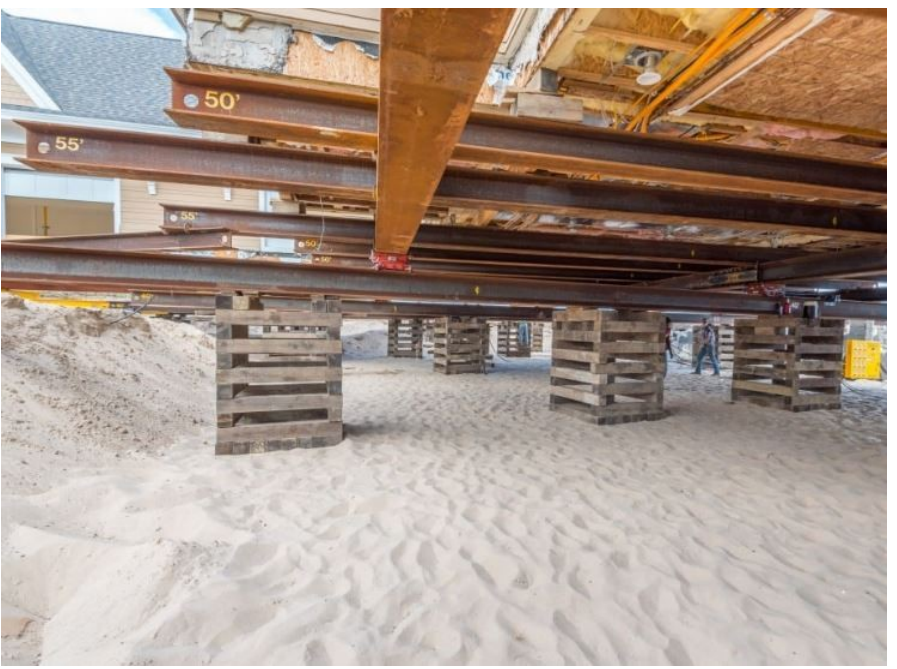

Figure 35 | Foundation Cribbing, St. Joseph, 2015

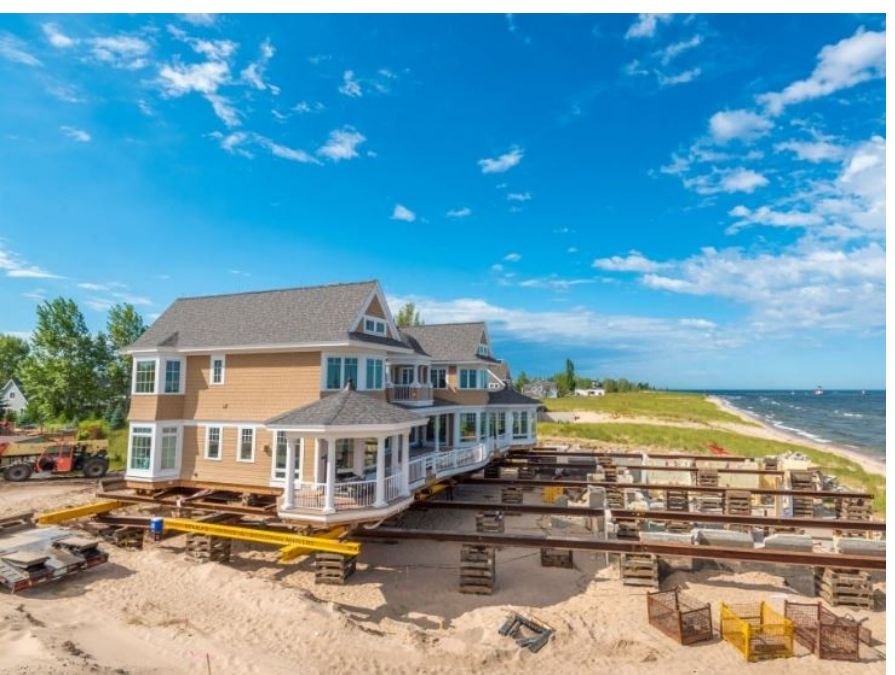

Figure 36 |House Relocation, St. Joseph, MI, July MI, July 2015

Source: Wolfe House Building Movers, accessed March 30, 2019, https://www.wolfehousebuildingmovers.com/project/ floodplain. 


\subsection{1| Lifting}

In order to move back the

houses out of the floodplain, we

must look at the stages involved in a

house relocation. The house must

first be lifted off its foundation and

must then have a series of steel

supports installed underneath. After

the initial lift the house must then be

relocated to its new home and

lowered onto its new foundation.

The process begins by excavating

around the house several feet below

the sill plate. Break holes are cut

directly into the foundation walls

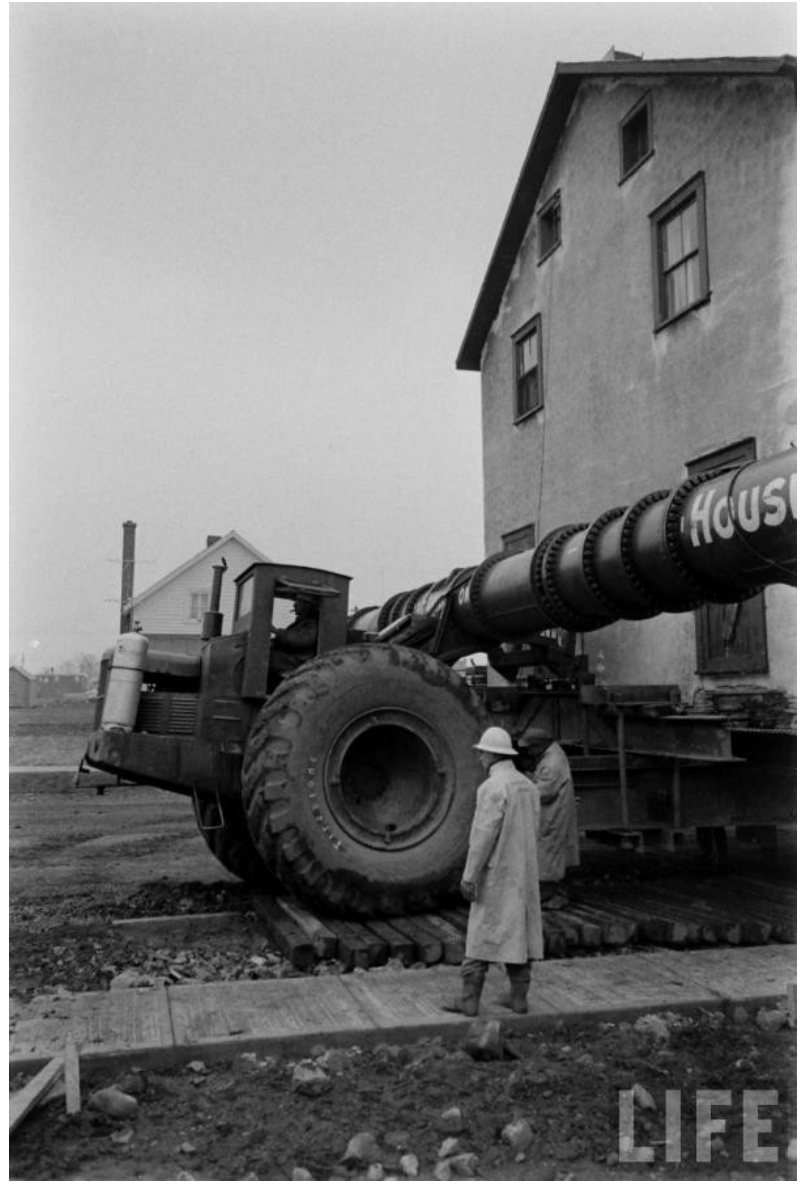

Figure 37 | Hartshorne House Mover, 1958

Source: Figure from Life Magazine, posted in American Truck Historical Society General Archives: What am I, posted March 7, 2011, http://forums.aths.org/PrintTopic111979.aspx

where two main steel beams are inserted; a secondary series of steel support beams are then placed perpendicularly to these main supports at 4 to 5 foot intervals. ${ }^{63}$ Wooden cribbing is then shimmed up underneath all the main weight bearing points of the foundation, allowing hydraulic jacks to be installed underneath. The entire unit is then jacked up off the ground and is ready to be moved.

\footnotetext{
${ }^{63}$ Wolfe House Building Movers, accessed March 30, 2019, https://www.wolfehousebuildingmovers.com
} 


\subsection{2| Moving}

Throughout history there

have been a number of different

machines used to relocate structures.

As was previously explained, the

houses of the "Lost Villages" were

relocated using the Tournamover,

also known as the Hartshorne

House Moving Machine. The power

unit at the front of the Tournamover

was called a Tournapull and was

used to drive the unit. ${ }^{64} \mathrm{~A}$ large pipe

crossing the front of the machine

was the main cross member used to

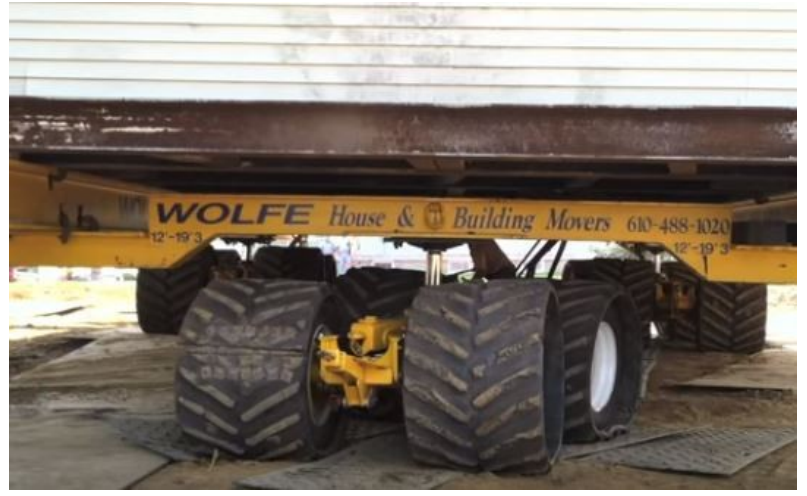

Figure 38 |Hydraulic Dolly Underneath Relocated Foundation

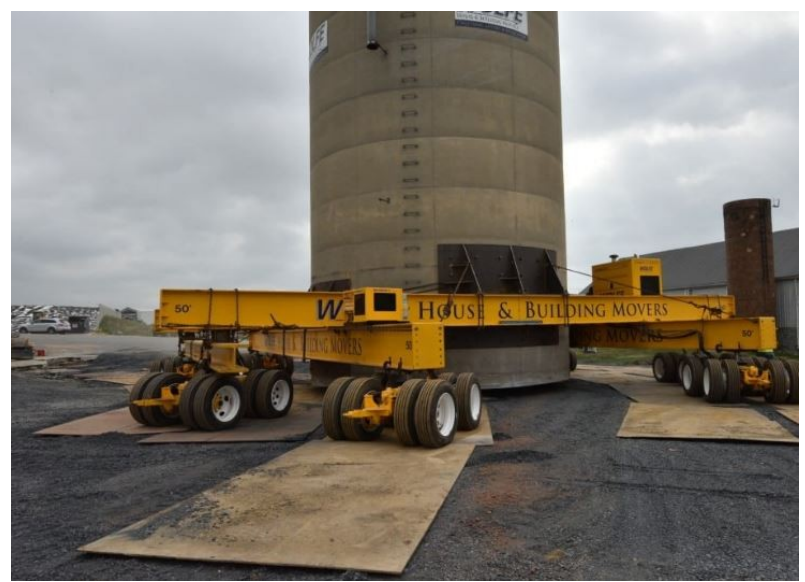

Figure 39 |Hydraulic Dollies

Source: Wolfe House Building Movers, accessed March 30, 2019, https://www.wolfehousebuildingmovers.com

reduce torque in the machine. ${ }^{65}$ This

massive machine was hooked up to the lifted house and was driven to its new

location. Changes and upgrades have been made to the Tournamover design;

today's leading relocation specialists have redefined the machinery required to

move a house. They use a series of smaller, more refined machines — referred to as

a dolly system — to accomplish their relocations.

\footnotetext{
${ }^{64}$ Dale Hardy, "General Archives: What am I," American Truck Historical Society, posted March 7, 2011, http://forums.aths.org/PrintTopic111979.aspx

65 "General Archives," American Truck Historical Society.
} 


\subsubsection{The House Moving Network}

This thesis proposes the design for a new type of house moving network. Just as the design for the Flood Towers were a hybrid design inspired by old, historic towers and modern-day river technology, the House Moving network uses aspects from both the historical Tournamover and the modern hydraulic dolly system as inspiration. Inspired by Crosson Architect's Sled House simplistic design of tractor + sled, the network aims to provide a simple solution to St. Lawrence communities who may need to retreat from the floodplain. Due to the likelihood that the St. Lawrence houses will need to be relocated during a flood, a new machine - able to function in water - will be required to pull the houses out. Known as the Tractor Raft, this machine will be an amphibious vehicle able to maneuver on both land and water. The Tractor Raft is an electric machine that uses the back-up energy generated by the Flood Towers to operate. Unlike the Tournamover, the Tractor Raft has been designed with the average homeowner in mind; they are much smaller and more akin to a typical tractor easily maneuvered by a single individual.

The network will involve a series of steel beam sleds that can be laid in a track underneath the houses after they have been jacked up. Ball-bearing supports attached to the bottom of the structure will enable the house to glide along the tracks. Tractor Rafts will be clipped to the houses and will pull them out of the 
flood zone. The tracks that are a laid can remain in place or can be picked up and used again. As it is difficult to determine the frequency and magnitude of future flooding events, the mobility of the tracks will be pertinent in allowing communities the opportunity to continue retreating. 


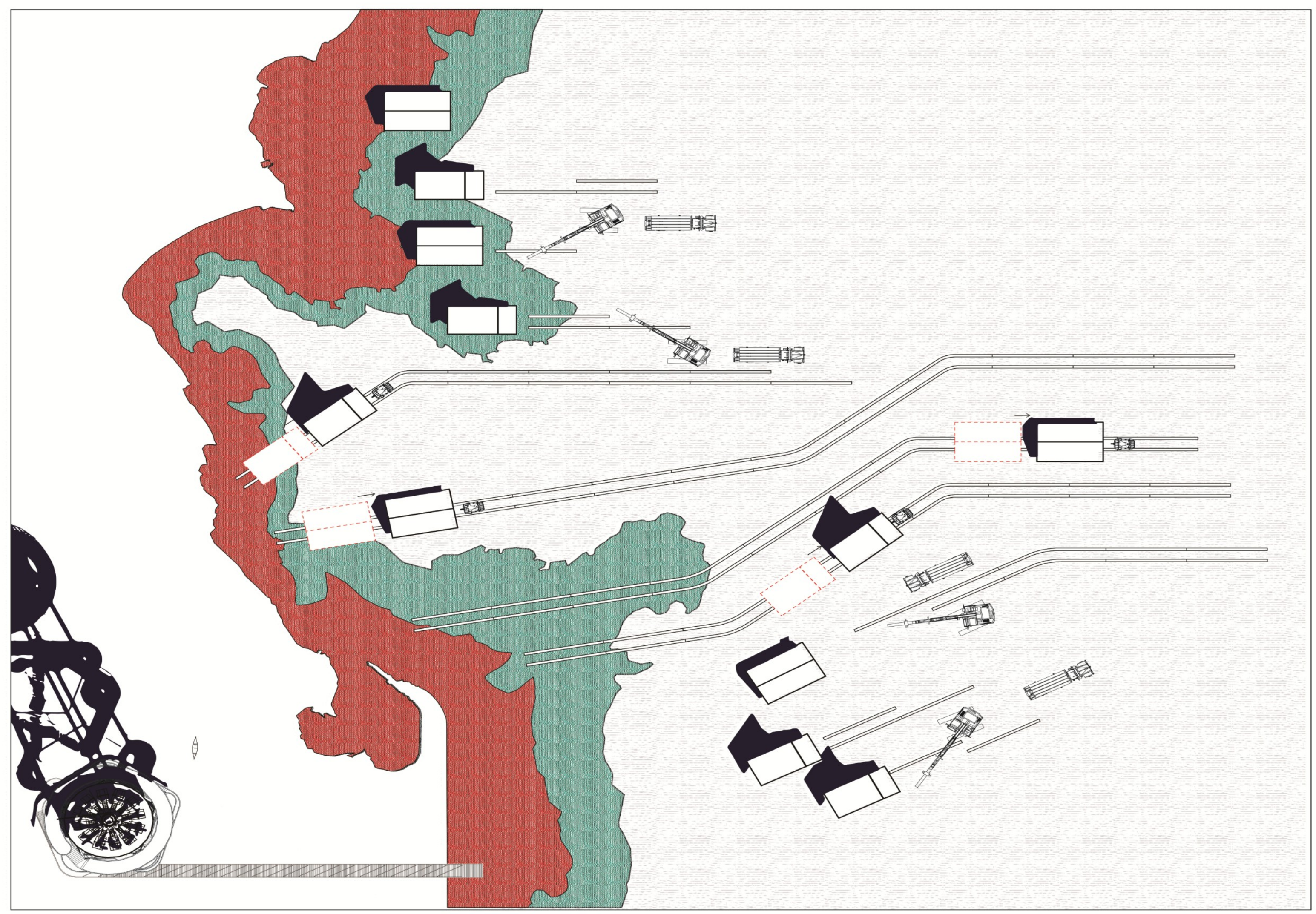

Drawing 10 | House Moving Network - Plan 


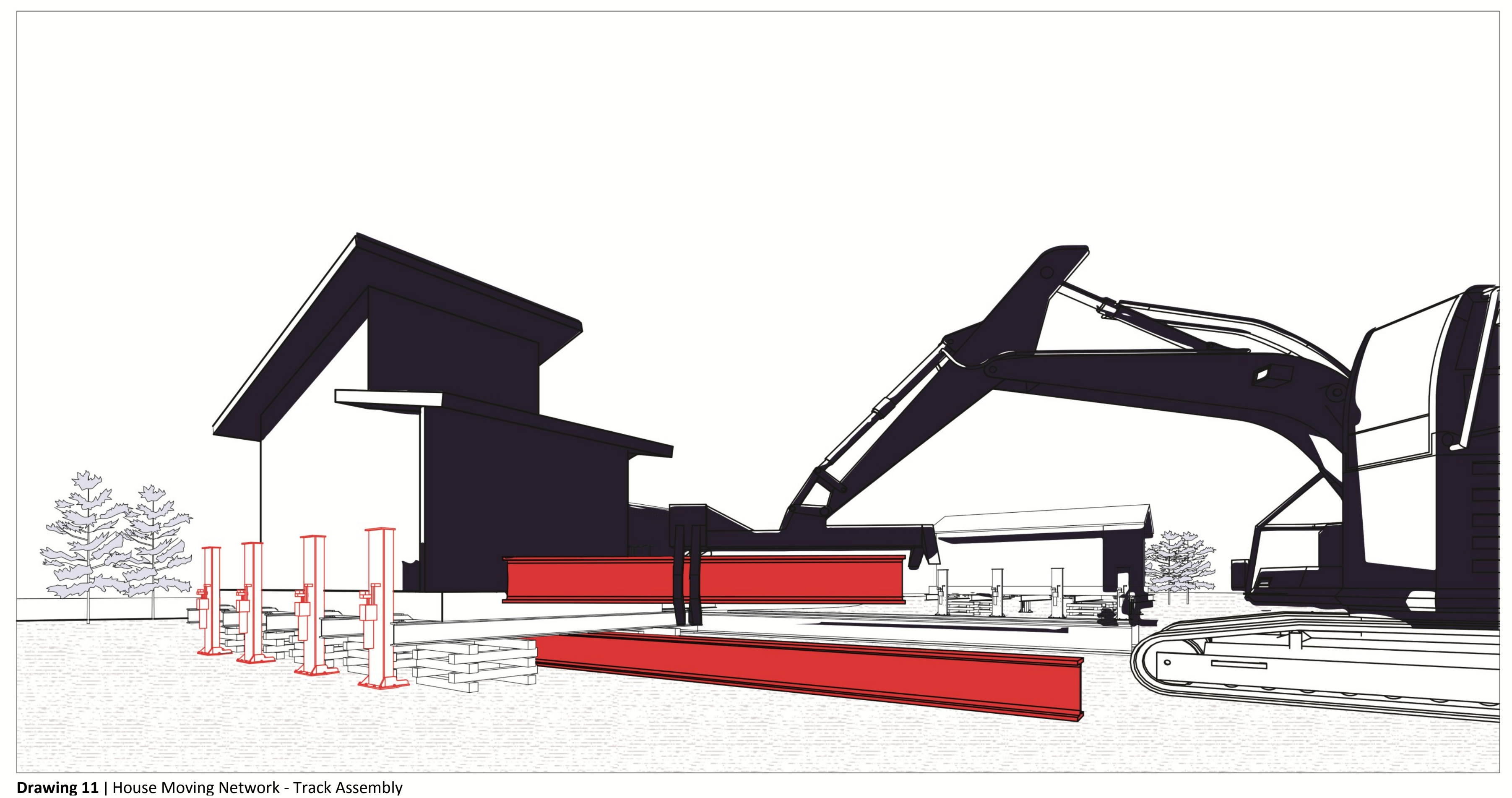




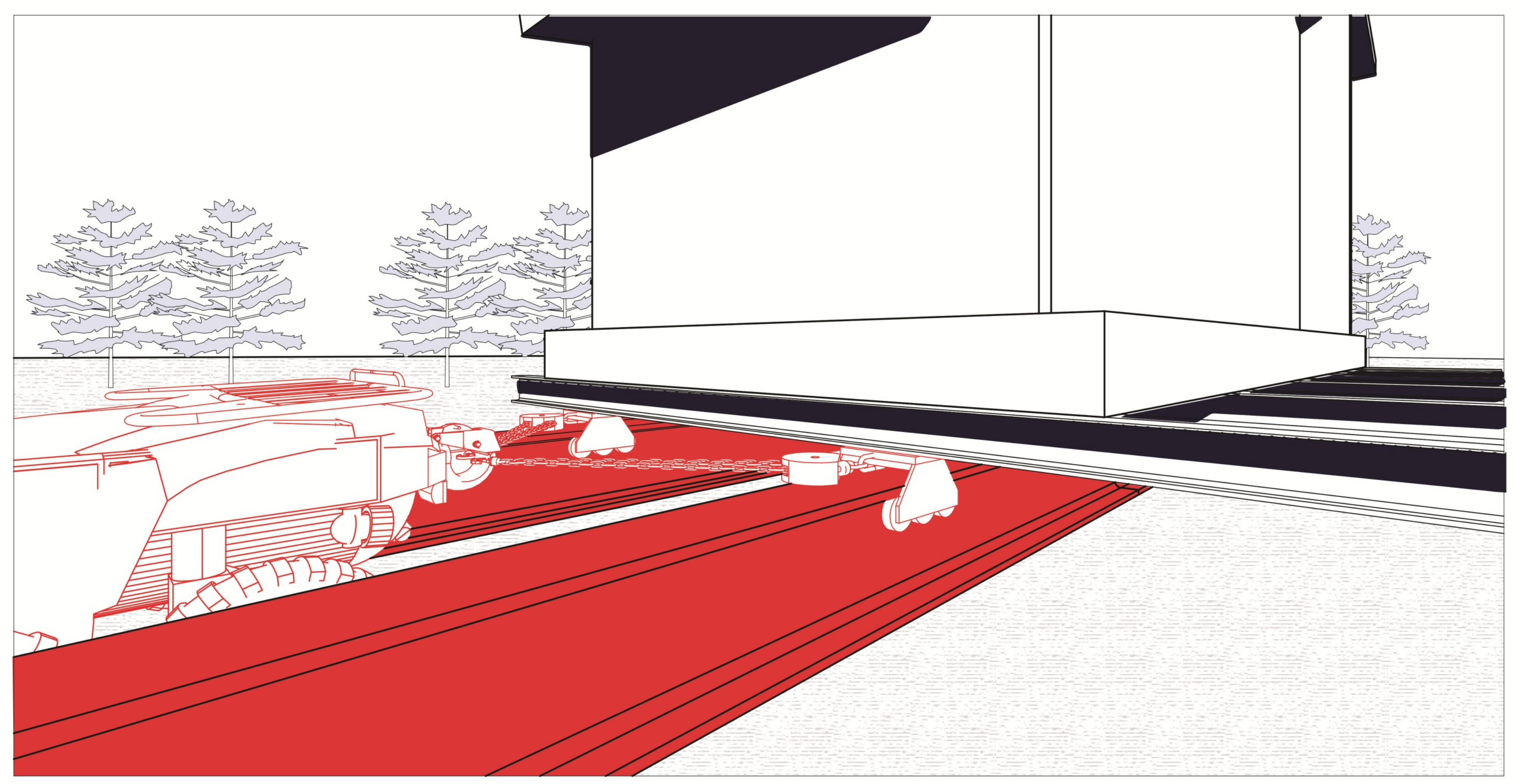




\section{CONCLUSION}

This thesis has questioned whether our dependence on our hardscaped river infrastructures such as dams and spillways and our current warning systems are sufficient means of protecting our communities in times of severe flooding. This thesis additionally investigated our current method of river data transmission, recognizing there is a delay in the delivery of flooding advisories to our coastal communities and there is a need to improve our current flood warning system. The proposal for the Flood Tower Network aims to break our dependency on prevailing water control infrastructure, by promoting a greater river awareness among communities; providing them the tools they require to act appropriately in the event of a flood. The Flood Towers are community tools -instruments of sorts - that generate an awareness of the dangers of rivers, while highlighting their beauty all at the same time. They provide a kind of prosthetic that is able to feel, engage with, and communicate the increasing dangers of a river. The tower is an architecture that allows people to come into direct contact with the river, physically drawing them into its center to see it and to know it. They act as a sort of "river museum", putting on display the dynamic — and often underestimatedpotential of the river. They double as an observation tower with an ascending stairway, wrapping around the flow tube, drawing people toward the top. Open to all members of the public, guests are invited to climb around the spine of the tower as they watch the rushing flow of the river ascending with them. Landings 
along the stairway offer moments for pause, allowing guests to consider, reflect, and question momentarily the forces of water at play around them. The amalgamation of historical structures — often rusted, decrepit, and abandoned used to build the body of the Towers, yield a somewhat ominous architectural structure. "Monsters are then infinitely obscure concepts, an offspring of the signs of presage and essentially related to architectural divination and demonstration. As with all signs, they project a world of the future." ${ }^{66}$ The Towers are not intended to be works of art or things of beauty, but rather are intended to capitalize on their disjointed nature to project a sense of wonder, or fear among communities who must start to question and respect the unpredictable forces of the river.

This thesis scrutinizes why developing communities continue to encroach along the edge of waterways, regardless of the undeniable risks associated with building in a floodplain. It was ascertained that dam operators and their built infrastructure have marginal control in mitigating coastal flooding. The proposal for the House Moving network draws attention to the fact that floods happen quickly and if communities are going to have a chance at mitigating damage, they will need to be able to relocate quickly. Reconsidering the concept of mobility and retreat will be crucial to alleviating property damage among our St. Lawrence and Ottawa river dwellers in the future. These two networks work together to serve as physical reminders of inundated villages of the past and serve as warnings to the lost villages of the future.

${ }^{66}$ Marco Frascari, Monsters of Architecture: Anthropomorphism in Architectural Theory, United Kingdom: Rowan \& Littlefield Publishers, 1990, 13. 
APPENDICES 


\section{APPENDIX A| MAPPING THE FLOOD}

The following section features a series of maps that narrate the hydrological network and flood statistics pertinent to understanding the compounding effects of the May 2017 flood of eastern Ontario and southern Quebec. To fully comprehend the historical magnitude of the flooding in May 2017, data was gathered from specific hydrometric data stations established along the St. Lawrence River and Ottawa River. The chosen gauging stations were situated near the Montreal and surrounding areas, as they are located in closest proximity to the epicenter and hardest hit regions of the flood.

\section{Map A: Hydrology and Data Stations}

At a scale of 1:100,ooo, map A visually combines the location of run-of-theriver control structures, hydrometric data stations and monthly precipitation data in the St. Lawrence drainage basin. In the early months of Spring, the total precipitation data for 150 hours from April 4th to 1oth was recorded across the basin. The map outlines the extents of the regions that received a combined total of more than 8omm of rain, which contributed to the severity of the increased water levels. Two power generating stations located at the final extents of both the Ottawa and St. Lawrence before their waters combine near the Montreal Harbour are shown. During the peak flow scenario experienced in May 2017, these generating stations — both of which are run-of-the-river control structures - 
released the maximum outflows ever recorded in the history of the St. Lawrence drainage basin. The Carillon Generating station spans the Ottawa River between Carillon and Pointe-Fortune, Quebec and has an annual flow variation of 1,0oo $\mathrm{m}^{3} / \mathrm{s}$ to 8, ooo $\mathrm{m}^{3} / \mathrm{s}$. A peak discharge and maximum daily flow of $8,862 \mathrm{~m} 3 / \mathrm{s}$ was observed on May 8th, 2017 "which was the highest ever recorded at that gauging station and coincides with literature for the time of the year when the greatest flood peaks occur." ${ }^{67}$ The Beauharnois generating station that spans the St. Lawrence between Beauharnois and Melocheville, Quebec has an annual flow rate of $6,000 \mathrm{~m}^{3} / \mathrm{s}$ to $9,000 \mathrm{~m}^{3} / \mathrm{s}$. Concurrently as the Carillon dam outflows were peaking on May 8th, the Beauharnois dam peaked its outflows at $10,400 \mathrm{~m}^{3} / \mathrm{s}$. Map A additionally indicates the location of both active and inactive hydrometric data stations dispersed throughout the St. Lawrence drainage basin that indicate river flow and water levels. The active gauging stations at Lake of Two Mountains, Ste Anne de Bellevue and Lake St. Louis [at Pointe-Claire] were chosen as sites for the new proposed Towers for their proximity to areas with the greatest flood damage. The stations experienced peak water levels of $24.77 \mathrm{~m}, 22.74 \mathrm{~m}$ and $22.58 \mathrm{~m}$ respectively, all well-above the $22.1 \mathrm{~m}$ flood alert level.

67 "Hydrological Analysis of the Historical May 2017 Flooding," McGill University. 


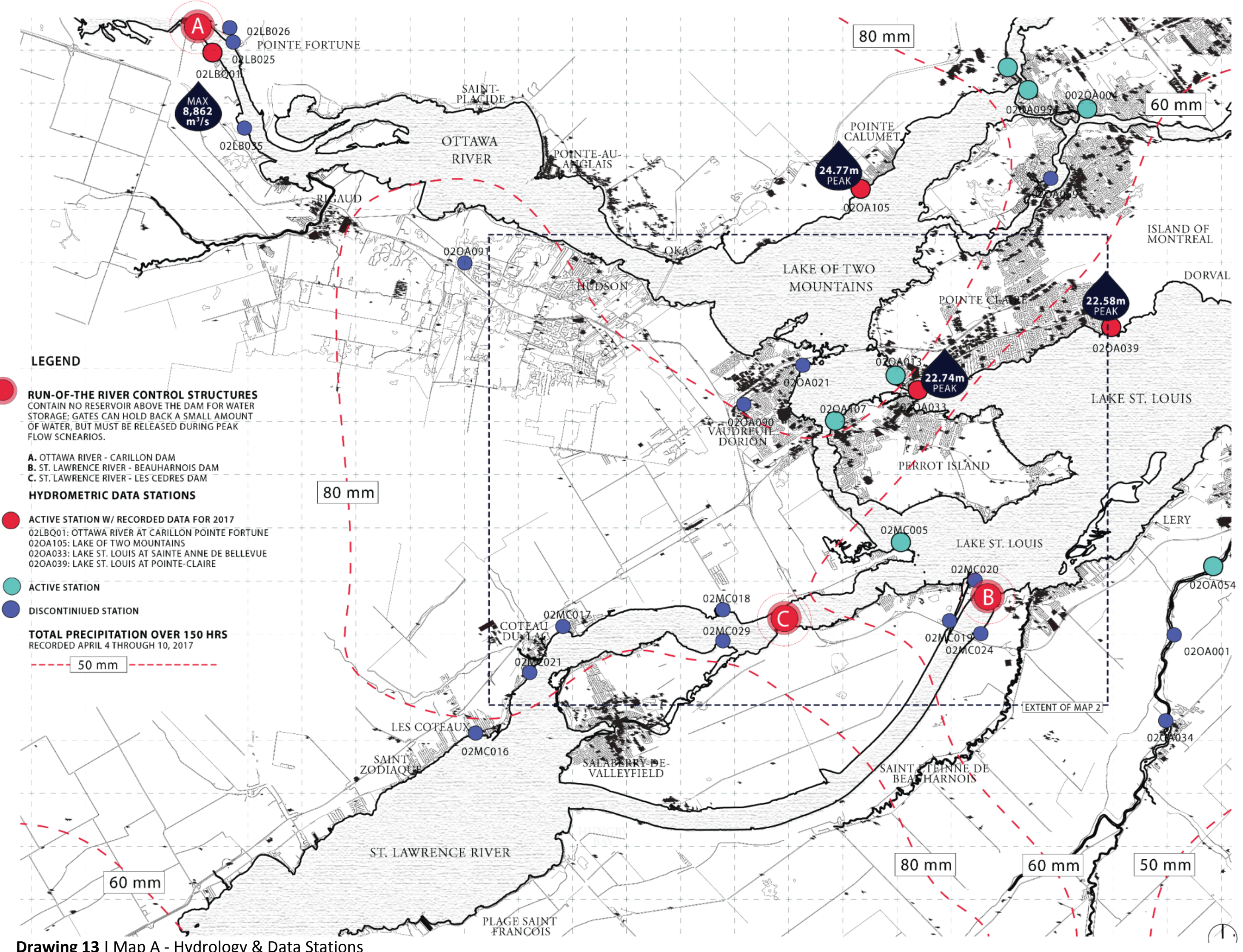

Drawing 13 | Map A - Hydrology \& Data Stations 


\section{Map B: Forecasted Flood Levels}

The second map in the series, at a scale of 1:50,00o visually displays the extents of floodplains in the St. Lawrence drainage basin. As an extension to map A, five hydrometric data stations (Carillon at Pointe-Fortune, Lake of Two Mountains, Pointe-Claire, Ste Anne de Bellevue, and Beauharnois) in the basin were chosen to display data for the maximum projected water levels for the 5,20 , 50 and 100 years return period flood. The data for the yearly return period floods are paired with data observed in 2017. At Carillon, right before the Ottawa River meets the St. Lawrence, "the flow rates corresponding to the 5, 20, 50 and 100 years return periods were all surpassed by the end of the first week of May 2017." ${ }^{68}$ As evidenced at all five locations, data gathered in 2017 surpassed the predicted levels for the 100-year flood, indicating the unreliability of data predicted for future events. The hydrometric data station at Lake of Two Mountains for example predicted a "10o-year flood" level of $24.4 \mathrm{~m}$, and in 2017 that level was surpassed by $40 \mathrm{~cm}$, peaking at $24.8 \mathrm{~m}$. The accumulated data at each location proves that predictions for the "1oo-year flood" can no longer be confidently used as the datum for flooding events.

Mapped as an area of inundated land, Map B outlines the extents of the "10o-year" floodplain (as can be seen in orange). The limits of the "1oo-year flood" are more severe and concentrated in specific regions along the St. Lawrence basin.

\footnotetext{
68 "Hydrological Analysis of the Historical May 2017 Flooding," McGill University.
} 
The map also indicates a larger area of inundated land superimposed on the "1ooyear" floodplain, referred to as Floodplain [U]. Floodplain (U)nknown, is a fabricated floodplain that refers to the indeterminable future limit of floodplain mapping. With the increasing unpredictability of climate change, it is becoming progressively more difficult to produce reliable flood maps. For the purpose of this thesis, the proposed Floodplain [U] was mapped based on two criteria. The extents were determined by both the elevational topography of the land and considered the most concentrated areas of inundated land as predicted by the "1oo-year" floodplain. The fictional, fabricated nature of Floodplain [U] highlights the reality that flooding is becoming increasingly more difficult to predict and we must begin shifting our reliance on predictions based on outdated data. 


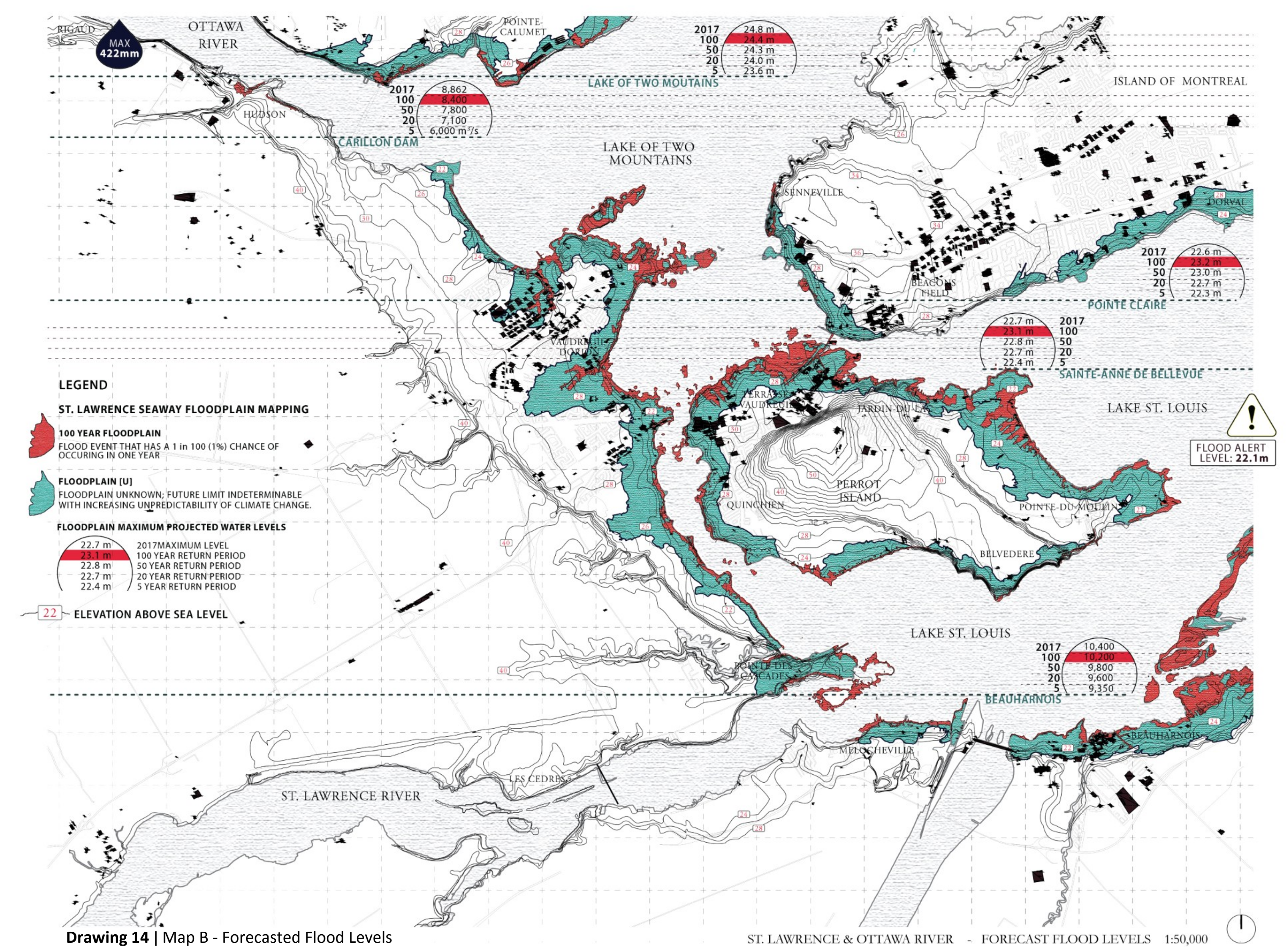




\section{Map C: Data Transmission Delay}

The third map in the series functions at a much larger scale, encompassing a longer stretch of the St. Lawrence River from Iroquois, Ontario down past the Montreal Harbour. The Water Survey Canada headquarters, situated on the western-most tip of Lake Ontario, can be seen on the lower edge of the map. The map features the relationship between the basin's hydrometric data stations and the amount of time required for their hydrographic data to be transmitted via satellite to the WSC headquarters. As was previously explained, there is upwards of a six hour transmission delay between the time the data is observed at the gauging stations and when the information is published online for public consultation. The accumulated time lag makes it more difficult for communities to be informed of the materialization of flood conditions in their area. The map also highlights the location of the proposed flood warning towers arranged along the St. Lawrence River from Iroquois, Ontario to Beauharnois, Quebec and the Ottawa River from Clarence-Rockland, Ontario to Hudson, Quebec. The flood warning towers are strategically placed based on an approximated $24 \mathrm{~km}$ visual radius perimeter. For the purpose of this thesis, it was assumed that each tower would stand roughly 4om high (an estimated average for the height of municipal water towers). Based on calculations used to determine the distance to the horizon based on a viewer's height above sea level, it was approximated that a $40 \mathrm{~m}$ water tower could be seen from a radial distance of $24 \mathrm{~km}$. The tower radii were superimposed to insure there 
were no gaps in visual coverage and all communities on the periphery of the river could see a warning tower. 


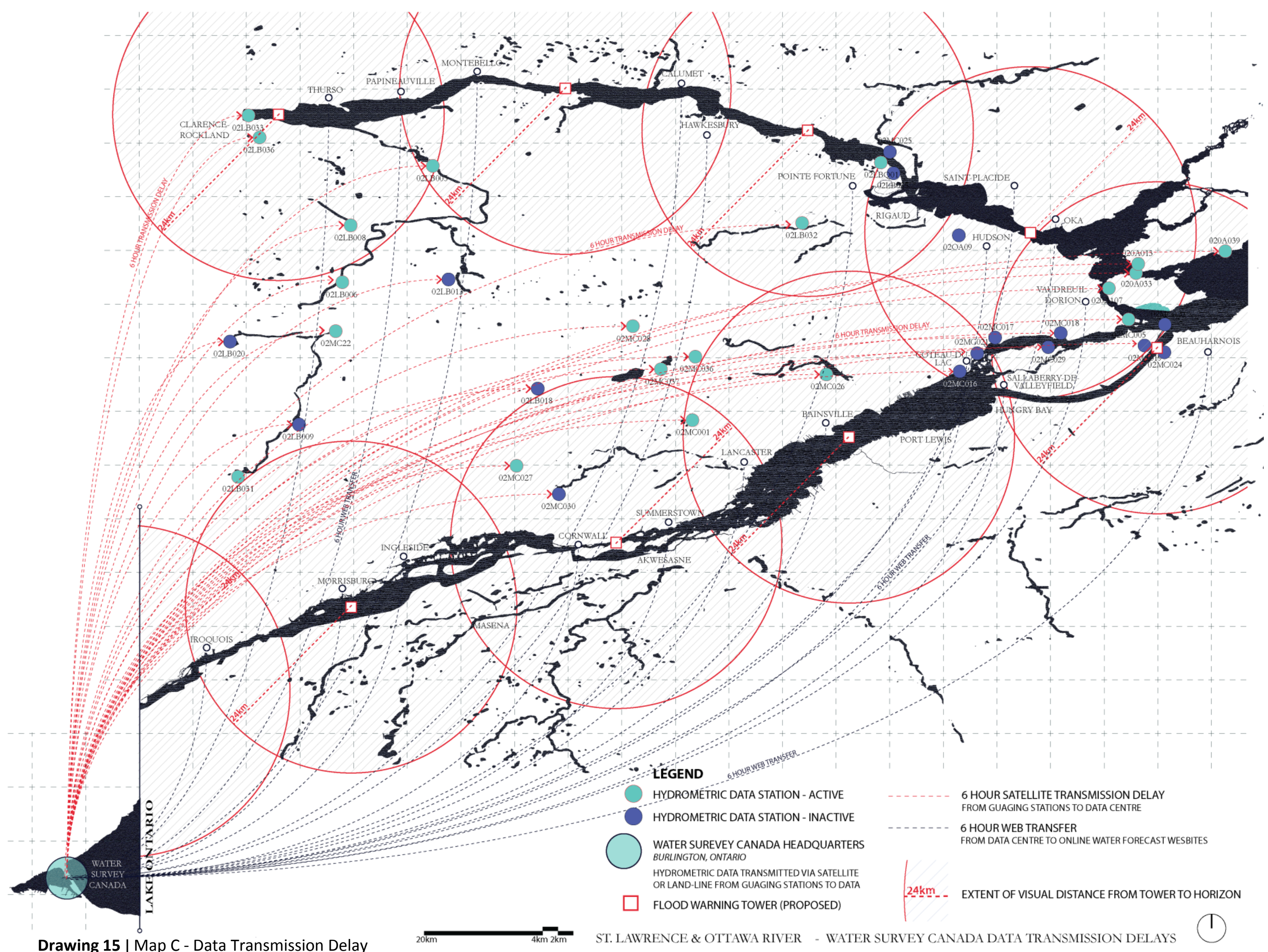




\section{APPENDIX B | RIVER CONTROL BOARDS}

\section{The International Joint Commission}

Canada and the United States share a border that runs along a major stretch of the upper extents of the St. Lawrence Seaway. The countries recognized that they are each affected by the other's actions in lake and river systems along their shared border, ${ }^{69}$ and the decision was made to create the International Joint Commission that would be the control board responsible for the cooperative management of the river system. The IJC is guided by the Boundary Waters Treaty that indicates general principles for preventing and resolving disputes between their shared waters. ${ }^{70}$ The Commission is responsible for approving projects relating to water levels and flows and recommending solutions to transboundary affairs. The IJC specify requirements for the outflows from Lake Ontario and the International Lake Ontario - St. Lawrence River Board's (ILOSLRB) main responsibility is to ensure the Moses-Saunders Power Dam are meeting these outflows.

The IJC are additionally responsible for communicating to the public about water levels and flow regulation along the seaway. ${ }^{71}$

\footnotetext{
${ }^{69}$ https://www.ijc.org/en/who/role

${ }^{70}$ https://www.ijc.org/en/who/role

71 "International Lake Ontario-St. Lawrence River Board,." International Joint Commission, https://ijc.org/en/loslrb
} 


\section{The Ottawa River Regulation Planning Board}

Established in 1983, The Ottawa River Regulation Planning Board (ORRPB) was established to ensure integrated management of the principal reservoirs of the Ottawa River basin. The Board's main purpose is to provide protection against flooding while maintaining all the interests of the various users of the water system. ${ }^{72}$ "There are a number of dams on the main stem of the Ottawa River from Timiskaming to Montreal, but they have very little storage capacity and generally pass whatever amount of water is coming down the river in periods of high flow."73 The Timiskaming reservoir, well-over 5ookm upstream of Montreal Harbour, is the last significant reservoir on the main stem of the Ottawa River. If the dam operators did not release an amount of water equal to the amount coming into the reservoir once it had reached capacity, the water would continue to rise, overtopping the walls of the dam, and would result in catastrophic damage to infrastructure and downriver communities. ${ }^{74}$

\footnotetext{
72 "Flooding FAQ," Ottawa River Regulation Planning Board, http://www.ottawariver.ca/flooding-faq.php

73 "Flooding FAQ," Ottawa River Regulation Planning Board.

74 "Flooding FAQ," Ottawa River Regulation Planning Board, http://www.ottawariver.ca/flooding-faq.php
} 


\section{APPENDIX C | GLOSSARY}

Encroachment: Activity within the floodway —-fill, new construction, substantial improvements, etc.

Flood fringe: Zone within a floodplain outside of the floodway; water is typically shallower and flows more quickly.

Floodplain: Flat land beside a lake or river, susceptible to flooding if any overflow occurs; part of a water's living space.

Floodway: Zone within a floodplain where floods are most destructive and the water flows fastest.

Littoral: relating to or situated on the shore of the sea or a lake; a region lying along a shore.

Riparian: relating to or situated on the banks of a river; relating to wetlands adjacent to rivers and streams.

\section{STRUCTURAL FLOODING MEASURES}

$\Rightarrow \mid \equiv \begin{aligned} & \text { Channel Improvements: Realignment to eliminate oxbows, bends, } \\ & \text { dredging, removal of debris, installation of weirs or drop structures, } \\ & \text { and provision of bank protection. }\end{aligned}$

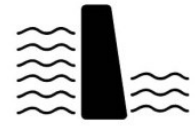

Dam: A Structure —earth, rock, concrete, or other material designed to retain water; retained in a pond, lake or reservoir.

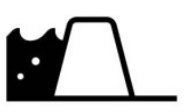

Dyke: Embankment constructed to protect low-lying areas from inundation by high water flows.

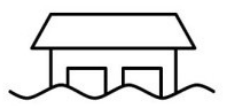

Floodproofing: Means of protecting built structures in the flood fringe from damage. 


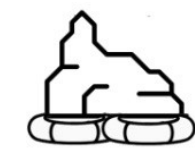

Ice booms: places across a river to prevent the downstream movement of ice, installed in the fall and removed after spring ice melt.

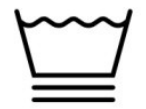

Storage: Artificial storage achieved through retention basins and storage reservoirs, or alteration of existing lakes.

\section{EMERGENCY FLOOD PROOFING METHODS}

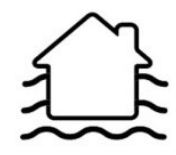

Dry flooding: The deliberate attempt to prevent water from ever reaching the structure; the most popular option when proper funds and time are available.

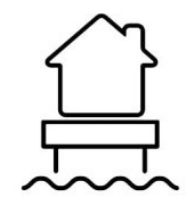

Elevation: Using piers, piles, columns, bearing walls or other built means to elevate the structure above the floodplain; requires careful design to prevent floating debris from damaging posts.

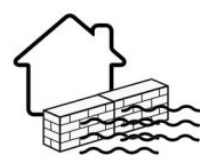

Floodwall: Construction of walls and berms intended to keep the structure dry without any modifications; requires no change to the building.

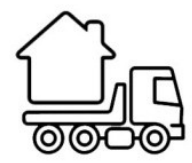

Relocation: Permanently relocating the structure outside of the floodplain by means of removal from the site.

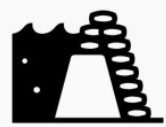

Sand Bagging: Bags filled with sand placed as a perimeter around structures to act as a barrier to divert incoming water around properties.

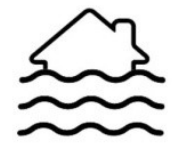

Wet flooding: The deliberate flooding of a structure to balance the water pressure on the interior and exterior walls and floors; often used as a last resort. 


\section{BIBLIOGRAPHY}

"About the Water Survey of Canada." Government of Canada. Last modified May 28, 2018. https://www.canada.ca/en/environment-climate change/services/water-overview/quantity/monitoring/survey/about.html

Allen, Laura and Smout, Mark. "Research Output 2: The Retreating Village." Published 2005. http://discovery.ucl.ac.uk/9740/1/9740.pdf

Butcher, Matthew. "A Lyrical Architecture of the Flood: Landscape, Infrastructure, and Symbiosis." In Arq: Architecture Research Quarterly: points of orientation dementia, ageing and the city infrastructures and affects, edited by Adam Sharr, 224-233. Cambridge: Cambridge University Press, 2015.

Coin, Glenn. "Meet the dams that control the fate of Lake Ontario and Montreal." last modified May 10, 2017.

https://www.newyorkupstate.com/weather/2017/o5/lake_ontario_montreal _flooding_st_lawrence_river_mos es-saunders.html.

"Disclaimer for Hydrometric Information." Government of Canada. Last modified December 10, 2018. https://wateroffice.ec.gc.ca/disclaimer_info_e.html

Environment Agency. "TE210o Plan Managing Flood Risk Through London and the Thames Estuary." Published November 2012. https://www.gov.uk/government/publications/thames-estuary-210o-te210o

"Flooding FAQ." Ottawa River Regulation Planning Board. http://www.ottawariver.ca/flooding-faq.php

"Floods: General Information." Government of Canada. Last modified December 2, 2010. https://www.canada.ca/en/environment-climatechange/services/water overview/quantity/floods/general-information.

Frascari, Marco. Monsters of Architecture: Anthropomorphism in Architectural Theory. United Kingdom: Rowan \& Littlefield Publishers, 1990.

"Frequently Asked Questions." Government of Canada. Last modified December 10, 2018. https://wateroffice.ec.gc.ca/contactus/faq_e.html

Godts, Marc and Janssens, Nel. "Theoretical, Conceptual, Ethical and Methodological Stakes to Induce a New Age: M. U. D.." In Architecture in the Space of Flows, edited by Andrew Ballantyne and Chris L. Smith, 43-61. Abingdon: Routledge, 2012. 
"Great Lakes - St. Lawrence River Adaptive Management (GLAM) Committee:

Summary of 2017 Great Lakes Basin Conditions and Water Level Impacts to Support Ongoing Regulation Plan Evaluation." International Joint Committee. Published November 13, 2018.

https://ijc.org/sites/default/files/2018-11/GLAM_2017_MainReport_FINAL20181129_2.pdf

Hardy, Dale. "General Archives: What am I." American Truck Historical Society. Posted March 7, 2011. http://forums.aths.org/PrintTopic111979.aspx

Hanania, Jordan, Stenhouse, Kailyn, \& Doney, Jason. "Pelton Wheel." Energy Education. Last updated September 3, 2015. https://energyeducation.ca/encyclopedia/Pelton_turbi ne_turbine

Holmes, Robert R. Jr. "The 10o-Year Flood - It's All About Chance." United States Geological Survery (USGS). https://water.usgs.gov/edu/10oyearfloodbasic.html

"How the Dutch Make 'Room for the River' by Redesigning Cities" Higher and higher dykes will not keep the waters at bay under climate change." Scientific American. Published on January 20, 2012. https://www.scientificamerican.com/article/how-the-dutch-make- roomfor-the-river/

"Hut on Sleds." Crosson Architects. http://crosson.co.nz/hut-on-sledswhangapoua/

Hutchinson, Bruce. The Unknown Country (1942), quoted in Warkentin, So Vast and Various, 129-31.

International Joint Commission. "Lake Ontario St. Lawrence River Plan 201: Protecting against extreme water levels, restoring wetlands and preparing for climate change." Published June 2014. https://ijc.org/sites/default/files/Plan\%202014\%2oEN.pdf

"International Lake Ontario-St. Lawrence River Board." International Joint Commission. https://ijc.org/en/loslrb

"International Lake Ontario-St. Lawrence River Board: Observed Conditions and Regulated Outflows 2017." International Joint Commission. Published May 25, 2018. https://www.ijc.org/sites/default/files/2018 o8/ILOSLRB_FloodReport2017.pdf. 
J'arry, Alfred- Selected Works. R. Shattuck and S. W. Taylor, eds. .London: 1965Johnson, Mark, and Lakoff, George, Metaphors We Live By. Chicago: Chicago University Press, 1980.

Macfarlane, Daniel. Negotiating a River: Canada, the US, and the Creation of the St. Lawrence Seaway. Vancouver: UBC Press, 2014.

Marsh H., James \& Baker, Nathan. "Ottawa River." The Canadian Encyclopedia. Last edited November 30, 2018. https://www.thecanadianencyclopedia.ca/en/article/ot tawa-river

Marsh H., James. "St. Lawrence River." The Canadian Encyclopedia. Last edited March 4, 2015. https://www.thecanadianencyclopedia.ca/en/article/st -lawrence-river

McGrath, Matt. "Sea surrender plan to ease flood fears on south coast." BBC News. Published November 4, 2013. https://www.bbc.com/news/scienceenvironment-24770379

Meyer, Carl. "The dam at the heart of Canada's flooding emergency." Canada's National Observer. Published May 4, 2017. https://www.nationalobserver.com/2017/05/04/news/d am-heart-canadasflooding-emergency.

"National Weather Service Marine Forecasts: Coastal Warning Display Program." National Oceanographic and Atmospheric Administration. Last modified November 18, 2014. https://www.nws.noaa.gov/om/marine/cwd.htm

O'Flaherty, Rosemary. "Lost Villages." The Lost Villages Historical Society. https://lostvillages.ca

Pallardy, Richard. "Semaphore Communications." Encyclopaedia Britannica. https://www.britannica.com/technology/semaphore

Permansingh, Jafaun. "Hydrological Analysis of the Historical May 2017 Flooding Event in Montreal and Surrounding Areas." BREE 631: IWRM Internship Project, McGill University, 2017.

Perreaux, Les. " What did we learn from 2017's floods in Quebec and Ontario? Inside the politics of water." The Globe and Mail. Published January 5 , 2018. https://www.theglobeandmail.com/news/national/quebec-ontariofloods-water- management-politics/article37511432/ 
Phillips, David. "Canada's Top Ten Weather Stories 2017." Canadian Meteorological and Oceanographic Society. Published January 7, 2018.

https://bulletin.cmos.ca/canadas-top-ten-weather-stories-2017/

"Rotameters: Introduction to flow Measurement with Rotameters." Omega. Published August 8, 2018. https://www.omega.ca/en/resources/rotameters

"Sled House: A House You Can Relocate With a Tractor?" Lunchbox Architect. https://www.lunchboxarchitect.com/featured/sled-house/

Soucy, Paul. "Lost Villages of the St. Lawrence River: Canada's Atlantis." Global News. Published August 8, 2018. https://globalnews.ca/news/436962o/lostvillages-of-the-st-lawrence- river-canadas-atlantis/

Thomas, Lowell J., The Story of the St. Lawrence Seaway, (Buffalo, New York: Stewart, 1957).

"Water survey of Canada and provincial/territorial flood information." Government of Canada. Last modified January 11, 2017.

https://www.canada.ca/en/environment- climate-change/services/wateroverview/quantity/monitoring/survey/provincial-territorial-floodinformation.html

"What the Dutch Can Teach the World About Managing Floods." CBC Radio. Published September 3, 2017. https://www.cbc.ca/radio/thesundayedition/the-sunday-editionseptember-3-2017-1.4265299/what-the-dutch-can-teach-the-world-aboutmanaging-floods-1.4270589

White, Richard. The Organic Machine: The Remaking of the Columbian River (New York: Hill and Wang, 1995); Cioc, The Rhine.

Wheeler, Maggie. "The Lost Villages." The Canadian Encyclopedia. Published September 29, 2014. https://www.thecanadianencyclopedia.ca/en/article/the-lost-villages

White, Richard. The Organic Machine: The Remaking of the Columbia River. (New York: Hill and Wang, 1995), as quoted by Daniel McFarlane in Negotiating a River.

Williams, Lauren, Harrison, Simon, and O'Hagan, Anne Marie. "The Use of Wetlands for Flood Attenuation." Report for An Taisce by Aquatic Services Unit, University College Cork, 2012. 
Yates, Amanda. "Oceanic Spaces of Flow." In Architecture in the Space of Flows, edited by Andrew Ballantyne and Chris L. Smith, 63-80. Abingdon: Routledge, 2012. 